\title{
THE LATE PLEISTOCENE PO RIVER LOWSTAND WEDGE IN THE ADRIATIC SEA: CONTROLS ON ARCHITECTURE VARIABILITY AND SEDIMENT PARTITIONING
}

\author{
Claudio Pellegrini ${ }^{1}$, Alessandra Asioli ${ }^{1}$, Kevin M. Bohacs $^{2}$, Tina M. Drexler ${ }^{3}$, Michael L. \\ Sweet $^{2}$, Vittorio Maselli ${ }^{4}$, Marzia Rovere ${ }^{1}$, Fabiano Gamberi ${ }^{1}$, Giacomo Dalla Valle ${ }^{1}$, Fabio \\ Trincardi $^{1}$
}

( $^{1}$ ) Istituto di Scienze Marine (ISMAR-CNR), Via Gobetti 101, 40129, Bologna, Italia

$\left({ }^{2}\right)$ ExxonMobil Upstream Research Company, 22777 Springwoods Village Parkway, Spring, TX 77389, U.S.A

$\left(^{3}\right)$ ExxonMobil Exploration Company, 22777 Springwoods Village Parkway, Spring, TX 77389, U.S.A

$\left({ }^{4}\right)$ Department of Geology and Petroleum Geology, University of Aberdeen, King's College, Aberdeen, UK

\begin{abstract}
Although the facies and stratal geometries of continental margin successions can be defined in detail based on subsurface and outcrop studies, most documentations lack the high-resolution age control needed to constrain their timing and infer their external forcing mechanisms. The 350-mthick Po River Lowstand Wedge (PRLW) preserves a high-resolution record of stacked deltaic clinothems deposited during the Last Glacial Maximum (LGM) in the Adriatic basin (Mediterranean Sea). We investigated clinothem internal geometry, stacking patterns, and facies distributions to infer the main controls on their growth by integrating seismic reflection data with seismic facies attributes. The stratigraphic framework of the clinothems was then related to major paleoenvironmental shifts driven by the last glacial cycle and associated eustatic and climatic changes. This framework is well constrained by geochronological dates based on ${ }^{14} \mathrm{C}$ and tephra recognition.
\end{abstract}

Within the PRLW, three distinctive types of clinothems, Type A, Type B and Type C, each with diagnostic topset geometries, shelf-edge trajectories, and associated basinal deposits: Type A clinothems display moderate topset aggradation, ascending shelf-edge trajectories, and Mass- 
Transport Complexes (MTCs) in the slope-basin; Type B clinothems have eroded topsets, descending shelf-edge trajectories, and Distributary Channel-Lobe Complexes (DLCs) in the slopebasin; and Type $\mathrm{C}$ clinothems show pronounced topset aggradation, ascending shelf-edge trajectories and fine-grained concordant strata in the slope-basin. The clinothem types also show systematic variations in sediment accumulation rates as well as in their individual areal distribution and extent. In particular during the last glacial maximum, clinothem accumulation rates were as much as $200 \mathrm{~km}^{3} / \mathrm{ky}$ (in some of the Type B clinothems). Changes in sediment export to the basin correlate with the distance of the clinothem shorelines from the shelf-edge: when the distance is less than $5 \mathrm{~km}$, topset degradation coupled with direct sediment bypass to the basin promoted the formation of DLCs (Type B clinothems), and when that distance was more than $10 \mathrm{~km}$, no direct conduit linked the shelf to the slope and no significant volume of coarser-grained sediment reached the basin floor (Type C clinothems).

The elementary clinothem types stack into two Clinothem Sets. Clinothem Set 1, with essentially flat to slightly descending shelf-edge trajectory, is composed of stacked A and B clinothems, and records the direct influence of river flux (maximum during the deposition of Type B clinothems) leading to dysoxic conditions on the bottom of the basin. Clinothem Set 2, showing ascending shelf-edge trajectory, records an aggradational stacking coupled with a retreat of the river-entry points with benthic fauna assemblages that reflect the influence of peaks in fresh water discharge. Whereas Clinothem Set 1 developed under perturbations of river supply linked to the multi-scale waxing-waning of glaciers during an interval dominated by eustatic fall, Clinothem Set 2 reflects the main thawing of glaciers during the first phase of the eustatic rise.

Borehole calibration of the grid of seismic profiles indicates that the entire PRLW accumulated in $17 \mathrm{ky}$, with individual clinothems representing intervals that range from 400 to 4,700 years. The high-resolution age control enabled us to relate stratal character to independently constrained environmental parameters; this revealed how the evolution of a margin-scale system 
intricately convolves the influences of both global (eustacy) and regional (climate-driven supply

fluctuations) controls. Finally, the thickness, geometry, and stacking patterns of the PRLW clinothems vary in systematic ways resulting in geometries that closely resemble those of ancient shelf-edge systems, and offering the PRLW as a modern analogue. By recognizing the very shorttime interval associated with the deposition of each type of clinothem we question if, in ancient records, clinothems with a putative duration of hundreds of thousands of years might record instead much shorter intervals with most of the geological time condensed in hiatuses and stratigraphic surfaces. We suggest that the PRLW provides valuable insight into the lower end of the possible range of time spans recorded by such ancient margin-scale clinothems. Our observations also reinforce the focus of the classic sequence-stratigraphic approach on analyzing surfaces and their geometric relations and not on time duration or formation mechanisms.

\section{INTRODUCTION}

Shelf-margin wedges and associated clinothems are the critical link between continental and deep-water realms and a distinctive record of the growth of continental margins. Although localized, on a global scale they have an outsized importance and their strata have been estimated to sequester $>40 \%$ of the biogenic carbon in the modern ocean and to host $>40 \%$ of global oil reserves, including many important recent discoveries (e.g., Suter and Berryhill, 1985; Walsh, 1991; Sydow et al., 2003; Muller-Karger et al., 2005; IEA, 2013). Detailed analyses of the stratigraphic record in shelf-margin settings can provide useful insights on their response to external and internal forcing mechanisms on time scales longer than available in weather- and oceanographic-instrument records. Therefore the characterization of clinothem evolution within high-resolution chronostratigraphic contexts is a fundamental aid in the prediction of hydrocarbon reservoir potential and in the reconstruction of continental-margin history and controls (e.g. eustasy and climate). In this view, sequence stratigraphy is a method through which a systematic analysis of the 
stratigraphic record can help in reconstructing the evolution of continental margins in time and 2008; Fatoke and Bhattacharya, 2010; Bhattacharya et al., 2016) and their response to cyclic autogenic and allogenic controls (e.g. Muto and Steel et al., 1997; Jerolmack and Paola, 2010; Madof et al., 2016). Focused initially on million-years time scales (Mitchum et al., 1977), sequence stratigraphy has long since been applied to the study of Quaternary continental margins at Milankovitch-band time scales (mostly at 100,000 year scale). At all scales, accommodation and sediment supply are recognized as the main factors that govern changes in stratal architecture and sediment partitioning across continental margins (e.g. Trincardi and Field, 1991; Pillans et al., 1998; Roberts et al., 2004; Jouet et al., 2006: Ridente et al., 2009; Fatoke and Bhattacharya, 2010; Anderson et al., 2016; Amorosi et al., 2016).

In the study of continental margins, clinothems have been documented as one of the fundamental building blocks of the stratigraphic record (Asquit, 1970; Helland-Hansen and Martinsen, 1996; Pirmez et al., 1998; Steel et al., 2000; Pellegrini et al., 2017). Clinothems have been recognized over several spatial and temporal scales ranging from shoreline accretion to continental-margin progradation (Vail et al., 1991; Steckler et al., 1999; Swenson et al., 2005; Carvajal et al., 2009; Helland-Hansen and Hampson, 2009; Patruno et al., 2015; Pellegrini et al., 2015) and are sensitive archives of climate and oceanographic regime (e.g. Cattaneo et al., 2003; Swenson et al., 2005; Fanget et al., 2014; Pellegrini et al., 2015; Tesi et al., 2017).

By studying the anatomy of a 350-m-thick shelf-margin wedge deposited during a single short-lived lowstand of sea level, we document, in a chronologically well-constrained framework (Pellegrini et al., 2017), a composite succession of late-Pleistocene clinothems recording short-term (sub-Milankovitch-scale) environmental and climatic change during the Last Glacial Maximum (LGM). Particular attention has been paid to the characterization of 1) the 3D shape of individual margin-scale clinothems (100s m thick; up to $5 \mathrm{~km}$ of progradation) and their thickness distribution 
as a function of the Sediment Accumulation Rate (SAR) and accommodation; 2) the vertical and lateral distribution of sedimentary facies; 3) the timing of and controls on the activity of deep-water channel-lobe complexes.

These results have been combined with a well-constrained suite of paleo-environmental proxies with the aim of testing some of the key concepts typically adopted in the reconstructions of recent and ancient progradational margins. We thus are able to correlate our observations on clinothem development with a suite of environmental parameters to assign stratigraphic variations to their possible causes. The main goal of this paper is to illustrate how the growth of this sediment wedge was controlled by the intricate interactions of climatic variations and eustatic oscillations that largely impact on sediment-supply fluctuations and the character of sedimentation in the different sectors of a prograding margin. Finally, we highlight the role of sub-Milankovitch cyclicity in controlling the stacking pattern of clinothems and clinothem sets even down to centennial- to millennial-scale variations in the rates of sediment supply and fresh-water discharge and accompanying environmental changes.

\section{SETTING}

\subsection{Geological evolution of the Adriatic foredeep}

Following the early Alpine compression that led to the closure of the Tethys in the late Cretaceous (Doglioni, 1994), the Mediterranean region was characterized by a compressive regime affecting the Apennine mountain chain starting in the Oligocene. During the lower Pliocene, the eastward migration of the Apennine front induced the tilting of the Adriatic foreland toward the orogenic front, causing the formation of foredeep depocenters of variable-thickness and their subsequent infill through Quaternary prograding sequences along the axis of the basin (Royden et al., 1987; Dalla Valle et al., 2013a, 2013b; Ghielmi et al., 2013; Rossi et al., 2015). 
In the north-central Adriatic basin, the most recent southeastward prograding sequence (Fig. 1), is of late Pleistocene age (Trincardi et al., 1994). The late Pleistocene succession encompasses the eustatic lowstand of the Last Glacial Maximum (LGM; Fig. 2), when the Po River Lowstand Wedge (PRLW) recorded a $40 \mathrm{~km}$ shelf-edge progradation (Pellegrini et al., 2017; Fig. 3) partially filling the Mid Adriatic Dip (MAD), a remnant slope basin that was few hundred meters deep. During the deposition of the PRLW, most of the underlying tectonic structures became inactive (Fig. 4); however, localized active geological structures, possibly related to halo-kinetic deformation of Triassic evaporates, punctuate the eastern sector of the MAD (Geletti et al., 2008).

\subsection{Adriatic basin physiography from the Last Interglacial to Last Glacial Maximum times}

During the last previous interglacial (Marine Isotope Stage 5e, 132-116 ky BP, Bazin et al., 2013) the physiography of the Adriatic basin was similar to the modern one, with a shoreline somewhat landward of the modern position (Amorosi et al., 2004). The ensuing step-wise lowering of sea level between oxygen-isotope Substage 5e and 2 (ca. 11.7 ky BP, Walker et al., 2009; Fig. 2), promoted a marked basinward shift of the shoreline and the formation of a regionally-extensive unconformity associated with alluvial-plain sedimentation in the northern, shallower reaches of the basin (Amorosi et al., 2016). From land to basin, the succession of MIS 3 and MIS 2 is identified as: 1) paleosols and associated channel-belt deposits in the northern and southern Adriatic coastal plain (Amorosi et al., 2017; Campo et al., 2017); 2) an extensive hiatal surface across a significant portion of the area presently occupied by the modern shelf (Amorosi et al., 2016); and 3) a thick sedimentary succession that fills in the MAD (Fig. 3), recording glacio-eustatic oscillations at Milankovitch and sub-Milankovitch scales (Piva et al., 2008a; Pellegrini et al., 2017). In essence, the interval between the MIS 5e and the onset of the LGM (at ca. $26 \mathrm{ky}$ BP) spanned a substantial shrinking of the Adriatic basin and the concurrent broadening of the Po plain drainage area with a stepwise displacement of the shoreline up to ca. $250 \mathrm{~km}$ southeastward (Amorosi et al., 2016), and a 
relative sea level position at ca. $130 \mathrm{~m}$ lower than present day (e.g. Lambeck et al., 2014; Benjamin et al., 2017). During that time interval, extensive glaciers capped the Alpine chain (Florineth and Schluchter, 1998; Monegato et al., 2007, 2017) nourishing the ancestral Po River system which debouched into the central Adriatic slope basin promoting the formation of the PRLW during overall cold climatic conditions (Fig. 2; Pellegrini et al., 2017).

\subsection{Sediment supply: modern and inferred for the Last Glacial Maximum}

The modern Adriatic basin is fed mainly by Alpine and Apennine Rivers, while the sediment yield from the Dinarides is negligible because of the intensely fractured and karstic nature of the catchments that trap water and sediment influx in basins close to the coastal area (Simeoni et al., 1997; Milliman and Farnsworth, 2013; Del Bianco et al., 2014). Fluvial sediment sources along the western side of the Adriatic Basin form a "line source", with combined modern delivery of $51.7 \times$ $10^{6}$ tons $\mathrm{yr}^{-1}$ of mean suspended load and an average freshwater discharges of $1500 \mathrm{~m}^{3} \mathrm{~s}^{-1}$ (Frignani et al., 2005; Cattaneo et al., 2003; Milliman et al., 2016). In contast, during the LGM the drainage system of the ancestral Po River was more than double its current size, reaching about $190,000 \mathrm{~km}^{2}$, compared to the modern catchment of $94,000 \mathrm{~km}^{2}$ (Kettner and Syvitski, 2008). The estimated average suspended sediment flux into the Northern Adriatic Sea during the Pleistocene is estimated to have been $46.6 \times 10^{6}$ tons $\mathrm{yr}^{-1}$, with an average freshwater discharge of $3000 \mathrm{~m}^{3} \mathrm{~s}^{-1}$, from the Po River alone (Kettner and Syvitski, 2008).

\section{DATA, METHODS, AND STRATEGY}

\subsection{Seismic data, borehole and sediment cores}

The main set of reflection-seismic profiles used for this work was acquired during the LowStand Delta (LSD) 2014 cruise and was shot using a mini water-gun source (Sercel S15-02 of $15 \mathrm{inc}^{3}$ ) and recorded through a multichannel streamer (Teledyne mini-streamer with 24 channels; 
80-500 Hz frequency band width) complemented by single-channel profiles shot with a 300-J

Sparker electro-mechanic source and by a dense grid of CHIRP sub-bottom lines with a $2-7 \mathrm{kHz}$ outgoing signal. All data were digitally recorded after band-pass filtering and gain adjustment. The seismic grid comprises high-resolution seismic profiles with a total length of $1500 \mathrm{~km}$ and covers an area of $5000 \mathrm{~km}^{2}$ centered in the MAD (Fig. 1). In addition, a multibeam bathymetry of the MAD was acquired using a Kongsberg EM710 hull-mounted multibeam and gridded at $20 \mathrm{~m}$ resolution.

The seismic grid has been tied to the PRAD1-2 borehole (Pellegrini et al., 2017), a $71.2 \mathrm{~m}$ long borehole with a total recovery of $99.6 \%$ sampled in 185.5 m water depth (Fig. 1). Seismicstratigraphic correlation from the expanded stratigraphic clinoform succession to the distal borehole is straightforward, and was corroborated for the upper ca. $80 \mathrm{~m}$ of the succession by correlation through a network of CHIRP sonar profiles. Key stratigraphic surfaces of regional extent are tied to PRAD1-2 borehole with a vertical resolution of 0.3-0.5 m (Fig. 5).

The PRAD1-2 borehole and two other sediment cores were analyzed in detail for micropaleontological analyses to form a composite biostratigraphic section. Sediment core CM9243 is located at $252 \mathrm{~m}$ water depth at the bottom of the slope basin, and sediment core PAL94-8 is at $150 \mathrm{~m}$ water depth close to the shelf-edge (Trincardi et al., 1996). The chronology of these two cores, already published by Asioli (1996) and Asioli et al. (2001), is here partially revised for the interval older than $15 \mathrm{ky}$ BP (Tab. 1; see supplemental material).

\subsection{Seismic Interpretation and Analysis}

We conducted seismic-stratigraphic interpretation and then seismic-facies analyses with that stratigraphic framework to delineate genetically related strata and infer depositional conditions. The interpretation of seismic profiles was based on the principles of seismic stratigraphy (Mitchum et al., 1977; Mitchum et al., 1991), and the accommodation-succession method (Neal and Abreu, 
2009; Neal et al., 2016). Following these approaches, which use reflection terminations as the

principal criteria for the recognition of seismic sequence boundaries, the sequence boundary $(\mathrm{SB})$ at the base of the PRLW was identified on the shelf by toplap and onlap terminations of respectively the underlying and overlying reflections (angular unconformity of Mitchum et al., 1977), and traced basinward to a correlative conformity with onlap and downlap terminations of the overlying reflections (Figs. 6 and 7; Pellegrini et al., in press). The maximum regression surfaces (MRS), atop the PRLW, separates progradational-aggradational stacking from retrogradational stacking of coastal transgressive strata on the shelf (see Pellegrini et al., 2017) and corresponds with a marine onlap surface of limited extent on the slope (according to the definition by Catuneanu et al., 2009).

Within the PRLW, we recognized three types of clinothems based on topset geometry, shelfedge- and onlap-point-trajectory, and internal seismic facies (Pellegrini et al., 2017). Seismic-facies analysis is the description, mapping, and geologic interpretation of seismic-reflection parameters within a chronostratigraphic framework of sequence boundaries (after Mitchum et al., 1977). We delineated the external form, internal reflection characteristics, and 3-D associations of the stratal units within the larger seismic-stratigraphic framework to assure the identification and correlation of genetically related strata. Reflection configuration reveals gross stratification patterns from which depositional processes and erosion can be interpreted. Reflection continuity is closely associated with continuity of strata; continuous reflections suggest widespread, uniformly stratified deposits. Reflection amplitude contains information on the velocity and density contrasts of individual bedding interfaces and their spacing. It is used to predict lateral bedding changes. Reflection spacing ('frequency'), although mainly a characteristic of the seismic pulse, is also related to geologic factors such as the spacing of reflectors and lateral changes in interval velocity (due to lithofacies and pore-fluid changes). Grouping these seismic parameters into mappable seismic-facies facilitates their interpretation in terms of lithotype, depositional processes and environment, possible sediment entry-point locations, and geological setting. Within the PRLW 
distinctive seismic facies are grouped into 11 generic subclasses (Table 2). The criteria we used to distinguish different facies included seismic-reflection amplitude, continuity, and dip (where dipping reflections are $>0.8^{\circ}$ ), internal reflection character, and the nature of their boundaries, as well as their position in the depositional system (Table 2 and Fig. 6).

Trajectory analysis considers lateral and vertical migration of geomorphological features and associated sedimentary environments, with emphasis on the paths and direction of migration of the coastal onlap and correlative shelf-edge (Steel et al., 2000; Henriksen et al., 2009 and reference there in). We conducted shelf-edge trajectory analysis in due consideration of the fact that the rollover point (offlap break of Vail et al., 1977 and Jervey, 1988) at the topset-foreset transition of a clinothem can occur in shelfal marine environments and thus might not necessarily represent the shoreline (i.e., the shelf-edge rollover point, at best, only approximates the shoreline position: see Pellegrini et al., 2015 and discussion therein). Key stratigraphic surfaces of regional extent and seismic facies (Table 2) were recognized, correlated, loop-tied, and mapped using Petrel® software. The maps of these key stratigraphic surfaces were constructed by using a "convergent interpolation" method. A seismic velocity of $1600 \mathrm{~m} / \mathrm{s}$, as suggested by the sonic-log analyses (Maselli et al., 2010), was adopted to convert two-way travel times (TWTT) into depth units and to calculate the volume of seismic units.

The nature of the key surfaces and the reflection configurations of the clinothems were then combined with the timing of their formation to examine the relative roles of controlling factors on deposition and sediment distribution such as eustasy and sediment supply. For each clinothem, the progradation and the Sediment Accumulation Rate (SAR) are given as horizontal migration and vertical thickness, respectively, at the corresponding shelf-edge divided by their time-duration.

\subsection{Analyses of micropaleontology}


Planktic and benthic foraminifera concentrations are expressed as number of specimens per gram of dry sediment, whereas the species are expressed as percentages. Globigerinoides sacculifer includes Globigerinoides trilobus, Globigerinoides quadrilobatus and Globigerinoides sacculifer according to Hemleben et al. (1989). The category "warm planktic species" in figure 8 includes species that preferred warm waters, such as Globigerinoides ruber, Globoturborotalita rubescens, Globigerinoides tenellus, G. sacculifer, Globigerinella praecalida, Orbulina universa (Pujol and Vergnaud-Grazzini, 1995).

Among the benthic foraminifera, the "deep-infaunal" group mainly comprises the benthic species Glandulina laevigata and, occasionally, by Fursenkoina, a taxon adapted to a deep infaunal microhabitat and especially resistant to low-oxygen conditions (Jorissen, 1993, 1999). Glandulina laevigata is reported as very rare in biocenosis restricted to Arctic (Knudsen, 1971, Murray, 2013), Atlantic and Indian oceans with highest abundances in slightly hypersaline Arabian Gulf shelf (Murray, 2013). Here we tentatively include this taxon in the deep-infaunal community on the basis of its great morphological affinity with the taxa, including Glandulonodosariidae, that went extinct during the Last Global Extinction (Pliocene-Mid Pleistocene Transition, see Hayward et al., 2012 for more details), whose habitat was infaunal with enhanced food supply and consequent low oxygen concentrations, as suggested by geochemical analyses $\left(\delta^{13} \mathrm{C}\right)$.

\subsection{Age control}

The timing of the clinothems of the PRLW was derived from the chronology of the borehole PRAD1-2 analyzed in detail by Pellegrini et al. (2017) for the time interval MIS 3-MIS 2, with 106 samples counted for foraminiferal content through a ca. $16.5 \mathrm{~m}$ thick succession (regarding the sample preparation and the counting method the reader is referred to Piva et al., 2008a). The agemodel relies on a quantitative assessment of the variations in relative abundance of the diverse foraminifera species, stable isotope records, ${ }^{14} \mathrm{C}$ AMS dates, and tephrochronology on macro and 
cryptotephra (Bourne et al., 2010), as well as on bioevents and event-stratigraphy (Fig. 5 and Table $1)$.

\section{RESULTS}

\subsection{Chronology of the PRLW}

The base (SB) and the top (MRS) of the PRLW cross the PRAD1-2 borehole at $14.6 \mathrm{~m}$ (bmsl) and $2.5 \mathrm{~m}$ (bmsl), respectively, bracketing the entire PRLW between 31.8 cal. ky BP and 14.4 cal. ky BP (Fig. 5; Pellegrini et al., 2017). The chronological data indicate therefore that the PRLW represents an expanded stratigraphic succession that developed in solely ca. $17 \mathrm{ky}$ (achieving up to $350 \mathrm{~m}$ of thickness) during the latest phase of sea level fall, the LGM sea level lowstand, and the early phase of sea level rise (Figs. 2 and 5).

\subsection{Micropaleontology 31.8-14.6 ky}

Due to favorable conditions of accommodation and sediment supply, middle Pleistocene regressive successions are exceptionally expanded in the Central Adriatic (Trincardi and Correggiari, 2000; Ridente and Trincardi, 2005; Ridente et al., 2009), and the MIS 5e-MIS 2 interval (late Pleistocene), in particular, preserves a nearly continuous record of a fourth-order (100 kyr) stepwise sea level fall (Amorosi et al., 2016). Starting from the SB at $31.8 \mathrm{ky}$ BP the PRLW succession shows four intervals that are characterized by distinct foraminifera assemblages (Fig. 8):

Interval 1 (31.8 to 24.7 ky BP: Type $\mathrm{A}_{1}$ - $\mathrm{A}_{2}$; Fig. 8). Both planktic and benthic foraminifera are present, although planktic foraminifera are more scarce (even one order of magnitude in some intervals). The planktic assemblage is largely dominated by Turborotalita quinqueloba and occasionally by Globigerina bulloides. At $28.2 \mathrm{ky}$ BP (corresponding ca. to e1 surface), the concentration of planktic foraminifera shows an abrupt decrease. The benthic assemblage is largely 
dominated by Cassidulina carinata, except during the pronounced inflection between 30.2-28.2 ky

BP, where $C$. carinata is replaced by miliolids and later by Hyalinea balthica. Deep infaunal taxa are rare and below $10 \%$ of abundance.

Interval 2 (24.7 to 19.2 ky BP: $\mathrm{B}_{2}-\mathrm{A}_{5}$; Fig. 8). Planktic-foraminifera abundance and benthic concentration show an upward decreasing trend, starting from $21 \mathrm{ky}$ (close to $\mathrm{A}_{3}-\mathrm{B}_{3}$ clinothem boundary). This interval is characterized by closely spaced fluctuations in the abundance of $C$. carinata and includes the continuous occurrence of Nonion depressulus and Nonion pauciloculum, whereas deep infaunal taxa peak only at the base of the interval. The planktic assemblage is similar to the previous Interval 1 .

Interval 3 (19.2 to 18.0 ky BP: $\mathrm{B}_{5}-\mathrm{A}_{6}$; Fig. 8). The concentration of both planktic and benthic foraminifera decrease further and the $C$. carinata abundance drops to zero. $N$. pauciloculum and $N$. depressulus show abundances similar to the previous interval, as well as deep infaunal taxa, always present although with low frequency.

Interval 4 (18.0 to $14.6 \mathrm{ky} \mathrm{BP:} \mathrm{C}_{1}-\mathrm{C}_{2}$; Fig. 8). During this interval the concentration of planktic and benthic foraminifera reaches a minimum compared to the rest of the PRLW, and especially the planktic component drops close to zero ( 2 specimens per gram on average, mainly belonging to $T$. quinqueloba). $N$. pauciloculum and $N$. depressulus makes up to the $80 \%$ of the foraminifera assemblage. This turnover of the benthic assemblage is accompanied by a marked increase of deep infaunal taxa.

\subsection{Seismic facies description and inferred depositional environments}

The most striking feature seen on dip-oriented seismic lines (Figs. 3 and 6) are the southward dipping and hundred-meter thick clinothems. The internal architecture of these clinothems changes in a repeated way that consists of a common suite of seismic facies that have been interpreted as clues to the sedimentary processes that shaped the clinothems. 
Topset seismic facies (HAC, HACh, HAD)

The topsets of all three types of clinothems are characterized by High Amplitude Continuous reflectors (HAC) that change laterally to High Amplitude Chaotic reflectors (HACh). The latter are discontinuous, irregular reflections (Table 2). At the modern seafloor, High Amplitude Discontinuous reflections (HAD) characterize deposits with irregular spatial distribution.

\section{Topset inferred depositional environment}

The topset seismic facies are interpreted as coastal-plain deposits: HAC are interpreted as delta plain sandy-silty deposits that change laterally to HACh reflections interpreted as amalgamated fluvial channel belts with sandy-muddy fill (Table 2). At the modern seafloor, HAD reflections characterize lagoon deposits formed behind highly discontinuous and reworked barrier features with sparse distribution as documented by earlier publications (Trincardi et al., 1994; Storms et al., 2008).

\section{Upper foreset seismic facies (HAChDip-HACDip-HACWDip-LACDip)}

Foresets are characterized by a variety of seismic facies: High Amplitude Chaotic Dipping reflections (HAChDip), High Amplitude Continuous Dipping reflections (HACDip) and Low Amplitude Continuous Dipping reflections (LACDip) are present in the topset-foreset transition sector of clinothems. Locally, parallel to wedge-shaped high-amplitude reflection packages pass laterally to low-amplitude reflections that characterize sediment strata up to several ten of meters thick (Fig. 9). In addition, packages up to 10-m-thick composed of High Amplitude Continuous Wavy and Dipping reflections (HACWDip; Table 2), characterize the clinothems developed in the western sector of the MAD. 


\section{Upper foreset inferred depositional environment}

Located seaward from the coastal-plain and channel-belt deposits, HAChDip reflections suggest the presence of distributary channels that extended over the shelf-edge and in the upper slope (Table 2). The HACDip and LACDip reflections are interpreted as heterolithic foreset deposits, related to the delta front and prodeltaic zone. Locally, wedge-shaped reflections indicate the presence of channel-levee systems several tens of meters thick acting as a major conduits of sediment bypass from the shelf to the basin (Fig. 9). Finally, the HACWDip reflections include 10m-scale crenulated features resembling those documented on several late-Holocene prodelta deposits (see Urgeles et al., 2011 and references therein).

\section{Lower foreset-bottomset seismic facies (SHAM-DLAH-HLAC)}

Three characteristic seismic facies developed in the transitional area between foreset and bottomset. Semi-Continuous High Amplitude Mounded reflections (SHAM), Discontinuous Low Amplitude reflections with internal Hyperbolic diffractions (DLAH), and High- and LowAmplitude Continuous reflections (HLAC). The first two seismic facies characterize clinothems developed during the first phases of PRLW progradation and highlight up to $45 \mathrm{~ms}$ thick basin deposits (Tab. 2 and Fig. 6). The latter seismic facies is associated with clinothems developed in the late phase of the PRLW progradation (Fig. 6).

\section{Lower foreset-bottomset inferred depositional environment}

The SHAM, DLAH, and HLAC seismic facies are interpreted as prodeltaic-deep-marine facies. In particular, SHAM and DLAH are interpreted, based on their close resemblance to corecalibrated seismic facies found in basin-floor fan deposits in the Gulf of Mexico (Beaubouef and 
Friedmann, 2000), as Distributary channel-Lobe Complexes (DLCs), and as Mass Transport Complexes (MTCs), respectively. HLAC seismic facies suggest the presence of concordant heterolithic strata in the younger clinothems (Fig. 6).

Bottomset seismic facies (HLAC)

At the basinward end of clinothems High- and Low-Amplitude Continuous reflections (HAC and LAC) characterize the sedimentary packages (Fig. 6).

\section{Bottomset inferred depositional environment}

This facies has been calibrated by extensive coring results as representing muddy basinal facies with black fine-grained intercalations (Trincardi et al., 1996; Piva et al., 2008a, b). Fairly continuous (but variable rate) sedimentation promoted continuous bottomset aggradation also in the easternmost portion of the PRLW (Gallignani-Pelagosa sector; Fig. 4).

\subsection{Evolution of the PRLW}

\subsubsection{The Mid Adriatic Deep 31.8 cal. ky BP (SB surface) and the PRLW total thickness}

At $31.8 \mathrm{ky} \mathrm{BP}$, the MAD was a semi-elliptical slope basin about $45 \mathrm{~km}$ by $40 \mathrm{~km}$ wide with a maximum paleo-depth of ca. $450 \mathrm{~m}$ (Pellegrini et al., in press; Fig. 10). The gently dipping shelf passed into a slope dipping about $1^{\circ}$, and to a pronounced bowl-shaped topography in the central sector of the basin, which hosted a central NNE-SSW anticline structure named in the following MAD anticline (Fig. 10). The PRLW accumulated in the MAD reaching $350 \mathrm{~m}$ in thickness $(>400$ ms; Fig. 10) for a total accumulation of $504 \mathrm{~km}^{3}$.

\subsubsection{Clinothem characterization}


Within the PRLW we recognize three types of elemental clinothems based on their geometry and seismic facies. The elemental clinothems are separated by key regional surfaces named "e" and "s" surfaces whose character, significance, and dating are described in detail in Pellegrini et al. (2017). Type A clinothems show topset aggradation, typically $10 \mathrm{~m}$ at the shelf-edge, over an average distance of $10 \mathrm{~km}$; Type B clinothems, in contrast, do not display topset aggradation and show a maximum distance of less than $5 \mathrm{~km}$ between the shelf-edge and correlative onlap point where the "e" surface merges with the underlying "s" surface; Type C clinothems show maximum topset aggradation of up to $20 \mathrm{~m}$ thickness over an average distance of $20 \mathrm{~km}$ and the maximum horizontal distance between the shelf-edge and the time-equivalent shoreline. The 3 clinothems types are 64 to $160 \mathrm{~m}$ thick and have basinward dips of up to $2.1^{\circ}$ (Fig. 6). The character of each type of clinothem is reported in the following paragraphs and summarized in Table 3, where average shelf-edge progradation and foreset inclination for each clinothems is also provided.

The types of clinothems are systematically stacked with Type A and B clinothems that constitute Clinothem Set 1 , characterized by a flat/slightly falling shelf-edge trajectory and a shelfedge progradation of ca. $30 \mathrm{~km}$; Type $\mathrm{C}$ clinothems constitute Clinothem Set 2, showing an ascending shelf-edge trajectory and a shelf-edge progradation of ca. $10 \mathrm{~km}$ (Fig. 6). Altogether, the shelf-edge through Clinothem Set 1 and 2 prograded a total of $40 \mathrm{~km}$.

The following paragraphs describe the key features of each clinothem in the PRLW, highlighting their bounding surfaces and ages, paleobathymetry at their base (inferred from its basal structure map), map pattern of sediment accumulation, and lateral distribution of seismic facies and inferred depositional environments. These factors, along with sediment accumulation rates and environmental changes are summarized in Table $4 \mathrm{a}, \mathrm{b}$. A detailed description of the older Clinothem $A_{1}$ is followed by shorter descriptions of the succeeding clinothems, highlighting the main changes through time. 
Clinothem $A_{1}$ (SB-s1 surfaces: $31.8-29.4$ ky BP)

The structural map of the base of Clinothem $\mathrm{A}_{1}$ (Fig. 11a) shows the MAD antiform striking NNW-SSE, extending from the shelf edge to the base of the slope and separating the MAD in two sub-basins. The thickness map shows the main depocenter reaching the maximum thickness, of 110 $\mathrm{m}$, on upper slope, just westward of the MAD antiform. Clinothem $\mathrm{A}_{1}$ extends distally over ca. 40 $\mathrm{km}$ pinching out at the southern edge of the MAD basin (Fig. 11b). The seismic facies map (Fig. 11c) shows the extent of the HACh topset facies that corresponds with amalgamated channels on a large coastal plain located landward of the shelf-edge both NW of the MAD (Po plain channel belt) and WSW of it (Apennine Rivers channel belt). The foreset is dominantly characterised by HAChDip corresponding with a channelized prodelta. The bottomset is characterised by DLAH reflections indicating the presence of Mass Transport Complexes (MTCs). The MTCs are confined east of the MAD antiform and lap onto the southern margin of the basin. The distal seismic facies in the toe of the foreset is characterised by HAC reflections that are the evidence of fine-grained deposition.

Clinothem $B_{1}$ (s1-el surfaces: 29.4-28.4 ky BP)

The structural map of surface s1 (Fig. 12a) indicates that the MAD antiform still maintained a morphological expression at the sea floor in the basin and at the shelf-edge. The main depocenter of Clinothem $\mathrm{B}_{1}$ is located just east of the MAD antiform. In addition, the $\mathrm{B}_{1}$ depocenter (Fig. 12b), being restricted to the northern edge of the MAD basin, has a smaller areal extent than that of the underlying Clinothem $\mathrm{A}_{1}$; the lack of $\mathrm{B}_{1}$ clinothem on the shelf shows that no aggradation occurred during its deposition. The proximal bottomset is characterized by SHAM reflections ascribed to Distributary Channel-Lobe Complexes (DLCs; Fig. 12c).

Clinothem $\mathrm{A}_{2}$ (e1-s2 surfaces: 28.4-24.7 ky BP) 
The structural map of surface e1 (Fig. 13a) shows an area of minimum depth corresponding to the NNE-SSW MAD antiform. The thickness map (Fig. 13b) shows a main depocenter located on the eastern slope and extensive aggradation on the shelf resulting in an overall linear progradation of the eastern sector of the MAD. The seismic facies distribution of Clinothem $\mathrm{A}_{2}$ (Fig. 13c) shows the occurrence of DLAH reflections of MTCs in the eastern reaches of the MAD, as in the previous $\mathrm{A}_{1}$ clinothem.

Clinothem $B_{2}$ (s2-e2 surfaces: 24.7 and 24.2 ky BP)

Structural map of s2 surface (Fig. 14a) suggests that the underlying MAD antiform was not completely buried after the deposition of previous clinothems. The sediment-thickness map (Fig. 14b) shows a main depocenter striking WSW-ENE on the upper slope with Clinothem $\mathrm{B}_{2}$ thicker and more extensive along the shelf-edge compared to the underlying Clinothem $\mathrm{A}_{2}$. The seismic facies map (Fig. 14c) denotes SHAM reflections of DLCs as in the preceding Type $\mathrm{B}_{1}$ clinothem.

\section{Clinothem $A_{3}(e 2-s 3$ surfaces: 24.2-21.1 ky BP)}

The structural map of the e2 surface (Fig. 15a) shows a deeper sub-basin in the western sector compared to the eastern sector. The thickness map of Clinothem $A_{3}$ (Fig. 15b) shows two main coalescing depocenters developed on the upper slope. In the distal sector, Clinothem $\mathrm{A}_{3}$ is characterized by digitate external geometries. Distally, Clinothem $\mathrm{A}_{3}$ reflects the structural confinement exerted by structure on southern rim. The seismic facies map (Fig. 15c) shows LACDip and DLAH reflections of muddy prodelta and MTCs respectively, down in the bottomset sector whereas the distal area is characterized by LAC reflections of fine-grained deposits- $\mathrm{a}$ distinct change from the HAC reflections in the underlying clinothems.

Clinothem $B_{3}$ (s3-e3 surfaces: 21.1-20.6 ky BP) 
The structural map of surface s2 (Fig. 16a) shows a deeper sub-basin in the western compared to the eastern sector. The thickness map (Fig. 16b) reveals coalescing individual depocenters that define an external geometry elongated along the E-W axis of the basin. In the toeset sector, Clinothem $\mathrm{B}_{3}$ shows a digitate external geometry and reflects the structural confinement exerted by the southern flank of the basin. The seismic facies map (Fig. 16c) is characterized by SHAM reflections ascribed to DLCs.

\section{Clinothem $\mathrm{A}_{4}($ e3-s4 surfaces: 20.6-19.4 ky BP)}

The structural map of e3 surface (Fig. 17a) shows the presence of a deeper sub-basin in the western sector. The thickness map (Fig. 17b) shows a main depocenter on the slope that extends mainly in the western sub-basin reflecting the structural confinement at the toe of clinothem. The seismic facies map of Clinothem $\mathrm{A}_{4}$ (Fig. 17c) shows a bottomset characterised by DLAH reflections ascribed to the presence of MTCs with an erratic distribution.

\section{Clinothem $B_{4}$ (s4-e4 surfaces: 19.4-19.3 ky BP)}

The structural map of Clinothem $\mathrm{B}_{4}$ (Fig. 18a) shows a linear shelf-edge and a quasi-buried MAD antiform in the slope sector. The thickness map (Fig. 18b) highlights an elongated depocenter in the central part of the slope characterized by a digitate external geometry in the distal sector. Clinothem $\mathrm{B}_{4}$ contains HACh and HAChDip reflections that are the evidence of amalgamated channels on the northern foreset which pass laterally to SHAM reflections (DLCs) in the foreset and bottomset.

\section{Clinothem $A_{5}($ e4-s5 surfaces: $19.3-19.0 \mathrm{ky} \mathrm{BP})$}

The structural map of surface e4 (Fig. 19a) indicates that the NNW-SSE MAD antiform still had a morphological expression in the bottomset sector. The thickness map (Fig. 19b) shows a 
maximum thickness at the foreset/bottomset transition represented by coalescent depocenters with

no digitate pattern. The seismic facies map (Fig. 19c) reveals HAC reflections that indicate, for the first time during the PRLW progradation, the presence of delta-plain deposits in the western sector, along with $\mathrm{HACh}$ reflections with locally isolated incised valleys containing internal oblique reflections (Fig. 9). The foreset sector in the western sub-basin is characterized by HACDip reflections of heterolithic prodelta. Basinward the presence of DLAH reflections are the evidence of MTCs; these distibution of MTCs appears to have been confined structurally.

\section{Clinothem $B_{5}$ (s5-e5 surfaces: 19.0-18.6 ky BP)}

The structural map of surface s5 at the base of the unit (Fig. 20a) shows an irregular shelfedge with a prominent bulge in the centre of the study area. The thickness map (Fig. 20b) highlights two main coalescing depocenters extending to the upper slope in the western sub-basin. The map of the seismic facies (Fig. 20c) highlights the replacement of MTDs (LACH) with DLCs (SHAM) and of HAC with LAC reflections in the proximal and distal bottomset, respectively, compared to the underlying $\mathrm{A}_{5}$ clinothem.

Clinothem $A_{6}($ e5-s6 surfaces: $18.6-18.0 \mathrm{ky} \mathrm{BP})$

The structural map of the basal surface e5 (Fig. 21a), shows a bulge at shelf-edge with an indentation in the eastern sub-basin, possibly suggesting a sector of slope instability. The thickness map (Fig. 21b) highlights elliptical depocenter in western sub-basin and an elongated depocenter in the eastern one. The seismic facies map (Fig. 21c) shows LACDip reflections of muddy prodelta characterize the foreset/bottomset sector. In the eastern sub-basin and at the toe of the clinothem, DLAH reflections indicate the presence of MTCs.

Clinothem $C_{1}$ (s6-s7 surfaces: 18.0 and $\left.15.8 \mathrm{ky} \mathrm{BP}\right)$ 
The structural map (Fig. 22a) indicates an irregular shelf-edge and shows the presence of a deeper sub-basin in the western sector. The thickness map (Fig. 22b) shows aggradation in the topset sector and a depocenter elongated in an E-W direction on the upper slope. In the western subbasin, where Clinothem $\mathrm{A}_{6}$ reaches the maximum thickness, the deposit tends to adapt to the structural confinement. The seismic facies map (Fig. 22c) shows HACh reflections that pass to HAC reflections suggesting the confinement of amalgamated channels in the western topset. On the foreset, Clinothem $\mathrm{C}_{1}$ shows a variety of seismic facies from LACDip to HACWDip reflections reminiscent of muddy to sandy prodelta deposits that locally are characterized by crenulation features (sensu Urgeles et al., 2011).

\section{Clinothem $C_{2}$ (s7-MRS surfaces: 15.8-14.4 ky BP)}

The structural map (Fig. 23a) is characterized by the presence of a quasi-linear shelf-edge and two sub-basins with similar depth in the eastern and western sector of the MAD. The main subrounded depocenter is in the foreset/bottomset sector of the western sub-basin (Fig. 23b) and a widespread area of topset aggradation on the north-western shelf. The seismic facies map (Fig. 23c) highlights the presence of HAC reflections of delta-plain and distal deposits that occupy a broad sector of the depositional area.

\subsubsection{The Mid Adriatic Deep: modern configuration}

The modern bathymetry is characterized by a straight $35-\mathrm{km}$ shelf edge in the north, a western slope sector characterized by slope-parallel bedforms, and a narrow 254-m deep slope-basin bounded to the east and to the south by the complex Gallignani-Pelagosa relief of tectonic origin. The multibeam data (Fig. 10) document a widespread field of pockmarks (Fig. 24), confirming the escape of fluids through the underlying units (Hovland and Curzi, 1989; Trincardi et al., 2004; Geletti et al., 2008). 
A comparison of the modern bathymetry with the paleobathymetry of the MAD at $31.8 \mathrm{ky}$ $\mathrm{BP}$, reveals the macro changes of the basin configuration that occurred mainly through the progressive southward shift of the northern rim of the basin, reflecting $40 \mathrm{~km}$ progradation of the shelf-edge (Fig. 24). Conversely, the configuration of the southern boundary of the basin remained substantially fixed, reflecting an area of fine-grained sediment aggradation. As a consequence, the basin size shrunk from ca. 3500 to $1600 \mathrm{~km}^{2}$ (this measure is taken comparing the areas surrounded by the $200 \mathrm{~m}$ bathymetric contour at $31.8 \mathrm{ky} \mathrm{BP}$ and today).

\section{DISCUSSION}

\subsection{History of the PRLW: patterns, influences, and controls}

The development of the PRLW occurred in four main phases recorded by integrated changes in stratal-stacking patterns, shelf-edge trajectory, map-pattern distribution of sediment accumulation, character of the strata within the clinothems, and basin environmental conditions. These phases appear to be closely related to changes in both accommodation and sediment supply, as influenced by pre-existing bathymetry, eustasy, oceanographic conditions, and global and regional climate. Oceanographic conditions of importance to stratal character included salinity, temperature, turbidity, nutrient availability, and dominant energy mode (waves, river, or tides). Integration of the broad range of controls and influences reveals the genesis of the stratal patterns and enables appropriate use of the PRLW as an analog for prediction of rock properties in ancient systems. The following section discusses the main patterns, influences, and controls of each phase of development of the PRLW. Table $4 \mathrm{a}$ and $\mathrm{b}$ presents details of each clinothem and associated paleoenvironment regime, respectively. The following section combines, for each phase, information on the stratal patterns with environmental information. 
For completeness, we briefly describe the strata that occur below the basal sequence boundary (SB): The stratigraphic unit below SB has been interpreted as a regressive succession of subaqueous muddy clinothems that accumulated on the shelf under the influence of along-shore sediment transport during the last phase of the Pleistocene eustatic fall (Trincardi and Correggiari, 2000; Ridente and Trincardi, 2005; Ridente et al., 2009). These subaqueous muddy clinothems were probably genetically related to subaerial progradation nourished by the ancestral Po River (Pellegrini et al., in press). This interpretation is supported by the overall external geometry of this unit, its seismic facies, and the location of the shoreline during its deposition $(>15 \mathrm{~km}$ from the shelf-edge). Reflections in the uppermost part of this unit show truncation and toplap terminations at the overlying SB. The microfaunal assemblages recorded in the PRAD1-2 borehole below SB confirm an outer shelf paleoenvironment with bottom waters relatively well oxygenated and warm surface waters characterized by winter mixing during the early phase of MIS 3 (59-40 ky BP; Piva et al., 2008b). This condition evolves after $40 \mathrm{ky} \mathrm{BP}$ into a shallower (mid-shelf) environment with progressively colder, more productive and stratified surface waters (Piva et al., 2008b). The overlying strata of the Phase 1 interval lap onto the SB (Pellegrini et al., in press).

\subsubsection{Phase 1: basal Sequence Boundary (SB) to $\mathbf{s 2}$ (clinothems $A_{1}$ to $A_{2}$ ), 31.8 to $24.7 \mathrm{ky} B P$}

Patterns: The strata between surfaces SB and s2 comprise two Type A and one Type B clinothems that stack in an overall progradational pattern. The shelf-edge trajectory evolves from flat to slightly ascending to slightly descending. In plan view, sediment accumulation evolves from a radial pattern restricted to the central outer shelf with compensational stacking of clinothems $A_{1}$ and $B_{1}$, to linear progradation in the eastern slope area in Clinothem $A_{2}$ (Figs. 11-13; Tab. 4a). The upstream (topset) region is interpreted to have been a broad coastal plain with amalgamated channel belts of the Po River (more preserved from the NW) and the Apennine rivers (less preserved from the WSW) converging to the Mid-Adriatic Dip (MAD). The foreset region was a channelized sandy 
prodelta environment. The proximal bottomset region includes stacks of Mass-Transport

Complexes (MTCs in $\mathrm{A}_{1}$ and $\mathrm{A}_{2}$ ) and Distributary Channel-Lobe Complexes (DLCs in $\mathrm{B}_{1}$ ), while the distal bottomset area accumulated conformable fine-grained strata.

Influences and controls: At the onset of the deposition of Phase 1 clinothems the basin morphology was influenced by the presence of the MAD antiform that extended SSE from the shelf-edge to the base of the slope. This antiform separated the MAD into two sub-basins that are prominent at the base of the interval, but progressively more subdued upward. Eustasy fell by $45 \mathrm{~m}$ to $125 \mathrm{~m}$ below present-day sea level quite rapidly at the beginning of this phase $\left(\mathrm{A}_{1}\right)$, and continued to fall, but more slowly during the upper two-thirds of this phase ( $\mathrm{A}_{2}$; Lambeck et al., 2014). This fall corresponds globally to the end of Dansgaard-Oeschger Interstadial 5 (based on lighter $\delta^{18} \mathrm{O}$ values and an abundance peak of warm planktic species at this level in the PRAD1-2 borehole), followed by a phase of rapid and continued growth of the Laurentide and European ice sheets (Dyke et al., 2002; Boulton et al., 2001). Sediment supply rates to the basin increased significantly at the base of the interval, and decreased towards the top by a factor of 5; sediment accumulation rates vary from 27.5 to 44 to $9 \mathrm{~km}^{3} / \mathrm{ky}$ upward in the three $\mathrm{A}_{1}, \mathrm{~B}_{1}$, and $\mathrm{A}_{2}$ clinothems, respectively (Tab. 4b). Regionally, the Apennine glaciers were advancing throughout Phase 1, with Alpine glaciers starting their advance slightly later, during $\mathrm{A}_{2}$ time (Fig. 8; Tab. 4b; Giraudi, 2017; Monegato et al., 2017).

The planktic assemblage, not abundant, indicates that surface waters were cold and biogenically productive; (Hemleben et al., 1989; Pujol and Vergnaud-Grazzini, 1995), at least far from direct riverine influence, as suggested by the dominance of the opportunistic benthic foraminifera species C. carinata (Fig. 8; Tab. 4b; Van der Zwaan and Jorissen, 1991, Mojthaid et al., 2009, Goineau et al., 2011). Bottom waters appear to have been relatively well oxygenated, with organic matter being decreasingly well preserved upward (Fig. 8). This interpretation is based on the peaks of the epifaunal/shallow infaunal foraminifer $H$. balthica that suggest relatively well- 
oxygenated bottom water and/or a lowering of the quality of the organic matter (Schmiedl et al., 2000, Hess and Jorissen, 2009, Murray, 2006, Sweetman et al., 2009). Starting abruptly from 28.2 ky BP (corresponding ca. to the e1 surface, Fig. 8) conditions became less favorable, in particular for the intermediate-water dweller G. bulloides (much less abundant from this level upward) driven by a progressive decrease of the water depth (Fig. 8). This shift matches the beginning of the Global LGM, coeval with Greenland Stadial 3 (27.540-23.340 ka) and encompasses the global sea-level lowstand (Hughes and Gibbard, 2015).

\subsubsection{Phase 2: s2-s5 (clinothems $B_{2}$ to $A_{5}$ ), 24.7 to $19.0 \mathrm{ky} \mathrm{BP}$}

Patterns: The strata between surfaces s2 and s5 comprise three Type A as well as three Type B clinothems that stack in an overall progradational pattern. The shelf-edge trajectory alternated between descending in Type B clinothems to slightly ascending in Type A clinothems. In plan view, sediment accumulation evolves from three main radial depocenters on the slope of $\mathrm{B}_{2}$ clinothem to elliptical depocenters slightly elongated W-E and with a digitate map pattern. For the first time since the PRLW progradation began, clinothems depocenter started to reflect a structural confinement against the distal limit of the basin (southern rim). In addition, $\mathrm{A}_{4}-\mathrm{B}_{4}-\mathrm{A}_{5}$ clinothems are reduced in thickness and extent compared to the previous couplets, and show clear compensational patterns (Figs. 17-19; Tab. 4a). The topset region is interpreted to have been a broad coastal plain with amalgamated channel belts of the Po River (to the NW) and the Apennine rivers with occasionally-preserved delta plain sandy-silt deposits converging to the MAD. In the topset and upward, clinothems deposits evolve from amalgamated channel-belt deposits $\left(\mathrm{A}_{3}\right.$ clinothem; Fig. 25), to isolated incised valleys with internal point-bar migration that suggest a switch of the fluvial systems to more sinuous, meandering patterns ( $\mathrm{A}_{5}$ clinothem; Fig. 25). In the foreset area, large-scale turbidite slope channel-levee complexes covered by mud wedges $\left(\mathrm{B}_{2}\right.$ clinothem; Fig. 25) record the closest linkage of the shelf to the basin during the entire PRLW 
progradation. The proximal bottomset alternated between Mass-Transport Complexes (MTCs in $\mathrm{A}_{3}$, $\mathrm{A}_{4}$, and $\mathrm{A}_{5}$ ) and Distributary Channel-Lobe Complexes (DLCs in $\mathrm{B}_{2}, \mathrm{~B}_{3}$, and $\mathrm{B}_{4}$ ). The distal area shows a change in seismic facies character of the conformable fine-grained strata from HAC to LAC reflections for most of this phase.

Influences and controls: Pre-existing bathymetry is subtly influenced by the sea-floor expression of the MAD antiform with the western sub-basin deeper than the eastern sub-basin up to the progradation of $\mathrm{B}_{4}$ clinothem after which the MAD antiform is expressed mainly in the bottomset sector (Figs. 14-19). Eustasy continued to fall slowly down to $135 \mathrm{~m}$ below present-day sea level (Lambeck et al., 2014) during the first half of this phase $\left(\mathrm{B}_{2}-\mathrm{B}_{3}\right)$ until reaching stillstand during accumulation of clinothems $\mathrm{A}_{4}$ to $\mathrm{A}_{5}$ (Fig. 8). This eustatic phase reflects an interval of further increase in ice volume of the Laurentide and Scandinavian ice sheets (Dyke et al., 2002; Boulton et al., 2001, respectively). Sediment composition changed at the beginning of Phase 2 (surface s2, 24.7; Fig. 8) when $\mathrm{Ca} / \mathrm{Ti}$ and $\mathrm{K} / \mathrm{Ti}$ ratios increased abruptly. We interpret these shifts to reflect a change of the weathering intensity and a major change of sediment provenance probably driven by the maximum advance of Alpine glaciers documented at $25 \mathrm{ky}$ BP by Monegato et al. (2017). In turn, this evidence suggests a very small buffering time (i.e. delay) between catchment and sink areas. Sediment supply rates in Phase 2 changed as well, showing alternating increases and decreases that were one order of magnitude larger in Type B clinothems than in Type A clinothems. In particular, Clinothem $\mathrm{B}_{4}$ attained the maximum SAR of $200 \mathrm{~km}^{3} / \mathrm{ky}$ for the entire PRLW (Tab. 4b). Regionally, during Phase 2 the Alpine and Apennine glaciers were waxing and waning (Fig. 8; Tab. 4b; Giraudi, 2017; Monegato et al., 2017).

The microfaunal assemblages indicate that surface waters were still cold and productive (Fig. 8; Tab. 4b). In contrast to the Phase 1, however, bottom waters during Phase 2 were affected by reduced ventilation (as indicated by the concurrent abundance peaks of the deep-infaunal species; Fig. 8), reflecting the onset of millennial-scale (from $\mathrm{B}_{2}$ upward) up to centennial-scale 
(from $\mathrm{B}_{4}$ upward) fluctuations of riverine input, witnessing a marked environment variability. This interpretation is based on a decreasing concentration of planktic foraminifera coupled with the minima in abundance of $C$. carinata and concurrent peaks of $N$. depressulus and $N$. pauciloculum, indicative of inner shelf to estuaries/lagoons environments (Fig. 8; Hohenneger et al., 1989, Murray, 2006). Moreover, foraminifera N. depressulus and N. pauciloculum are more common (at intervals even abundant) and continuously distributed compared to the Phase 1, indicating that riverine discharge was closer to the borehole site.

\subsubsection{Phase 3: 55 to $s 6$ (clinothems $B_{5}$ to $A_{6}$ ), 19.0 to $18.0 \mathrm{ky} \mathrm{BP}$}

Patterns: The strata between surfaces s5 and s6 comprise one Type B and one Type A clinothems stacked in an overall progradational to aggradational pattern. The shelf-edge trajectory evolves from slightly descending to ascending. In plan view, sediment accumulation occurs mainly in elliptical, coalescing depocenters that extended to the upper slope and were restricted to the western sub-basin (Figs. 20-21; Tab. 4a). The topset region is interpreted as a local coastal plain with amalgamated channel belts of the Po River (more preserved to the NW) coupled with delta plains of the Apennine rivers (more preserved to the WSW) converging to the MAD. The foreset region appears to have evolved from sandy to muddy prodelta and the proximal bottomset region shifts from Distributary Channel-Lobe Complexes (DLCs in $\mathrm{B}_{5}$ ) to Mass-Transport Complexes (MTCs in $\mathrm{A}_{6}$ ). The distal bottomset area accumulated LAC reflections interpreted as conformable fine-grained strata.

Influences and controls: Pre-existing bathymetry is subtly influenced by the sea-floor expression of the MAD antiform in the bottomset area with the western sub-basin being still deeper than the eastern one. Eustasy began to rise with a jump of $15 \mathrm{~m}$ at the onset of Clinothem $\mathrm{B}_{5}(19 \mathrm{ky}$ BP). The beginning of eustatic rise corresponds globally to the first melt-water pulse (MWP-1), ascribed to the partial collapse of the Northern Hemisphere ice sheets (Yokoyama et al., 2001; 
Tarasov and Peltier, 2004; Bard et al., 1996; Carlson and Clark, 2012), followed by a phase of eustatic rise with rates of ca. $12 \mathrm{~m} / \mathrm{ky}$ (Lea et al., 2002; Mitrovica et al., 2003; Siddal et al., 2003; Peltier and Fairbanks, 2006; Bard et al., 2010; Lambeck et al., 2014; Benjamin et al., 2017). Sediment-supply rates to the basin remained substantially constant with sediment-accumulation rates of 57.5 and $56 \mathrm{~km}^{3} / \mathrm{ky}$ in $\mathrm{B}_{5}$ and $\mathrm{A}_{6}$, respectively (Tab. 4b). Regionally, glaciers were retreating in the Alps and the extent of Apennine glaciers was approaching zero (Fig. 8; Tab. 4b; Giraudi, 2017).

The microfaunal assemblage indicates that surface waters continued to be cold and productive (Fig. 8; Tab. 4). Bottom waters were still affected by minor ventilation (as indicated by the concurrent abundance peaks of the deep-infaunal species; Fig. 8). Fresh-water supply condition were similar to the preceding Phase 2, whereas the abrupt drop in abundance of $C$. carinata suggests variations in water environmental parameters such as salinity and water turbidity.

\subsubsection{Phase 4: s6 to MRS (clinothems $C_{1}$ to $C_{2}$ ), 18.0 to $14.4 \mathrm{ky} \mathrm{BP}$}

Patterns: The strata between surfaces s6 and MRS comprise two Type C clinothems stacked in an overall aggradational pattern. The shelf-edge trajectory is markedly ascending. In plan view, sediment accumulation evolves from an E-W elongated depocenter to a more elliptical depocenter on the slope, coupled with aggradation of the topsets of both clinothems on a broad area of the northwestern shelf (Figs. 22-23; Tab. 4a). During the progradation of Type C clinothems their topsets aggraded up to $45 \mathrm{~m}$ - the thickest and most extensive aggradation of the entire PRLW. The topset is interpreted has a coastal and delta plain where the Po and Apennine channels tended to become isolated, narrower, and thinner with subdued levees compared to the underlying clinothems (Fig. 25). The foreset region comprises heterolithic prodelta deposits characterized by crenulation features possibly reflecting density flows (Fig. 24, and Mulder and Syvitzky, 1995). The proximal bottomset region evolved to strata that are conformable with the underlying clinothems (where 
DLCs in B clinothems and MTCs in A clinothems are preserved). The distal bottomset area is characterized by LAC reflections interpreted as conformable fine-grained strata, similar to preceding Phase-3 strata.

Influences and controls: During this phase, the pre-existing bathymetry evolved to a surface where the MAD antiform is almost buried. Eustasy continued to rise with rates of up to 12 m/ky (e.g. Lambeck et al., 2014) followed by an event of accelerated eustatic rise to a rate of several m per century (Clark et al., 2004), at ca. $14.5 \mathrm{ky} \mathrm{BP.} \mathrm{This} \mathrm{accelerated} \mathrm{rise} \mathrm{has} \mathrm{been}$ attributed to meltwater pulse (MWP-1A; Fairbanks, 1989; Lambeck et al., 2014) after the onset of the Bølling-Allerød warm period and coincided with the formation of the MRS atop Clinothem $\mathrm{C}_{2}$ (Fig. 8; Tab. 4b). Sediment-supply rates to the basin decreased towards the top of this interval by a factor of 5 relative to the preceding Phase-3 SAR; sediment-accumulation rates vary from 30.5 to a minimum of $21.5 \mathrm{~km}^{3} / \mathrm{ky}$ upward in the two $\mathrm{C}_{2}$ clinothems (Tab. $4 \mathrm{~b}$ ), and to about zero at the MRS. Regionally, glaciers were drastically retreating: Alpine glaciers to within their catchment outlets (Monegato et al., 2017) and Apennine glacial extent was close to zero (Giraudi, 2017; Fig. 8; Tab. $4 b)$.

The microfaunal assemblage indicates that surface waters was still influenced by high riverine influence. Increased fresh-water discharge during Phase 4 was probably also the main factor affecting the planktic foraminifera, which responded with 1) a markedly oligotypic assemblage dominated by the small subarctic surface dweller T. quinqueloba (ca. 90\% on average), and 2) the absolute minima in concentration for the entire PRLW (Fig. 8; Tab. 4b). Bottom waters were affected by low ventilation (as indicated by the concurrent abundance peaks of the deep infaunal species; Fig. 8), reflecting centennial oscillations of riverine input. The centennial-scale oscillations in fresh-water input to the basin increased in magnitude that culminated between 18 and 16 ky BP. This trend is recorded by rapid shifts in the abundance of Nonion spp (Fig. 8), and very large oscillations of the $\delta^{18} \mathrm{O}$ composition of planktic foraminifera (up to 2 per mil towards lighter 
values) that reflect salinity drops during phases of enhanced fresh-water discharge. Increased fresh-

water input in Phase 4 is also indicated, in the shallowest coring sites, by a frequency peak of the benthic species Ammonia perlucida (Fig. 8) a taxon with a modern distribution restricted to very shallow shelf areas in the Adriatic Sea (<20m, Jorissen, 1987, 1988) and neighboring lagoon environments (Donnici et al., 1997). At ca. $14.6 \mathrm{ky} \mathrm{BP}$ an abrupt increase of the abundance and a substantial turnover of the assemblages of planktic and benthic foraminifera in all three coring sites records the drowning and abandonment of the PRLW (MRS at 14.4 ky BP; Fig. 8; Tab. 4a, b).

\subsection{Variations between the distance of shoreline and its time-equivalent shelf-edge}

Earlier publications dealing with delta systems have tried to predict the nature of basinal deposits by analyzing specific indicators such as coastal-onlap or shelf-edge trajectory (e.g. Helland Hansen and Martinsen, 1996; Plink-Björklund et al., 2001; Johannessen and Steel, 2005; Carvajal and Steel, 2006; Porebski and Steel, 2006; Ryan et al., 2009; Patruno et al., 2015; Poyatos-Moré et al., 2016; Gong et al., 2016 for a review). Stratigraphic concepts interpret stratal architecture and sediment distribution as results of the interaction of accommodation and sediment supply. Yet, sediment supply to a basin can vary over time in response to autogenic and allogenic processes (e.g Muto and Steel, 1997; Jerolmack and Paola, 2010; Calves et al., 2013). Additionally, the supply to a basin may be out of phase with eustatic changes promoting geometrical variations at local scale (Madof et al., 2016). The PRLW represents an ideal site for deciphering the relations among topset geometry, shelf-edge trajectory, and basinal deposits, and to extrapolate scaling factors related to the different type of clinothems (Pellegrini et al., 2017). During much of the PRLW progradation, the shoreline was docked close to the shelf-edge and a significant amount of sediment was delivered to the basin floor (Pellegrini et al., 2017). Our work suggests that even when the shoreline was in that area, subtle changes in the distance to the shelf-edge result in distinctive topset geometries associated with specific basinal deposits. We conclude that when the shoreline was within $10 \mathrm{~km}$ 
from the shelf-edge, margin destabilization and MTCs were likely promoted (Fig. 26; Type A clinothem). In physiographic settings where the shoreline was closer to the shelf-edge $(<5 \mathrm{~km})$ topset degradation coupled with high sediment bypass to the basin promote the formation of DLCs (Figs. 26 Type B clinothemes). Finally, when the shoreline was more than $10 \mathrm{~km}$ from the shelfedge, and no direct conduit linked the shelf to the slope, no significant volume of coarse sediment reached the basin floor (Figs. 26). These values are in agreement with the independently constrained values of connection between shoreline and canyon head documented by Sweet and Blum (2016). Our finding suggests that subtle and systematic changes in the distance between shoreline and the shelf-edge result in systematically stacked basinal deposits. In this view, we show the importance of carefully analyzing both the topset geometry and the shelf-edge trajectory. Our work demonstrates the potential of Quaternary successions as high-resolution frameworks from which to extrapolate scaling-factor parameters that enhance the predictability of sand-prone deposits in the basin. Whereas previous studies have focused on 100,000 year-scale cycles of glaciation-deglaciation as the temporal scale that determines the balance between shelf aggradation and sediment export to the deep basin, data from the PRLW show that sediment export to the basin can be episodic, even over centennial to millennial time-scales. In this view, our documentation demonstrates, for the first time, the minimum time interval (centennial) in which DLCs can develop with volumes on the order of $60 \mathrm{~km}^{3}$ bypassing the shelf-edge (Tab. 3).

\subsection{The record of composite cyclicity in the PRLW -Sequence Stratigraphic Interpretation-}

We conclude this discussion section with a consideration of how the strata of the PRLW would be interpreted on the basis of sequence stratigraphy alone, in the absence of such detailed chronological and paleontology data. This exercise can reveal how transportable are the lessons from the PRLW and what is essential to predicting the character and distribution of basinal deposits based on shelfal observations. It reinforces the fundamental focus of classic sequence stratigraphy 
(sensu Vail et al., 1977; Neal et al., 2016) on the recognition of various types of stratal surfaces as

foundational to stratigraphic interpretation, correlation, and mapping.

The PRLW represents a succession constrained by robust physical, bio- and chronostratigraphic data of high resolution. It thus represents an excellent natural laboratory wherein to apply the classic sequence-stratigraphic approach to decipher the complex strata of the PRLW in terms of composite cyclicity of forcing mechanisms. Upon initial inspection, the data allowed three alternative hypotheses for the interpretation of the PRLW stratal patterns in a sequence-stratigraphic context; each hypothesis had its pluses and minuses (Fig. 27). The following paragraphs discuss these alternative hypotheses and how we chose our lead hypothesis based on the preponderance of evidence (Fig. 27).

The first hypothesis interprets each A-B clinothem couplet, as well as each Type C clinothem as a parasequence (Fig. 27A). This view is driven by the most obvious and easily traceable surfaces in the PRLW being below the landward shifts that occur at the base of every A+B couplet (except $A_{1}+B_{1}$ ), $A_{6}$, and the two Type $C$ clinothems. The basinward shift below $A_{1}+B_{1}$ couplet is explained by the location of that couplet just above the basal sequence boundary. For the A+B parasequences, Type A clinothems would record the aggradation to progradation characteristic of parasequences (e.g, Van Wagoner et al., 1990). Type B clinothems would record the continuation of progradation, with the truncation at their tops recording in-facies erosion at base of distributary channels (or, alternatively, ravinement during the transgression at the base of the overlying Type A clinothem). Following Neal and Abreu (2009) and Neal et al. (2016), Clinothem Set 1, formed by A-B couplets, represents the Progradational component of a Progradational-Aggradational Set (PA Set) and Clinothem Set 2, with stacked type C clinothems, the Aggradational element of the same PA Set (Pellegrini et al., 2017). On the plus side, this interpretation has the charm of simplicity, it is consistent with the observations of Pellegrini et al. (2017) that the truncation at top of Type B clinothems does not exceed the ca. 10-m distributary-channel depth seen in this system (Amorosi et 
al., 2016), and it explains the lack of well-developed parasequence sets inside the Type A or Type B clinothems that would be expected if these clinothems represent higher-frequency depositional sequences. On the minus side, this interpretation would reveal an internal complexity of parasequences not widely reported — although Gerber et al. (2008) and Plint et al. (2009) suggest some internal complexity, there are no reports of full bypass of the foreset and development of basinally restricted strata of two types (DLCs and MTCs) at the parasequence scale.

The second hypothesis interprets each A-B couplet to represent a complete high-frequency depositional sequence sensu Mitchum and Van Wagoner (1991), but with sequence boundaries defined in the sense of Van Wagoner (1995): each sequence boundary is represented by the erosional surface at the base of a Type A clinothem in the topset zone connected to the erosional surface at the top of a Type B clinothem, to the conformable surface between the Type A and Type B clinothems in the slope zone, to the base of the Type A clinothem beneath the MTC deposits in the basinal zone (Fig. 27; 'Correlation Method 2' of Martin et al., 2009). In this view, all Type A clinothems (except $\mathrm{A}_{1}$ ) would record aggradational $(\mathrm{A})$ stacking, and all Type B clinothems would record progradational $(\mathrm{P})$ stacking (Fig. 27). All the A-B couplets together $\left(\mathrm{A}_{1}\right.$ to $\left.\mathrm{A}_{6}\right)$ form a lowstand/PA sequence set (Fig. 27). Following the same approach, the two Type $\mathrm{C}$ clinothems delimited by regional flooding surfaces form a high-frequency transgressive sequence set (Mitchum and Van Wagoner, 1991). On the plus side, this interpretation explains the two types of basinally restricted strata as related to progradation at or near the shelf-edge, and the high-frequency depositional-sequence boundaries (at base of $\mathrm{A}_{2}$ through $\mathrm{A}_{6}$ ) correlate to mass-transport deposits in the basin as normally observed (e.g., Haq, 1993; Maslin et al., 1998; Beauboeuf and Friedmann, 2000; Posamentier and Kolla, 2003). On the minus side, this interpretation has the sequence boundary at the base of Type A clinothems, where there are landward shifts of facies and not the basinward shifts in facies expected (Fig. 27). This hypothesis leads to the interpretation that the High Amplitude and Chaotic (HACh) seismic facies observed in the most proximal part of Type B 
clinothems are shelf-edge gullies, relatively far from shore, but this is inconsistent with the observation of DLCs on the basal surface of Type B clinothems which imply that the shoreline was less than $5 \mathrm{~km}$ from shelf edge (as discussed in a previous section). In addition, this alternative has two different interpretations of the stacking patterns for Type A (AP for $A_{1}, P A$ for $A_{2}$ to $A_{6}$ ). It also has an APD succession sitting directly upon the basal, lower-order sequence boundary, which is the most likely place to find, instead, a PA succession (Neal and Abreu, 2009). This hypothesis implies that all transgressive systems tracts (R stacking) and practically all the AP stacked parts of the APD systems tract are not developed at a scale resolvable by seismic data, perhaps due to the very rapid progradation of the shelf edge.

The third hypothesis bundles the clinothems into high-frequency sequences differently, and mostly associates each Type $B$ with its overlying Type $A$ clinothem $\left(B_{1}-A_{2}, B_{2}-A_{3}, B_{3}-A_{4}, B_{4}-A_{5}\right.$, $\mathrm{B}_{5}-\mathrm{A}_{6}$; Fig. 27). Following strictly the usage of Mitchum et al. (1977), each sequence boundary is represented by the erosional surface at the base of a Type A clinothem in the topset zone connected to the base of the immediately underlying Type B clinothem at the point where the Type B clinothem laps onto the underlying stratal unit, to the surface at the base of that Type B clinothem in the slope and basinal zones onto which the DLC deposits lap on in the lower-slope zone and lap down in the basinal zone ('Correlation Method 1' of Martin et al., 2009). Each B-A couplet would represent PA stacking $\left(\mathrm{A}_{1}\right.$ is missing its $\mathrm{P}$ component because it directly overlies the lower-order depositional sequence boundary), wherein the upper surface of each Type B clinothem records the change from progradation to aggradation. The topset aggradation observed in Type A clinothems reflects periods of decreased sediment supply to the slope (Tab. 3), as observed in model simulations from Burgess and Prince (2015). The two Type C clinothems would represent parasequences bounded by flooding surfaces developed during the first phase of eustatic rise when sediment supply still keeps pace with the increase in accommodation (as discussed in the previous section). Overall, the interval from $\mathrm{A}_{1}$ to $\mathrm{A}_{6}$ (Clinothem Set 1) would be a progradational sequence 
set, and the interval from $\mathrm{C}_{1}$ to $\mathrm{C}_{2}$ would be an aggradational parasequence set. This interpretation was informed by the close geometric similarity of the PRLW strata to those seen in the XES02 experiment of Martin et al. (2009), which is illustrated in figure 27 and the strict application of the sequence-boundary criteria of Mitchum et al. (1977). On the plus side, this hypothesis explains the basinally restricted stratal units. The sequence boundaries are marked by coastal onlap of Type B clinothems below the pre-existing shelf-break (as expected). This hypothesis implies that the High Amplitude and Chaotic (HACh) seismic facies at the most proximal part of Type B clinothems are amalgamated distributary channels, albeit potentially their subaqueous extensions (sensu Olariu and Bhattacharya, 2006). These strata would still be near shore, because the development of DLCs on the basal surfaces of Type B clinothems means that the shoreline was less than $5 \mathrm{~km}$ from the shelfedge (as discussed in a previous section). Thus, the onlap of Type B clinothems is effectively coastal onlap. The erosion across the tops of Type B clinothems would represent continuing extension of the fluvial system (the 'Ef' surface of Martin et al., 2009) within the PA/Lowstand Systems Tract, and the strata within Type B clinothems is the basinal record of the diachroneity of that erosional surface (Martin et al., 2009). The surface identified in hypothesis 2 (correlation method 2 of Martin et al., 2009), although not a sequence boundary (sensu Mitchum et al., 1977), is still useful because it marks the change from progradation to aggradation within the high-frequency lowstand/PA systems tracts (we propose naming it the "P-A surface"). In addition, the landward shifts at the base of Type A clinothems are consistent with their aggradational stacking (Fig. 27). On the minus side, this hypothesis implies that all high-frequency transgressive and highstand systems tracts (R and APD sets) were not developed at a seismically resolvable scale. This is potentially not a fatal flaw, as discussed above, because those are the stacking patterns and systems tracts that are least likely to be well developed under falling to low accommodation (e.g., Jervey, 1988; Van Wagoner et al., 1990; Martin et al., 2009). 
The balance of evidence, plus versus minus, as well as the use of the original criteria for sequence-boundary identification (i.e., Mitchum et al., 1977) and the close match of the PRLW systems to both the stratal geometries and base-level curve of the XES02 experiment, suggest the third option as our lead hypothesis. Ultimate confirmation probably requires a grid of long cores and wells through the entire PRLW. This would enable detailed facies definition and correlation supported by refined chronological control.

\section{CONCLUSIONS}

The stratal geometry within the Po River Lowstand Wedge, formed in 17 ky encompassing the Last Glacial Maximum, documents repeated short-term changes in accommodation and sediment supply controlling the formation of "elementary" margin-scale clinothems. This revealed how the evolution of a margin-scale system intricately convolves the influences of both global (eustacy) and regional (climate-driven supply fluctuations) controls. In particular:

1. based on the available chronological control, the architectural motif of the elementary clinothems and clinothems sets record sub-Milankovitch cyclicity driven by changes in hydrological balance (fresh-water discharge) and oceanographic regime in the receiving slope basin;

2. distinctive configurations are associated with different timing and quantity of sediment delivered to the basin: respectively, i) centennial-scale, descending shelf-edge trajectory and Channel-Lobe Complexes: Type B clinothem up to $200 \mathrm{~km} / \mathrm{yr}$; ii) millennial-scale, ascending shelf-edge trajectory and Mass Transport Complexes: Type A clinothem up to $100 \mathrm{~km}^{3} / \mathrm{yr}$; iii) millennial-scale markedly ascending shelf-edge trajectory and mud wedges: Type C clinothem up to $30 \mathrm{~km} 3 / \mathrm{yr}$; 
3. distinctive topset geometries (Type B degradational, Type A moderately aggradational and Type C markedly aggradational), associated with distinctive basinal deposits (respectively Channel-Lobe Complexes, Mass Transport Complexes or mud wedges), reflect subtle changes in the relative distance between the shoreline and the time-correlative shelfedge that ranges from virtually zero (Type B) to 10 s of km (Type C);

4. the activation and time span of channel-lobe complexes, such as within the Type B clinothems can occur at century scale;

5. the progradation of Clinothem Set 1 during eustatic fall and stillstand led to an essentially flat shelf-edge trajectory accompanied by significant sediment bypass to the basin and lowoxygen conditions at the seafloor, whereas Clinothem Set 2 records the first phases of sea level rise through ascending shelf-edge trajectory and sediment increasingly sequestered in the topset during increasing accommodation on a broadening shelf sector, along with intermittent increases in benthic-oxygen levels;

6. the main linkage between shelf and basin occurs throughout the falling limb of sea level (Clinothem Set 1), but the major sediment export to the basin coincides with lowstand sea level through a more extensive fluvial system;

7. a substantial decoupling between eustatic rise and enduring river influence on a midlatitude continental margin impacted by post-glacial melt-water injections.

By recognizing the very short-time interval associated to the deposition of each "elementary" clinothem (few hundreds to a few thousand years) we question if, in ancient records, clinothems with a putative duration of hundreds of thousands of years might, at least in some cases, record instead much shorter intervals with most of the geological time condensed in hiatuses and stratigraphic surfaces. We suggest that the PRLW provides valuable insight into the lower end of the range of time spans recorded by such ancient margin-scale clinothems. All of these 
considerations reinforce the focus of classic sequence stratigraphy on surface recognition for interpretation, correlation, mapping, and prediction of rock properties. Finally, we highlighted the importance of integrating paleoenvironment data with the sequence stratigraphic method in the reconstruction of the history of a continental margin.

\section{ACKNOWLEDGMENTS}

The authors dedicate this study to their colleague Giovanni Bortoluzzi, who passed away in 2015. A special tank is due to Marco Ligi and Nevio Zitellini for geophysical data acquisition and processing; Marco Pastore and Filippo D’Oriano for their support during the cruise LSD2014 and processing of geophysical data. Elisabetta Campiani provided additional support for processing the multibeam bathymetry. A particular thank goes to Cpt. Emanuele Gentile and the crew of the R/V Urania during cruise LSD2014. This project was funded by ExxonMobil Upstream Research Company and by the Flagship Project RITMARE-The Italian Research for the Sea. We acknowledge the European Union Project PROMESS-1 (contract EVR1-2001-41) for borehole PRAD 1-2. This is ISMAR-CNR contribution number XXXX. 


\section{REFERENCES CITED}

Amorosi, A., Colalongo, M. L., Fiorini, F., Fusco, F., Pasini, G., Vaiani, S. C., and Sarti, G., 2004, Palaeogeographic and palaeoclimatic evolution of the Po Plain from 150-ky core records: Global and Planetary Change, v. 40(1), p. 55-78.

Amorosi, A., Maselli, V., and Trincardi, F., 2016, Onshore to offshore anatomy of a late Quaternary source-to-sink system (Po Plain-Adriatic Sea, Italy). Earth-Science Reviews, 153, 212-237.

Amorosi, A., Bruno, L., Campo, B., Morelli, A., Rossi, V., Scarponi, D., Hong, W., Bohacs, M. K., and Drexler, T. M., 2017, Global sea-level control on local parasequence architecture from the Holocene record of the Po Plain, Italy. Marine and Petroleum Geology.

Anderson, J. B., A. Rodriguez, K. C. Abdulah, R. H. Fillon, L. A. Banfield, H. A. McKeown, and J. S. Wellner, 2004, Late Quaternary stratigraphic evolution of the northern Gulf of Mexico margin: A synthesis, in J. B. Anderson and R. H. Fillon, eds., Late Quaternary stratigraphic evolution of the northern Gulf of Mexico margin: SEPM Special Publication 79, p. 1-23.

Anderson, J. B., Wallace, D. J., Simms, A. R., Rodriguez, A. B., Weight, R. W., and Taha, Z. P., 2016, Recycling sediments between source and sink during a eustatic cycle: Systems of late Quaternary northwestern Gulf of Mexico Basin. Earth-Science Reviews, 153, 111-138.

Asioli, A., 1996, High resolution foraminifera biostratigraphy in the Central Adriatic basin during the last deglaciation: a contribution to the PALICLAS Project. Memorie-Istituto Italiano di Idrobiologia, v. 55, p. 197-218.

Asioli, A., Trincardi, F., Lowe, J.J., Ariztegui, D., Langone, L., and Oldfield, F., 2001, Submillennial scale climatic oscillations in the central Adriatic during the Late glacial: palaeoceanographic implications: Quaternary Science Reviews, v. 20(11), p. 1201-1221.

Asquith, D. O., 1970, Depositional topography and major marine environments, Late Cretaceous, Wyoming. AAPG Bulletin, 54(7), 1184-1224. 
Bard, E., Hamelin, B., Arnold, M., and Montaggioni, L., 1996, Deglacial sea-level record from Tahiti corals and the timing of global meltwater discharge. Nature, 382(6588), 241.

Bard, E., Hamelin, B., and Delanghe-Sabatier, D., 2010, Deglacial meltwater pulse 1B and Younger Dryas sea levels revisited with boreholes at Tahiti. Science, 327(5970), 1235-1237.

Bazin, L., Landais, A., Lemieux-Dudon, B., Toy’e Mahamadou Kele, H., Veres, D., Parrenin, F., Martinerie, P., Ritz, C., Capron, E., Lipenkov, V., Loutre, M.-F., Raynaud, D., Vinther, B., Svensson, A., Rasmussen, S.O., Severi, M., Blunier, T., Leuenberger, M., Fischer, H., Masson-Delmotte, V., Chappellaz, J., and Wolff, E., 2013, An optimized multi-proxy, multisite Antarctic ice and gas orbital chronology (AICC2012): 120-800 ka, Climate of the Past, v. 9, p. $1715-1731$.

Beaubouef, R. T., and S. J. Friedmann, 2000, High resolution seismic/sequence-stratigraphic framework for the evolution of Pleistocene intraslope basins, western Gulf of Mexico: Depositional models and reservoir analogs, in P. Weimer, R. M. Slatt, J. Coleman, N. C. Rosen, H. Nelson, A. H. Bouma, M. J. Styzen, and D. T. Lawrence, eds., Deep-water reservoirs of the world: Gulf Coast Section SEPM 20th Annual Research Conference, p. 4060.

Benjamin, J., Rovere, A., Fontana, A., Furlani, S., Vacchi, M., Inglis, R. H., Galili, E., Antonioli, F., Sivan, D., Miko, S., Mourtzas, N., Felja, I., Meredith-Williams, M., Goodman-Tchernov, B., Kolaiti, E., Anzidei, M., Gehrels, R., 2017, Late Quaternary sea-level changes and early human societies in the central and eastern Mediterranean Basin: An interdisciplinary review. Quaternary International.

Bhattacharya, J. P., Copeland, P., Lawton, T. F., and Holbrook, J., 2016, Estimation of source area, river paleo-discharge, paleoslope, and sediment budgets of linked deep-time depositional systems and implications for hydrocarbon potential. Earth-Science Reviews, 153, 77-110. 
Boulton, G. S., Dongelmans, P., Punkari, M., and Broadgate, M., 2001, Palaeoglaciology of an ice sheet through a glacial cycle: the European ice sheet through the Weichselian. Quaternary Science Reviews, v. 20(4), p. 591-625.

Bourne, A.J., Lowe, J.J., Trincardi, F., Asioli, A., Blockley, S.P.E., Wulf, S. Matthews, I.P. Piva, A., and Vigliotti, L., 2010, Distal tephra record for the last ca 105,000 years from core PRAD 1-2 in the central Adriatic Sea: implications for marine tephrostratigraphy: Quaternary Science Reviews v. 29, p. 3079-3094.

Boyd, R., Suter, J., and Penland, S., 1989, Relation of sequence stratigraphy to modern sedimentary environments. Geology, 17(10), 926-929.

Bruno, L., Amorosi, A., Severi, P., \& Costagli, B., 2017, Late Quaternary aggradation rates and stratigraphic architecture of the southern Po Plain, Italy: Basin Research, 29(2), 234-248.

Burgess, P. M., and Prince, G. D., 2015, Non-unique stratal geometries: implications for sequence stratigraphic interpretations. Basin Research, 27(3), 351-365.

Campo, B., Amorosi, A., and Vaiani, S. C., 2017, Sequence stratigraphy and late Quaternary paleoenvironmental evolution of the Northern Adriatic coastal plain (Italy). Palaeogeography, Palaeoclimatology, Palaeoecology, 466, 265-278.

Calves, G., Toucanne, S., Jouet, G., Charrier, S., Thereau, E., Etoubleau, J., Marseset, T., Droz, L., Bez, M., Abreu, V., Jorry, S., Mulder, T., and Lericolais, G., 2013, Inferring denudation variations from the sediment record; an example of the last glacial cycle record of the Golo Basin and watershed, East Corsica, western Mediterranean sea. Basin Research, 25(2), 197218.

Carlson, A. E., and Clark, P. U., 2012, Ice sheet sources of sea level rise and freshwater discharge during the last deglaciation. Reviews of Geophysics, 50(4), p. 1-72.

Carvajal, C. R., Steel, R. J., 2006, Thick turbidite successions from supply-dominated shelves during sea-level highstand. Geology, 34(8), 665-668. 
Carvajal, C., Steel, R., and Petter, A., 2009, Sediment supply: the main driver of shelf-margin growth: Earth-Science Reviews, v. 96(4), p. 221-248.

Cattaneo, A., Correggiari, A., Langone, L., Trincardi, F., 2003, The late-Holocene Gargano subaqueous delta, Adriatic shelf: sediment pathways and supply fluctuations. Marine Geology, 193(1), 61-91.

Catuneanu, O., Abreu, V., Bhattacharya, J. P., Blum, M. D., Dalrymple, R. W., Eriksson, P. G., Winker, C., 2009, Towards the standardization of sequence stratigraphy. Earth-Science Reviews, 92(1), 1-33.

Clark, P. U., McCabe, A. M., Mix, A. C., and Weaver, A. J., 2004, Rapid rise of sea level 19,000 years ago and its global implications. Science, 304 (5674), 1141-1144.

Dyke, A. S., Andrews, J. T., Clark, P. U., England, J. H., Miller, G. H., Shaw, J., and Veillette, J. J. 2002, The Laurentide and Innuitian ice sheets during the last glacial maximum. Quaternary Science Reviews, v. 21(1), p. 9-31.

Dalla Valle, G., Gamberi, F., Rocchini, P., Minisini, D., Errera, A., Baglioni, L., Trincardi, F., 2013a, 3D seismic geomorphology of mass transport complexes in a foredeep basin: Examples from the Pleistocene of the Central Adriatic Basin (Mediterranean Sea). Sedimentary Geology, 294, 127-141.

Dalla Valle, G., Gamberi, F., Trincardi, F., Baglioni, L., Errera, A., Rocchini, P., 2013b, Contrasting slope channel styles on a prograding mud-prone margin. Marine and Petroleum Geology, 41, 72-82.

Del Bianco, F., Gasperini, L., Giglio, F., Bortoluzzi, G., Kljajic, Z., Ravaioli, M., 2014, Seafloor morphology of the Montenegro/N. Albania Continental Margin (Adriatic Sea-Central Mediterranean). Geomorphology, 226, 202-216. 
Doglioni, C., Mongelli, F., and Pieri, P., 1994, The Puglia uplift (SE Italy): An anomaly in the foreland of the Apenninic subduction due to buckling of a thick continental lithosphere: Tectonics, v. 13, p. 1309-1321, doi:10.1029/94TC01501.

Donnici, S., Serandrei Barbero, R., Taroni, G., 1997. Living benthic foraminifera in the lagoon of Venice (Italy): population dynamics and its significance. Micropaleontology 43, 440-

Fairbanks, R. G., 1989, A 17, 000-year glacio-eustatic sea level record: influence of glacial melting rates on the Younger Dryas event and deep-ocean circulation. Nature, 342(6250), 637-642.

Fanget, A. S., Berné, S., Jouet, G., Bassetti, M. A., Dennielou, B., Maillet, G. M., and Tondut, M, 2014, Impact of relative sea level and rapid climate changes on the architecture and lithofacies of the Holocene Rhone subaqueous delta (Western Mediterranean Sea): Sedimentary Geology, 305, 35-53.

Fatoke, O. A., and Bhattacharya, J. P., 2010. Controls on Depositional Systems and Sequence Stratigraphy of the Pliocene-Pleistocene Strata of Eastern Niger Delta, Nigeria. Search and Discovery Article, 10220.

Florineth, D., and Schlüchter, C., 1998, Reconstructing the Last Glacial Maximum (LGM) ice surface geometry and flowlines in the Central Swiss Alps. Eclogae Geologicae Helvetiae, 91, 391-407.

Frignani, M., Langone, L., Ravaioli, M., Sorgente, D., Alvisi, F., Albertazzi, S., 2005, Finesediment mass balance in the western Adriatic continental shelf over a century time scale. Marine Geology, 222, 113-133.

Geletti, R., Del Ben, A., Busetti, M., Ramella, R., and Volpi, V., 2008, Gas seeps linked to salt structures in the Central Adriatic Sea: Basin Research, 20(4), 473-487.

Gerber, T., Pratson, L., Wolinsky, M., Steel, R., Mohr, J., Swenson, J. and Paola, C. 2008, Clinoform progradation by turbidity currents: modeling and experiments. Journal of Sedimentary Research, 78, $220-238454$. 
Ghielmi, M., Minervini, M., Nini, C., Rogledi, S., and Rossi, M., 2013, Late Miocene-Middle Pleistocene sequences in the Po Plain-Northern Adriatic Sea (Italy): the stratigraphic record of modification phases affecting a complex foreland basin: Marine and Petroleum Geology, $42,50-81$.

Giraudi, C., 2017, Climate evolution and forcing during the last $40 \mathrm{ka}$ from the oscillations in Apennine glaciers and high mountain lakes, Italy. Journal of Quaternary Science.

Goineau, A., Fontanier, C., Jorissen, F.J., Lansard, B., Buscail, R., Mouret, A., Kerhervé, P., Zaragosi, S., Ernoult, E., Artéro, C., Anschutz, P., Metzger, E., Rabouill, C. 2011. Live (stained) benthic foraminifera from the Rhône prodelta (Gulf of Lion, NW Mediterranean): environmental controls on a river-dominated shelf. Journal Sea Research, 65, 58-75.

Gong, C., Steel, R. J., Wang, Y., Lin, C., and Olariu, C., 2016, Shelf-margin architecture variability and its role in sediment-budget partitioning into deep-water areas. Earth-Science Reviews, $154,72-101$.

Hayward, W., S. Kawagata, A. Sabaa, H. Grenfell, L. Van Kerckhoven, K. Johnson, and E. Thomas. 2012. The Last Global Extinction (Mid-Pleistocene) of Deep-sea Benthic Foraminifera (Chrysalogoniidae, Ellipsoidinidae, Glandulonodosariidae, Plectofrondiculariidae, Pleurostomellidae, Stilostomellidae), Their Late Cretaceous-Cenozoic History and Taxonomy. Cushman Foundation for Foraminiferal Research Special Publication, 43, p. 408.

Haq, B.U., 1993, Deep sea response to eustatic changes and significance of gas hydrates for continental margin stratigraphy, in Posamentier, H.W., Summerhayes, C.P., Haq, B.U., and Allen, G.P., eds., Sequence Stratigraphy and Facies Associations: International Association of Sedimentologists, Special Publication 18, p. 93-106.

Helland-Hansen, W., and Martinsen, O. J., 1996, Shoreline trajectories and sequences: description of variable depositional-dip scenarios: Journal of Sedimentary Research, v. 66(4), p. 670-688. 
Helland-Hansen, W., and Hampson, G.J., 2009, Trajectory analysis: concepts and applications: Basin Research, v. 21(5), p. 454-483.

Hemleben, C., Spindler, M., Anderson, O.R., 1989, Modern Planktonic foraminifera. SpringerVerlag, New York. p. 1-363.

Henriksen, S., Hampson, G.J., Helland-Hansen, W., Johannessen, E.P., and Steel, R.J., 2009, Shelf edge and shoreline trajectories, a dynamic approach to stratigraphic analysis: Basin Research, v. 21(5), p. 445-453.

Hess, S., and F. J. Jorissen, 2009, Distribution patterns of living benthic foraminifera from Cap Breton canyon, Bay of Biscay: Faunal response to sediment instability, Deep Sea Res., Part I, 56, 1555-1578, doi:10.1016/j.dsr.2009.04.003.

Hohenegger, J., Piller, W. and Ch. Baal, 1989: Reasons for the spatial microdistributions of foraminifers in an intertidal pool (Northern Adriatic Sea). P.S.Z.N. I. Marine Ecology, 10, 4378, Berlin-Hamburg.

Hovland, M. and Curzi, P., 1989, Gas seepage and assumed mud diapirism in the Italian central Adriatic Sea. Mar. Petrol. Geol., v. 6, p. 161-169.

Hughes, P. D., and Gibbard, P. L., 2015, A stratigraphical basis for the Last Glacial Maximum (LGM). Quaternary International, 383, 174-185.

IEA, 2013, Resources to reserves 2013; oil, gas, and coal technologies for energy markets of the future, OECD-IEA, Paris, France, 272 pp. (ISBN 978-92-64-08354-7).

Jerolmack, D. J., and Paola, C., 2010, Shredding of environmental signals by sediment transport. Geophysical Research Letters, 37(19).

Jervey, M. T., 1988, Quantitative geological modeling of siliciclastic rock sequences and their seismic expression.

Johannessen, E.P., and Steel, R.J., 2005, Shelf-margin clinoforms and prediction of deepwater sands. Basin Research, v. 17(4), p. 521-550. 
Jorissen F.J. 1987. The distribution of benthic foraminifera in the Adriatic Sea. Marine Micropaleontology, 12, 21-48.

Jorissen F.J. 1988. Benthic Foraminifera from the Adriatic Sea; principles of phenotypic variation. Utrecht Micropaleontology Bulletin, 37, 176.

Jorissen, F.J., Asioli, A., Borsetti, A., Capotondi, L., De Visser, J., Hilgen, F., Rohling, E., Van der Borg, K., Grazzini, C.V., Zachariasse, W., 1993. Late quaternary central Mediterranean biochronology. Marine Micropaleontology, 21, 169-189.

Jorissen, F.J., 1999. Benthic foraminiferal successions across Late Quaternary Mediterranean sapropels. Marine Geology 153, 91-101.

Jouet, G., Berne, S., Rabineau, M., Bassetti, M. A., Bernier, P., Dennielou, B., Taviani, M., 2006, Shoreface migrations at the shelf edge and sea-level changes around the Last Glacial Maximum (Gulf of Lions, NW Mediterranean). Marine Geology, 234(1), 21-42.

Kettner, A. J., Syvitski, J. P., 2008, HydroTrend v. 3.0: A climate-driven hydrological transport model that simulates discharge and sediment load leaving a river system. Computers \& Geosciences, 34(10), 1170-1183.

Kolla, V., Perlmutter, M. A.,1993, Timing of turbidite sedimentation on the Mississippi Fan AAPG Bull., v. 77, p. 1129-1141.

Knudsen, K.L. (Ed), 1971, Late Quaternary Foraminifera from the Vendsyssel, Denmark and Sandnes, Norway - systematic part. In: Feyling-Hanssen, Jørgensen, Knudsen and Lykke Andersen (Eds): Late Quaternary Foraminifera from the Vendsyssel, Denmark and Sandnes, Norway. Bulletin of the Geological Society of Denmark, 21, 185-295.

Lambeck, K., Rouby, H., Purcell, A., Sun, Y., and Sambridge, M., 2014, Sea level and global ice volumes from the Last Glacial Maximum to the Holocene. Proceedings of the National Academy of Sciences, 111(43), 15296-15303. 
Lea, D. W., Martin, P. A., Pak, D. K., and Spero, H. J., 2002, Reconstructing a 350ky history of sea level using planktonic $\mathrm{Mg} / \mathrm{Ca}$ and oxygen isotope records from a Cocos Ridge core. Quaternary Science Reviews, 21(1), 283-293.

Madof, A. S., Harris, A. D., and Connell, S. D., 2016, Nearshore along-strike variability: Is the concept of the systems tract unhinged?: Geology, 44(4), 315-318.

Martin, J., Paola, C., Abreu, V., Neal, J., and Sheets, B., 2009, Sequence stratigraphy of experimental strata under known conditions of differential subsidence and variable base level AAPG bulletin, 93(4), 503-533.

Maselli, V., Trincardi, F., Cattaneo, A., Ridente, D., and Asioli, A., 2010, Subsidence patterns in the central Adriatic and its influence on sediment architecture during the last 400 kyr: Journal of Geophysical Research: Solid Earth, v. 115, n. B12, doi: 10.1029/2010JB007687.

Maslin, M., Mikkelsen, N., Vilela, C., and Haq, B.U., 1998, Sea-level and gas-hydrate-controlled catastrophic sediment failures of the Amazon fan: Geology, v. 26, p. 1107-1110.

Milliman, J. D., and Farnsworth, K. L., 2013, River discharge to the coastal ocean: a global synthesis. Global and planetary change, v. 39, p. 53-64.

Milliman, J. D., Bonaldo, D., and Carniel, S., 2016, Flux and fate of river-discharged sediments to the Adriatic Sea. Advances in Oceanography and Limnology, 7(2).

Mitchum Jr, R. M., Vail, P. R., and Sangree, J. B., 1977, Seismic stratigraphy and global changes of sea level: Part 6. Stratigraphic interpretation of seismic reflection patterns in depositional sequences: Section 2. Application of seismic reflection configuration to stratigraphic interpretation.

Mitchum, R.M.J., Van Wagoner, J.C., 1991. High-frequency sequences and their stacking patterns: sequence-stratigraphic evidence of high-frequency eustatic cyclces. Sedimentary Geology 70(2-4), 131-160. doi: 10.1016/0037-0738(91)90139-5. 
Mitrovica, J. X., 2003, Recent controversies in predicting post-glacial sea-level change. Quaternary Science Reviews, 22(2), 127-133.

Mojtahid, M., Jorissen, F., Lansard, B., Fontanier, C., Bombled, B., Rabouille, C., 2009. Spatial distribution of live benthic foraminifera in the Rhône prodelta: faunal response to a continental-marine organic matter gradient. Marine Micropaleontology, 70 (3-4), 177-200.

Monegato, G., Ravazzi, C., Donegana, M., Pini, R., Calderoni, G., and Wick, L., 2007, Evidence of a two-fold glacial advance during the last glacial maximum in the Tagliamento end moraine system (eastern Alps): Quaternary Research, v. 68, p. 284-302, doi:10.1016/j.yqres.2007.07.002.

Monegato, G., Scardia, G., Hajdas, I., Rizzini, F. and Piccin, A., 2017, The Alpine LGM in the boreal icesheets game, Scientific Reports, vol. 7: 2078, doi:10.1038/s41598-017-02148-7.

Mulder, T., Syvitski, J.P.M., 1995, Turbidity currents generated at river mouths during exceptional discharges to the world oceans: Journal of Geology 103, 285-299.

Muller-Karger, F.E., Varela, R., Thunell, R., Luerssen, R., Chuanamin Hu, Walsh, J.J., 2005, The importance of continental margins in the global carbon cycle: Geophysical Research Letters v. 32, L01602.

Murray, J.W. 2006. Ecology and Applications of Benthic Foraminifera. Cambridge University Press, 426 p.

Murray, J.W. 2013. Living benthic foraminifera: biogeographical distributions and the significance of rare morphospecies. Journal of Micropalaeontology, 32, 1-58.

Muto, T., and Steel, R. J., 1997, Principles of regression and transgression: the nature of the interplay between accommodation and sediment supply: perspectives. Journal of Sedimentary Research, 67(6).

Neal, J., Abreu, V., 2009. Sequence stratigraphy hierarchy and the accommodation succession method. Geology, v. 37(9), p. 779-782. 
Neal, J. E., Abreu, V., Bohacs, K. M., Feldman, H. R., and Pederson, K. H., 2016, Accommodation succession $(\delta \mathrm{A} / \delta \mathrm{S})$ sequence stratigraphy: observational method, utility and insights into sequence boundary formation. Journal of the Geological Society, 173(5), 803-816.

Olariu, C., and Bhattacharya, J. P., 2006, Terminal distributary channels and delta front architecture of river-dominated delta systems. Journal of sedimentary research, 76(2), 212-233.

Patruno, S., Hampson, G. J., Jackson, C. A. L., Whipp, P. S., 2015. Quantitative progradation dynamics and stratigraphic architecture of ancient shallow-marine clinoform sets: a new method and its application to the Upper Jurassic Sognefjord Formation, Troll Field, offshore Norway: Basin Research.

Pellegrini, C., Maselli, V., Cattaneo, A., Piva, A., Ceregato, A., and Trincardi, F., 2015, Anatomy of a compound delta from the post-glacial transgressive record in the Adriatic Sea. Marine Geology, 362, 43-59.

Pellegrini, C., Maselli, V., Gamberi, F., Asioli, A., Bohacs, K. M., Drexler, T. M., and Trincardi, F. 2017, How to make a 350-m-thick lowstand systems tract in 17,000 years: The Late Pleistocene Po River (Italy) lowstand wedge. Geology, G38848-1.

Pellegrini, C., Bohacs, K. M., Drexler, T. M., Gamberi, F., Rovere, M., and Trincardi, F, in press, Identifying the Sequence Boundary in Over- and Under-Supplied Contexts: the Case of the Late Pleistocene Adriatic Continental Margin.

Peltier, W. R., and Fairbanks, R. G., 2006, Global glacial ice volume and Last Glacial Maximum duration from an extended Barbados sea level record: Quaternary Science Reviews, v. 25(23), p. $3322-3337$.

Pillans, B., Chappell, J., and Naish, T. R., 1998, A review of the Milankovitch climatic beat: template for Plio-Pleistocene sea-level changes and sequence stratigraphy. Sedimentary Geology, 122(1), 5-21. 
Pirmez, C., Pratson, L. F., Steckler, M. S., 1998. Clinoform development by advection-diffusion of suspended sediment: Modeling and comparison to natural systems. Journal of Geophysical Research: Solid Earth (1978-2012), 103(B10), 24141-24157.

Piva, A., Asioli, A., Schneider, R. R., Trincardi, F., Andersen, N., Colmenero-Hidalgo, E., Dennielou, B., Flores, J.A., and Vigliotti L., 2008a, Climatic cycles as expressed in sediments of the PROMESS1 borehole PRAD1-2, Central Adriatic, for the last $370 \mathrm{ka}, 1$ : integrated stratigraphy. Geochemistry, Geophysics, Geosystems, v. 9 (1), Q01R01, doi: 10.1029/2007GC001713.

Piva, A., Asioli, A., Andersen, N., Grimalt, J. O., Schneider, R. R., and Trincardi, F, 2008b, Climatic cycles as expressed in sediments of the PROMESS1 borehole PRAD1-2, central Adriatic, for the last 370 ka: 2. Paleoenvironmental evolution. Geochemistry, Geophysics, Geosystems, 9(3).

Plink-Björklund, P., Mellere, D., Steel, R. J., 2001, Turbidite variability and architecture of sandprone, deep-water slopes: Eocene clinoforms in the Central Basin, Spitsbergen. Journal of Sedimentary Research, 71(6), 895-912.

Plint, A.G., and Kreitner, M.A., 2007, Extensive thin sequences spanning Cretaceous foredeep suggest high-frequency eustatic control: Late Cenomanian, Western Canada foreland basin: Geology, v. 35(8), p. 735-738.

Plint, A. G., 2009, High-frequency Relative Sea-level Oscillations in Upper Cretaceous Shelf Clastics of the Alberta Foreland Basin: Possible Evidence for a Glacio-Eustatic Control? Sedimentation, Tectonics and Eustasy. Sedimentation, Tectonics and Eustasy, Spec. Publ. Int. Assoc. Sedimentol, 12, 409-428.

Porębski, S. J., and Steel, R. J., 2003, Shelf-margin deltas: their stratigraphic significance and relation to deepwater sands. Earth-Science Reviews, 62(3), 283-326. 
Posamentier, H. W., and Kolla, V., 2003, Seismic geomorphology and stratigraphy of depositional elements in deep-water settings. Journal of sedimentary research, 73(3), 367-388.

Poyatos-Moré, M., Jones, G. D., Brunt, R. L., Hodgson, D. M., Wild, R. J., and Flint, S. S., 2016, Mud-Dominated Basin-Margin Progradation: Processes and Implications. Journal of Sedimentary Research, 86(8), 863-878.

Pujol, C., Vergnaud Grazzini, C., 1995, Distribution patterns of live planktic foraminifera as related to regional hydrography and productive systems of the Mediterranean Sea. Marine Micropaleontology v. 25, p. 187-217.

Ridente, D., and Trincardi, F., 2005, Pleistocene "muddy" forced-regression deposits on the Adriatic shelf: a comparison with prodelta deposits of the late Holocene highstand mud wedge. Marine Geology, 222, 213-233.

Ridente, D., Trincardi, F., Piva, A., and Asioli, A. 2009, The combined effect of sea level and supply during Milankovitch cyclicity: Evidence from shallow-marine $\delta 180$ records and sequence architecture (Adriatic margin): Geology, v. 37, p. 1003-1006.

Roberts, H. H., Fillon, R. H., Kohl, B., Robalin, J. M., and Sydow, J. C., 2004, Depositional architecture of the Lagniappe Delta: sediment characteristics, timing of depositional events, and temporal relationship with adjacent shelf-edge deltas.

Rossi, M., Minervini, M., Ghielmi, M., and Rogledi, S., 2015, Messinian and Pliocene erosional surfaces in the Po Plain-Adriatic Basin: Insights from allostratigraphy and sequence stratigraphy in assessing play concepts related to accommodation and gateway turnarounds in tectonically active margins: Marine and Petroleum Geology, 66, 192-216.

Royden, L., Patacca, E., and Scandone, P., 1987, Segmentation and configuration of subducted lithosphere in Italy: an important control on thrust-belt and foredeep-basin evolution. Geology, v. 15(8), p. 714-717. 
Ryan, M. C., Helland-Hansen, W., Johannessen, E. P., and Steel, R. J., 2009, Erosional vs. accretionary shelf margins: the influence of margin type on deepwater sedimentation: an example from the Porcupine Basin, offshore western Ireland. Basin Research, 21(5), 676-703.

Schmiedl, G., de Bovèe, F., Buscail, R., Charrière, B., Hemleben, C., Medernach, L., and Picon, P. 2000. Trophic control of benthic foraminiferal abundance and microhabitat in the bathyal Gulf of Lions, western Mediterranean Sea, Marine Micropaleontology, 40, 167-188.

Sheets, B.A., Hickson, T.A., and Paola, C., 2002, Assembling the stratigraphic record: Depositional patterns and time-scales in an experimental alluvial basin: Basin Research, v. 14, p. 287-301, doi:10.1046/j.1365-2117.2002.00185.x.

Siddall, M., Rohling, E. J., Almogi-Labin, A., Hemleben, C., Meischner, D., Schmelzer, I., and Smeed, D. A., 2003, Sea-level fluctuations during the last glacial cycle. Nature, 423(6942), 853-858.

Simeoni U, Pano N, Ciavola P, 1997, The coastline of Albania: morphology, evolution and coastal management issues. CIESM Publ. 18: 561-168.

Steckler, M.S., Mountain, G.S., Miller, K.G., Christie-Blick, N., 1999, Reconstruction of Tertiary progradation and clinoform development on the New Jersey passive margin by 2-D backstripping. Marine Geology 154, 399-420.

Steel, R. J., Crabaugh, J., Schellpeper, M., Mellere, D., Plink-Björklund, P., Deibert, J., and Loeseth, T. 2000, Deltas vs. rivers on the shelf edge: their relative contributions to the growth of shelf-margins and basin-floor fans (Barremian and Eocene, Spitsbergen): Deepwater Reservoirs of the World, p. 981-1009.

Storms, J.E., Weltje, G.J., Terra, G.J., Cattaneo, A., and Trincardi, F., 2008, Coastal dynamics under conditions of rapid sea-level rise: Late Pleistocene to Early Holocene evolution of barrier-lagoon systems on the northern Adriatic shelf (Italy): Quaternary Science Reviews, v. 27(11), p. 1107-1123. 
Suter, J.R., and Berryhill Jr, H.L., 1985, Late Quaternary shelf-margin deltas, northwest Gulf of Mexico: AAPG Bulletin, v. 69(1), p. 77-91.

Sydow, J., Finneran, J., Bowman, A. P., Rosen, H., Fillon, R., and Anderson, J., 2003, Stacked shelf-edge delta reservoirs of the Columbus Basin, Trinidad, West Indies: Shelf-Margin Deltas and Linked Downslope Petroleum Systems, p. 441-465.

Sweet, M. L., and Blum, M. D., 2016, Connections Between Fluvial To Shallow Marine Environments and Submarine Canyons: Implications For Sediment Transfer To Deep Water. Journal of Sedimentary Research, 86(10), 1147-1162.

Sweetman, A.K., S. Sommer, O. Pfannkuche, U. Witte. 2009, Retarded response by macrofaunasize foraminifera to phytodetritus in a deep Norwegian fjord. Journal of Foraminiferal Research, 39(1), 15-22.

Swenson J. B., Paola C., Pratson L., Voller V. R., Murray A. B., 2005. Fluvial and marine controls on combined subaerial and subaqueous delta progradation: Morphodynamic modeling of compound-clinoform development. Journal of Geophysical Research: Earth Surface, 110, 0148-0227.

Tarasov, L., and Peltier, W. R., 2004, A geophysically constrained large ensemble analysis of the deglacial history of the North American ice-sheet complex. Quaternary Science Reviews, 23(3), 359-388.

Tesi, T., Asioli, A., Minisini, D., Maselli, V., Dalla Valle, G., Gamberi, F., Langone, L., Cattaneo, A., Montagna, P., Trincardi, F., 2017, Large-scale response of the Eastern Mediterranean thermohaline circulation to African monsoon intensification during sapropel S1 formation. Quaternary Science Reviews, 159, 139-154.

Trincardi, F., and Field, M. E., 1991, Geometry, lateral variation, and preservation of downlapping regressive shelf deposits: eastern Tyrrhenian Sea margin, Italy: Journal of Sedimentary Research, 61(5). 
Trincardi, F., Correggiari, A., and Roveri, M., 1994, Late Quaternary transgressive erosion and deposition in a modern epicontinental shelf: the Adriatic semienclosed basin. Geo-Marine Letters, 14(1), 41-51.

Trincardi F., Cattaneo, A., Asioli, A., Correggiari, A., and Langone L., 1996, Stratigraphy of the late-Quaternary deposits in the central Adriatic basin and the record of short-term climatic events. In: F. Oldfield and P. Guilizzoni (Editors), Palaeoenvironmental Analysis of Italian Crater Lake and Adriatic Sediments, Memorie dell'Istituto Italiano di Idrobiologia, v. 55, p. $39-70$.

Trincardi, F., and Correggiari, A., 2000, Quaternary forced regression deposits in the Adriatic basin and the record of composite sea-level cycles. Geological Society, London, Special Publications, 172(1), 245-269.

Trincardi, F., Cattaneo, A., Correggiari, A., and Ridente, D., 2004, Evidence of soft sediment deformation, fluid escape, sediment failure and regional weak layers within the late Quaternary mud deposits of the Adriatic Sea. Marine Geology, 213(1), 91-119.

Urgeles, R., Cattaneo, A., Puig, P., Liquete, C., De Mol, B., Amblàs, D., and Trincardi, F., 2011, A review of undulated sediment features on Mediterranean prodeltas: distinguishing sediment transport structures from sediment deformation: Marine Geophysical Research, v. 32(1-2), p. 49-69.

Vail, P. R., Mitchum Jr, R. M., Thompson III, S., 1977. Seismic Stratigraphy and Global Changes of Sea Level: Part 4. Global Cycles of Relative Changes of Sea Level.: Section 2. Application of Seismic Reflection Configuration to Stratigraphic Interpretation.

Vail, P.R., Audemard, F., Bowman, S.A., Eisner, P.N. and Perez-Cruz, G., 1991, The stratigraphic signatures of tectonics, eustasy and sedimentation: an overview: A. Seilacher and G. Eisner (Editors), Cycles and Events in Stratigraphy, Springer-Verlag, Tiibingen, p. 617-659. 
Van der Zwaan, G. J., F. J. Jorissen. 1991. Biofacial patterns in river-induced anoxia. In: R. Tyson and Th. Pearson Eds.), Modern and ancient continental shelf anoxia. Geological Society of London Special Publication, 58, 65-82.

Van Wagoner, J. C., Mitchum, R. M., Campion, K. M., and Rahmanian, V. D., 1990, Siliciclastic sequence stratigraphy in well logs, cores, and outcrops: concepts for high-resolution correlation of time and facies.

Van Wagoner, J. C., 1995, Sequence stratigraphy and marine to nonmarine facies architecture of foreland basin strata, Book Cliffs, Utah, USA.

Voelker, A.H.L. and workshop participants, 2002, Global distribution of centennial-scale records for Marine Isotope Stage (MIS) 3: a database. Quaternary Science Reviews 21, 1185-1212.

Walker, M. J. C., M. Berkelhammer, S. Björck, L. C. Cwynar, D. A. Fisher, A. J. Long, J. J. Lowe, R. M. Newnham, S. O. Rasmussen and H. Weiss, 2009, Formal subdivision of the Holocene Series/Epoch: a Discussion Paper by a Working Group of INTIMATE (Integration of icecore, marine and terrestrial records) and the Subcommission on Quaternary Stratigraphy (International Commission on Stratigraphy). Journal of Quaternary Science, 27, 7: 649-659.

Walsh, J.J., 1991, Importance of continental margins in the marine biogeochemical cycling of carbon and nitrogen, Nature v. 350, p. 53-55 (doi:10.1038/350053a0).

Yokoyama, Y., Lambeck, K., De Deckker, P., Johnston, P., and Fifield, L. K., 2000, Timing of the Last Glacial Maximum from observed sea-level minima. Nature, 406(6797), 713-716.

Zecchin, M., Baradello, L., Brancolini, G., Donda, F., Rizzetto, F., and Tosi, L., 2008, Sequence stratigraphy based on high-resolution seismic profiles in the late Pleistocene and Holocene deposits of the Venice area: Marine Geology, v. 253(3), p. 185-198. 


\section{FIGURE CAPTIONS}

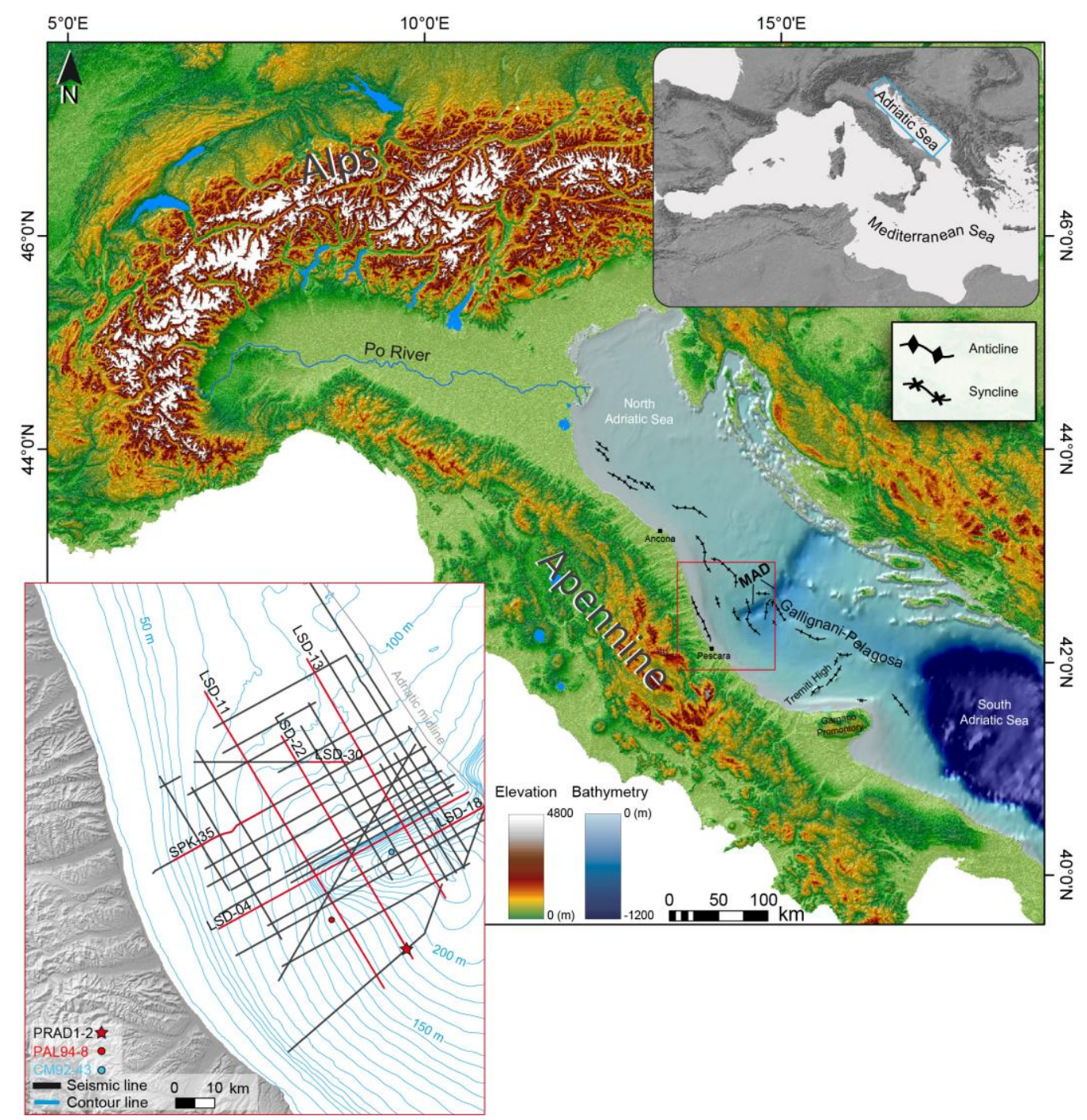

Fig. 1. Digital elevation model for the Adriatic Sea and surrounded area with structural elements.

MAD: Mid Adriatic Depression. Top right: Adriatic Sea location in the Mediterranean Sea. Bottom left: detail of the MAD with the orientation of seismic grid, and position of sediment cores and borehole. Seismic profiles showed in this work are highlighted in red. 


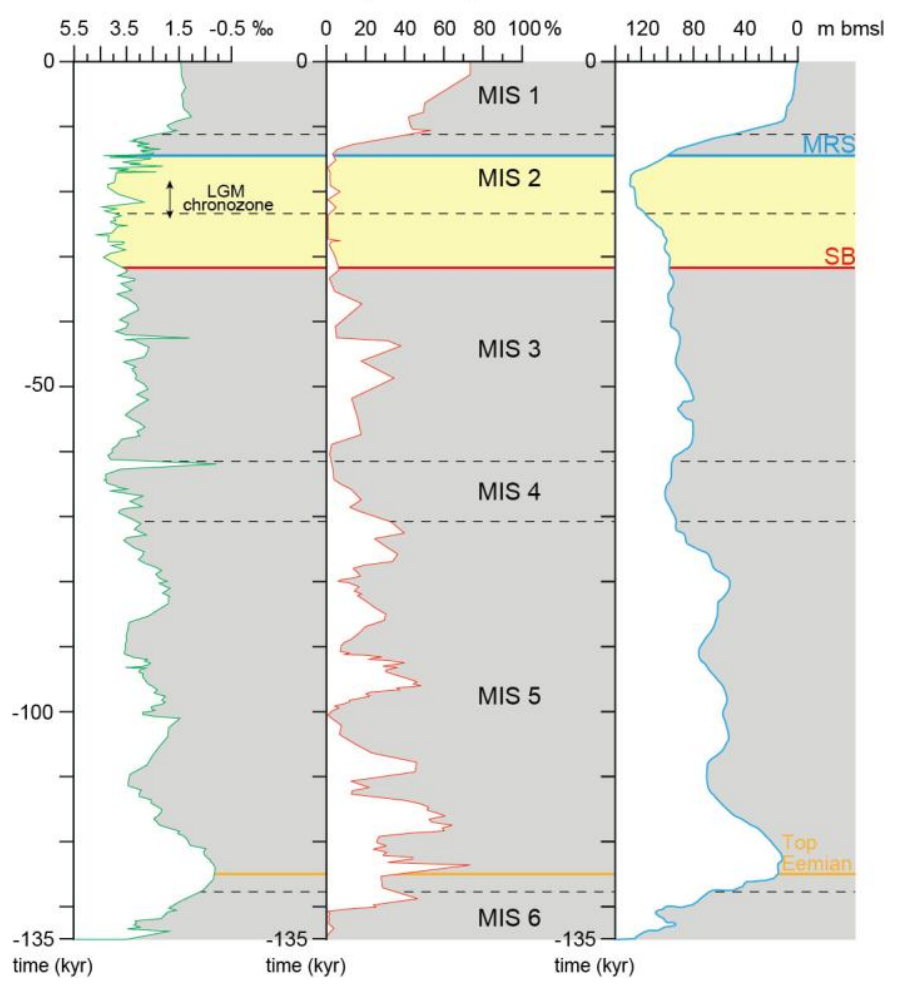

Fig. 2. $\delta^{18} \mathrm{O}$ (G. bulloides), warm planktic species (see Data, Material and Strategy for the species included), and eustatic curves. Vertical scale is in time (ky BP). Horizontal dashed lines mark the boundaries of Marin Isotopic Stages. The PRLW forms between SB and MRS surfaces (yellow interval), during an overall cold climatic interval and encompasses the late phase of sea level fall, the lowstand, and the early phase of sea level rise. 


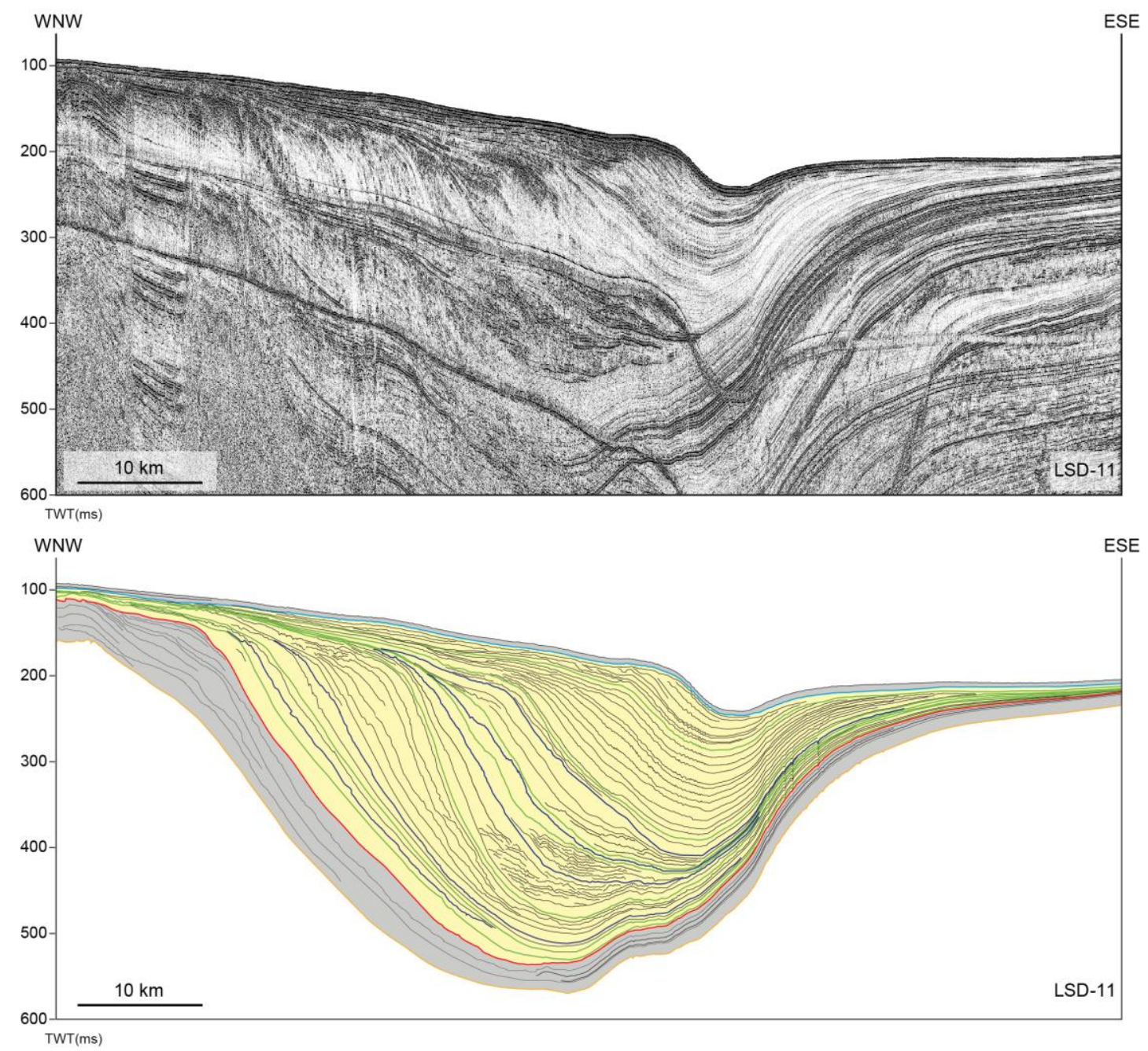

Fig. 3. Line drawing of LSD-11 multichannel profile shows the late Pleistocene Po River lowstand Wedge (PRLW) in yellow. Note that the PRLW is constituted by clinothems with constant bottomset aggradation. 

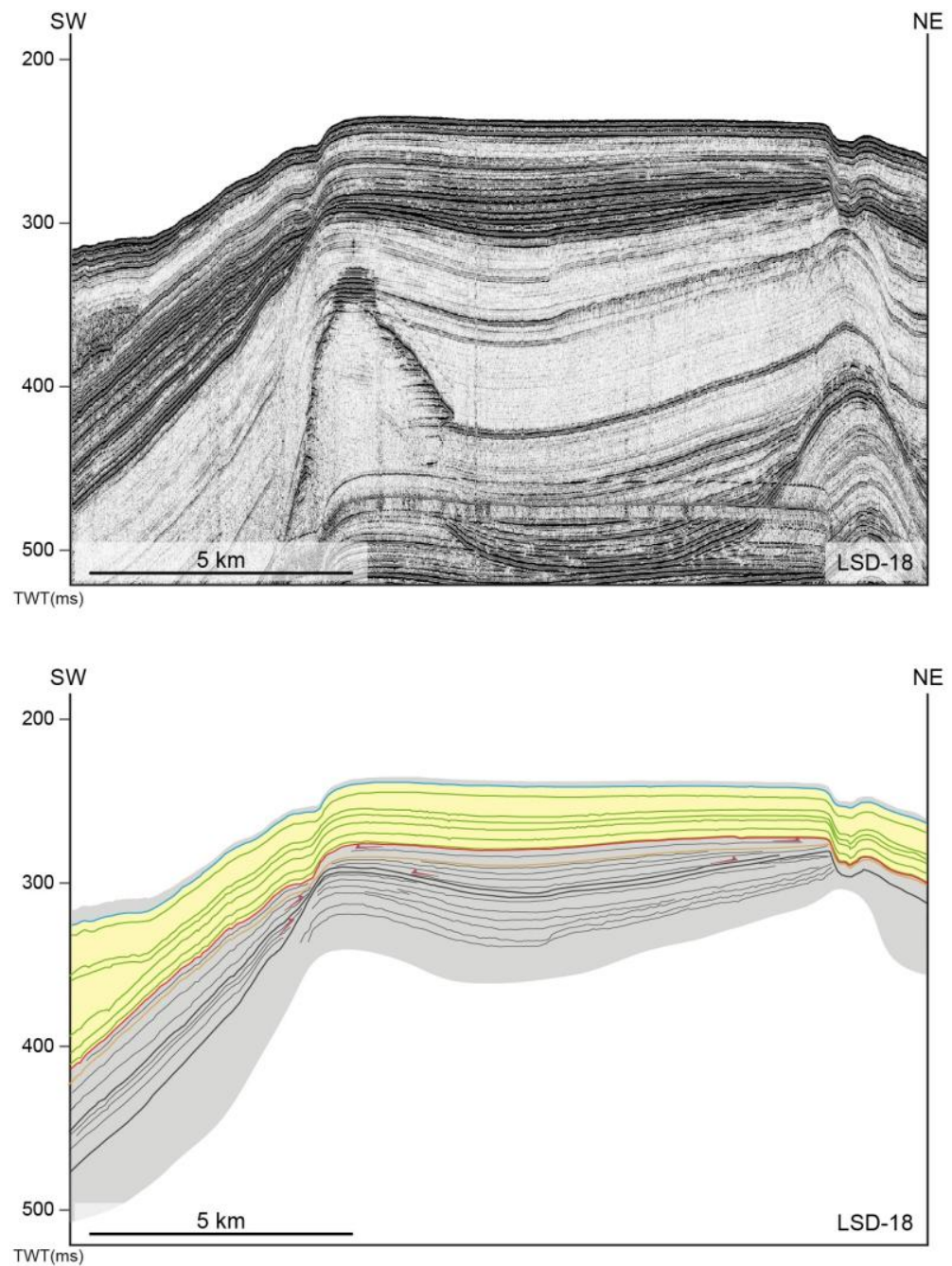

Fig. 4. Multichannel LSD-18 line drawing shows strata terminations suggesting that the tectonic activity is quiescent during the PRLW progradation (yellow interval). 


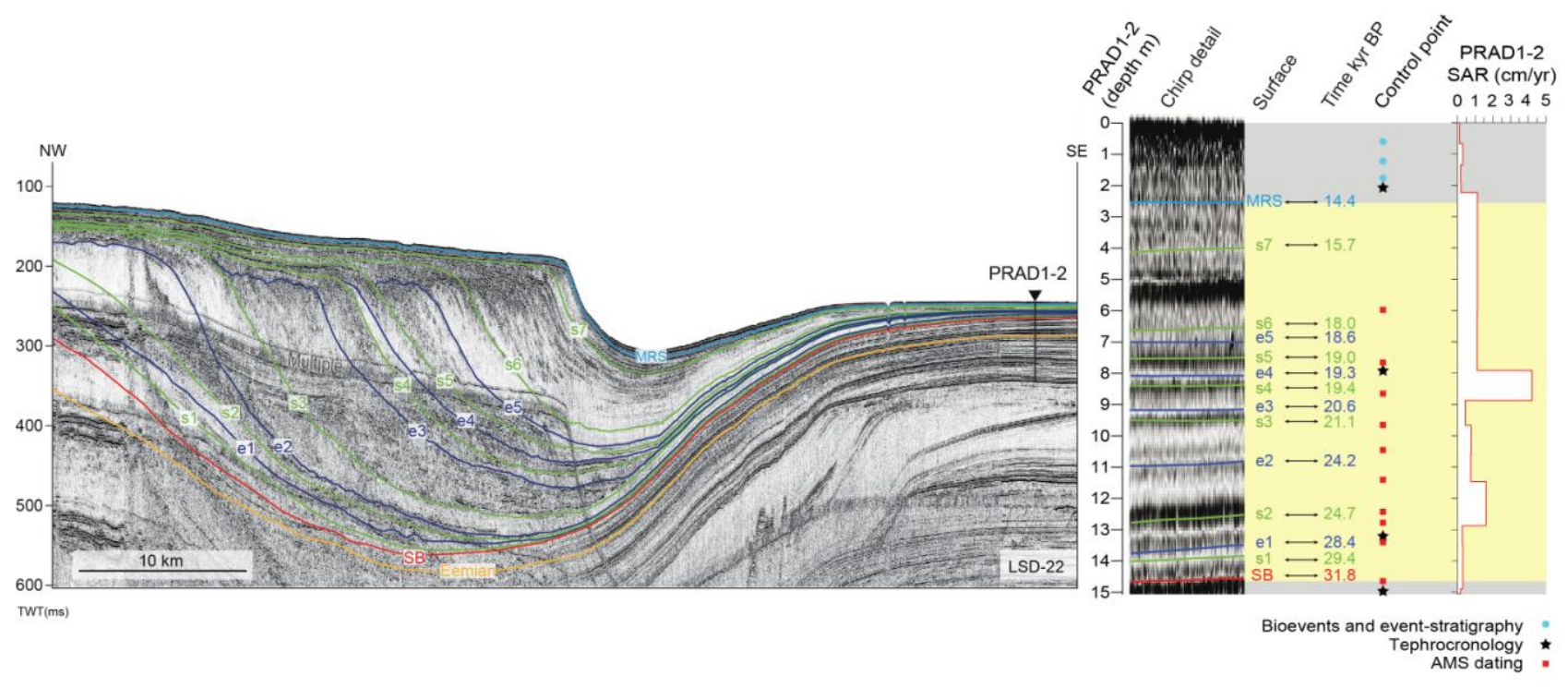

Fig. 5. Downdip multichannel seismic profile LSD-22 illustrates clinothem geometry along the main direction of progradation. The 16 control points and the name and age of seismic horizons are reported along the $15 \mathrm{~m}$ succession. SAR (sediment accumulation rate) is given in $\mathrm{cm} / \mathrm{yr}$. 
Fig. 6. Top: Downdip multichannel seismic profile LSD-13 illustrating clinothem geometries along the main direction of progradation. Bottom: Along-strike profile LSD-04 highlighting the seismic facies of basinal deposits (see figure 1 for seismic lines location). Orange horizon marks top of Eemian (ca. 125 ky BP); red horizon is sequence boundary (SB) at base of Po River Lowstand Wedge (PRLW); green horizons $(s)$ mark surfaces on top of Type A and Type C clinothems whereas blue horizons $(e)$ are on top of Type B clinothems; light blue horizon is the maximum regression surface (MRS) on top of youngest Type $C_{2}$ clinothem (clinothems are numbered from older to younger). Red, orange, and blue dots mark shelf-edge of Type A, B, and C clinothems, respectively. Surface s6 marks transition from progradational clinothem Set 1 (comprising stacked Type A and B clinothems) to aggradational clinothem Set 2 (constituted by stacked Type C clinothems). Insets illustrate distal basin seismic facies associated with Type A (Discontinuous and Low-Amplitude reflections with internal Hyperbolic diffractions, DLAH), Type B (Semicontinuous, High-Amplitude and Mounded reflections, SHAM) and Type C clinothems (High- and Low-Amplitude Continuous reflections, HLAC) in basin. 


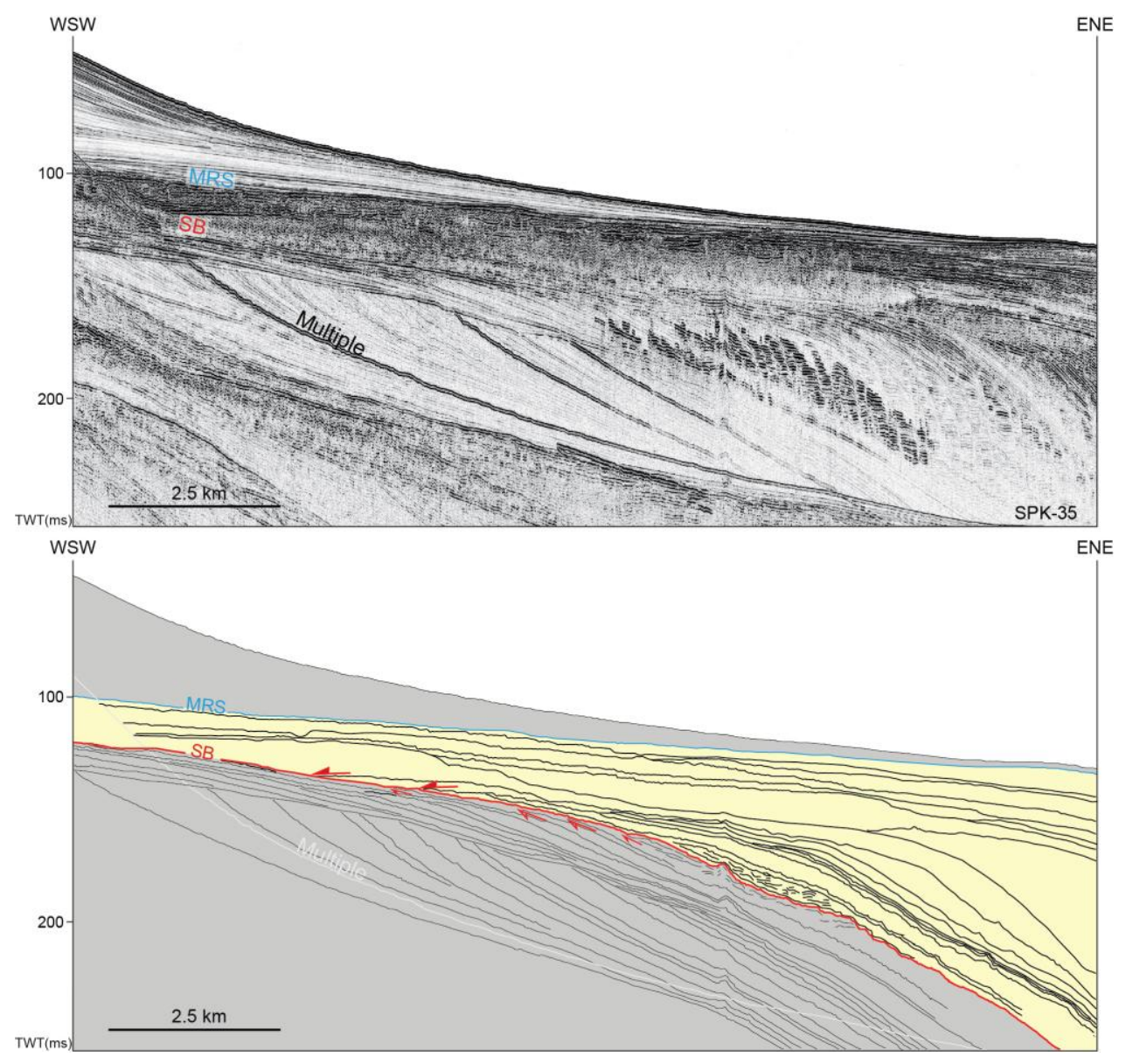

Fig. 7. Detail of the line drawing of SPK-35 sparker profile (along-strike orientation). Seismic terminations highlight the SB at base of the PRLW (yellow interval) with coastal onlap docked close to the shelf-edge. 


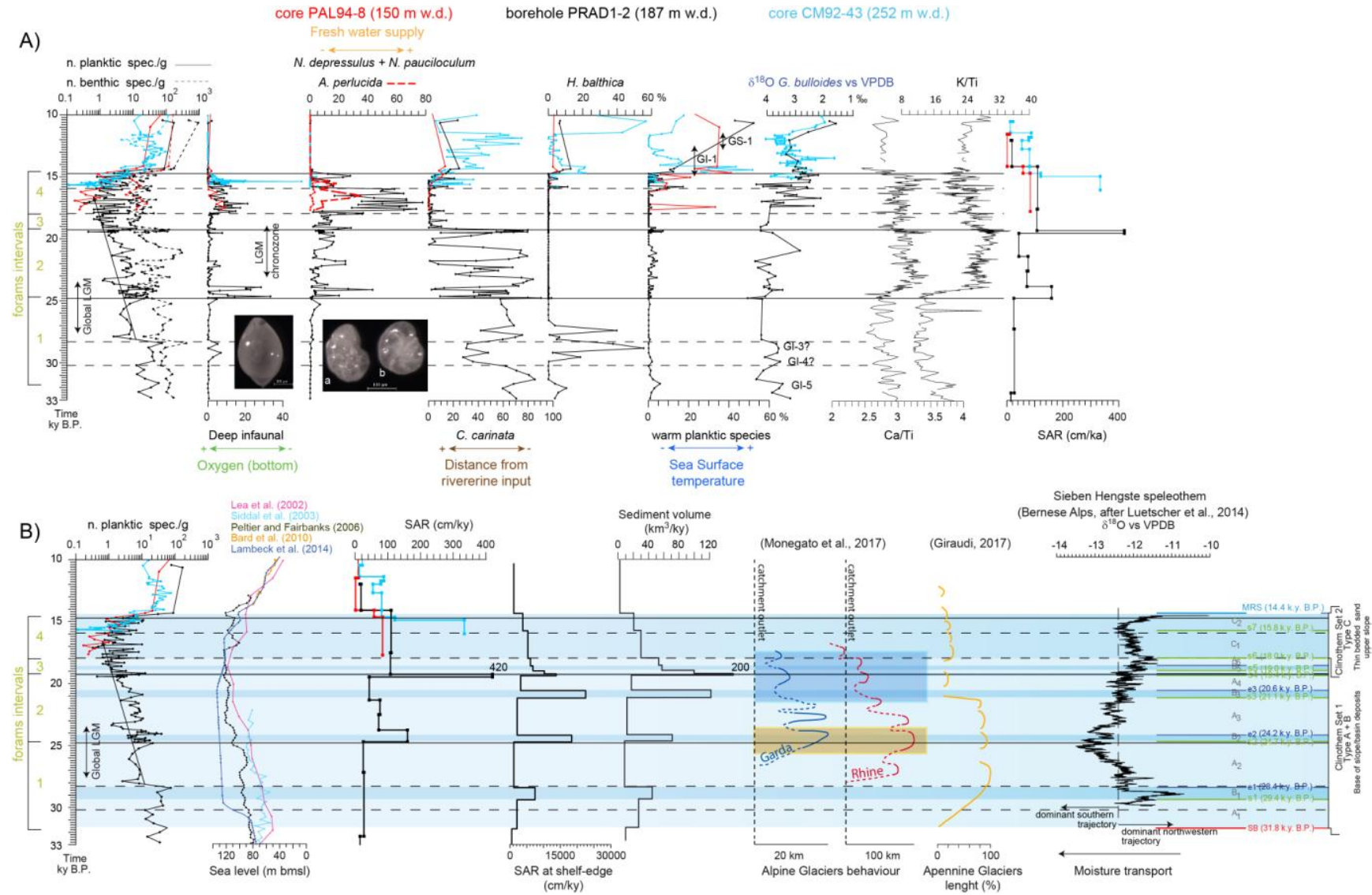

Fig. 8. A) Planktic and benthic foraminifera records of the cores CM92-43 (blue curves) and Pal948 (red curves) and of the borehole PRAD1-2 (black curves) plotted vs age. Note that the foraminifera concentration is plotted in logarithmic scale. The intervals corresponding to the Global LGM and to the LGM Chronozone are also reported. GI-1= Greenland Interstadial 1 (Bolling/Allerod), GS-1= Greenland Stadial 1 (Younger Dryas); B) Planktic and benthic foraminifera records along with eustatic curves, Sediment Accumulation Rate (SAR) from PRAD12 borehole and measured at the shelf-edge, clinothem volumes, curves of advance/retreat (yellow banner represents major culminations and pale-blue banner ice decay) of the Garda and Rhine glaciers relative to the catchment outlet (dashed line; from Monegato et al., 2017), and of the Apennine glaciers (from Giraudi, 2017), and Bernese Alps speleothem record. Time span by foraminifera intervals and type of clinothems are outlined for comparison. 


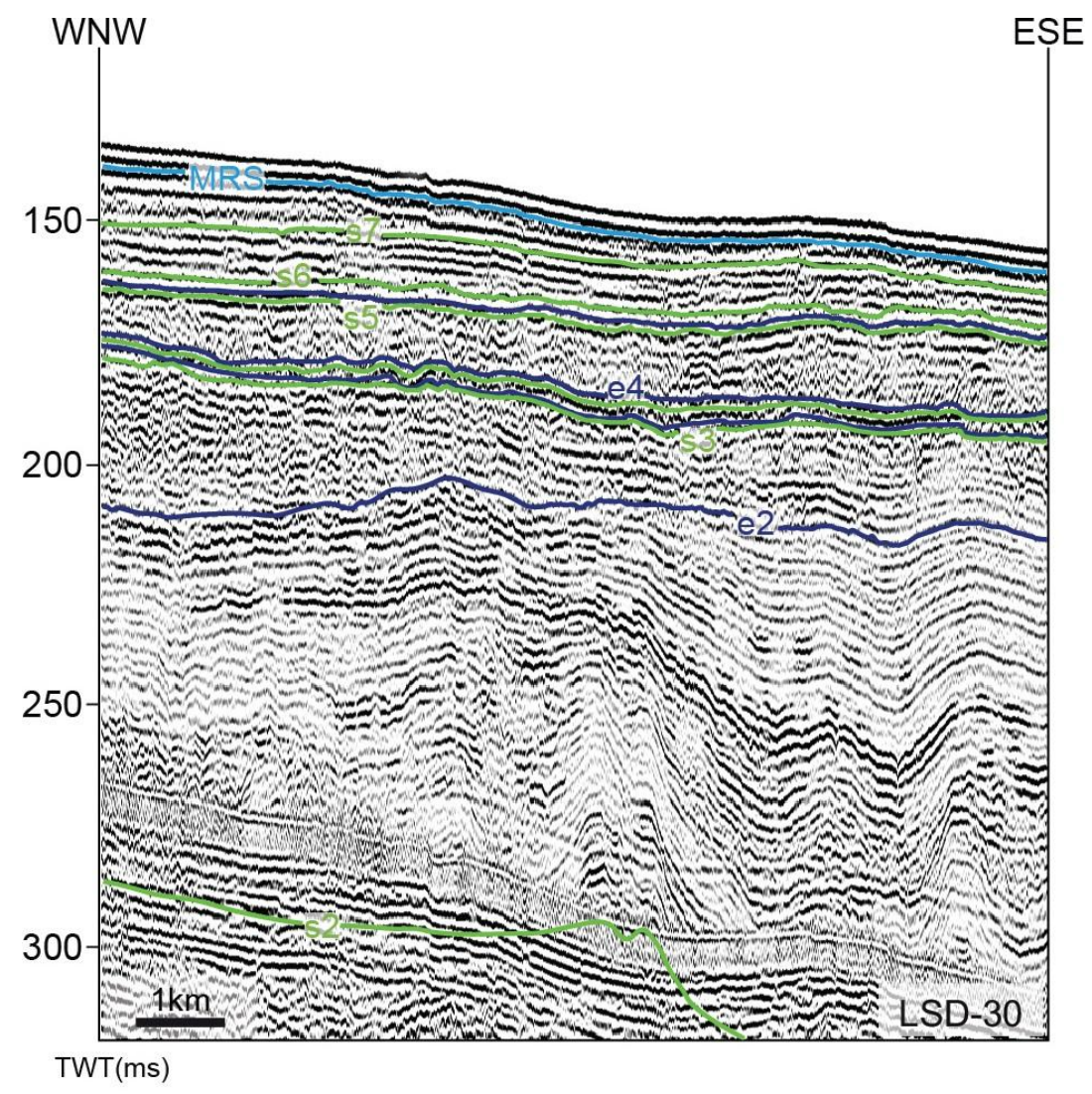

Fig. 9. Detail of LSD-30 multichannel profile with along strike orientation. Note the decreasing in dimensions of feeder systems and valley-related features and seismic unit thickness from the bottom to the top of the succession. Between $\mathrm{s} 2$ and e 2 surfaces sediment strata up to several ten of meters thick show parallel to wedge-shaped high-amplitude reflection packages that pass laterally to lowamplitude reflections reminiscent of turbidite channel-levee complexes in the foreset. 
PRLW thickness between SB and MRS (17 ky)

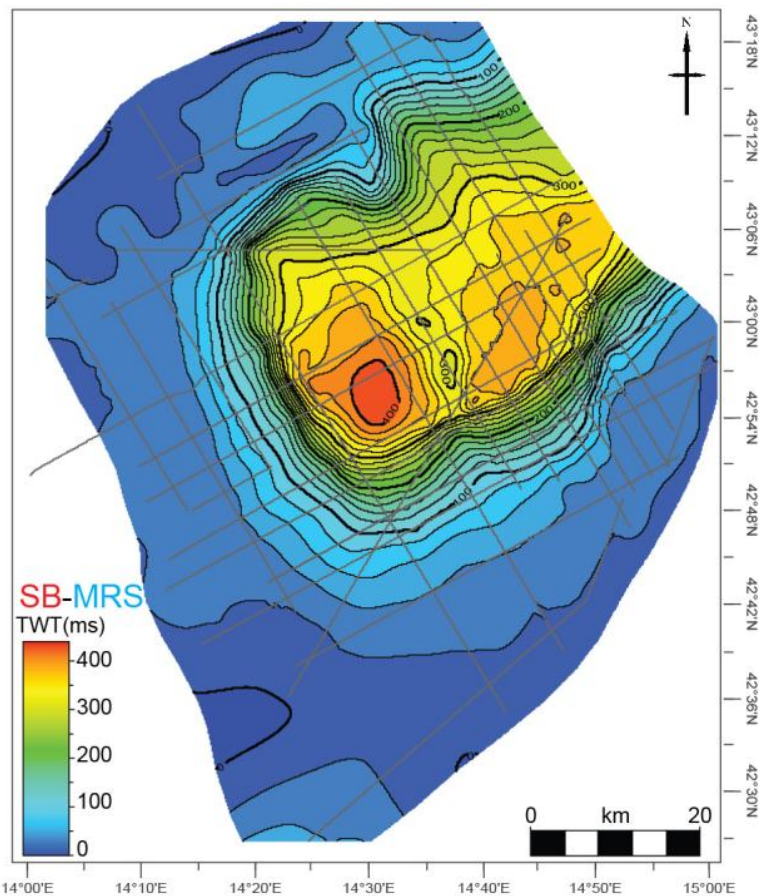

Fig. 10. Structural map of SB surface at $31.8 \mathrm{ky} \mathrm{BP}$ and the thickness map of the PRLW. Darkest color represents the deepest and thinner sector. 

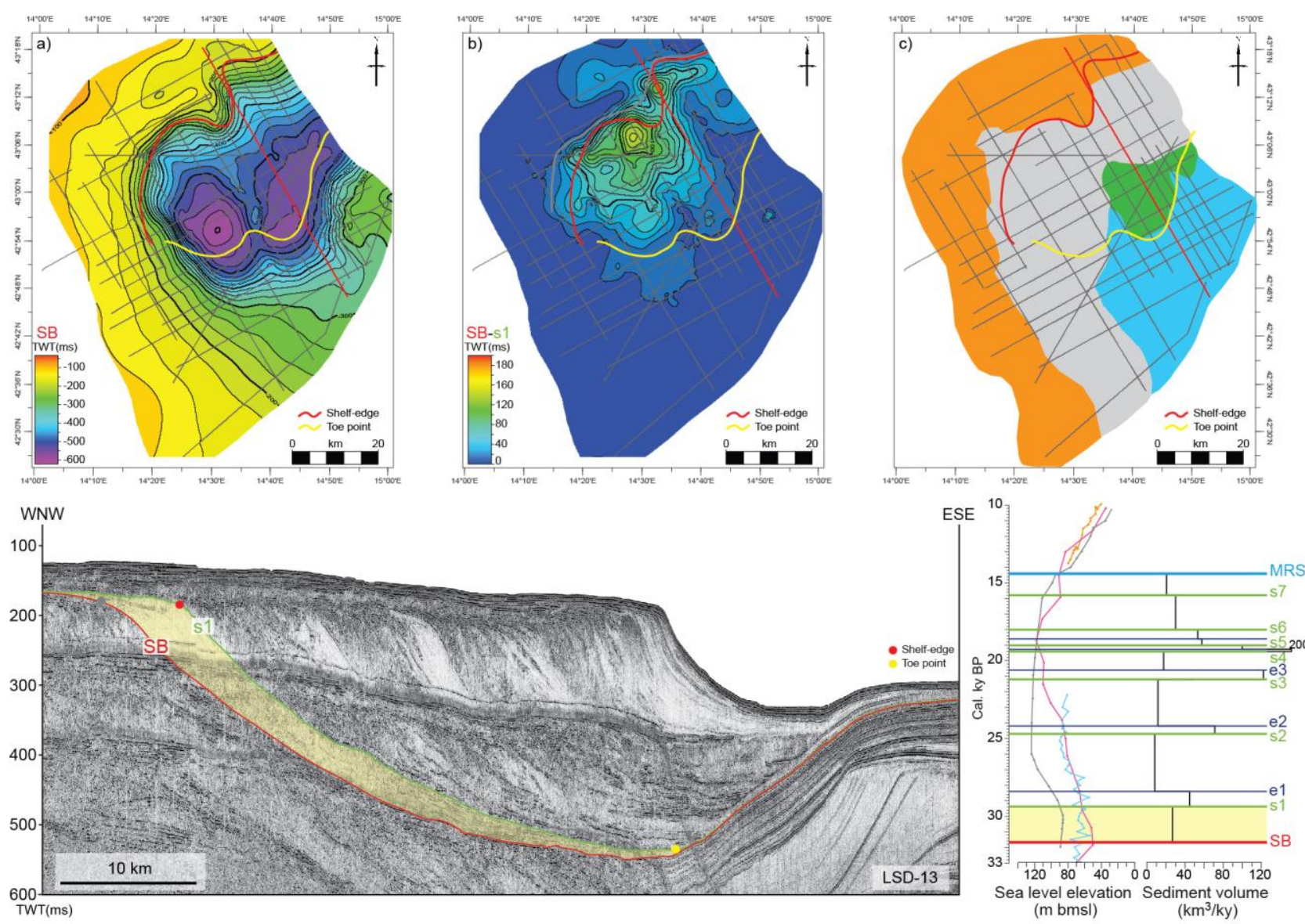

Fig. 11. Clinothem $A_{1}$. Top: a) structural map; b) thickness map; c) seismic facies map (see table 2 for the legend). Bottom: LSD-13 multichannel profile, eustatic curves (purple curve: Lea et al., 2002; light blue: Siddal et al., 2003; black curve: Peltier and Feirbanks, 2006; yellow curve: Bard et al., 2010; blue curve: Lambeck et al., 2014) and sediment volume $\left(\mathrm{km}^{3} / \mathrm{ky}\right)$ are given for each clinothem that constitute the PRLW. 

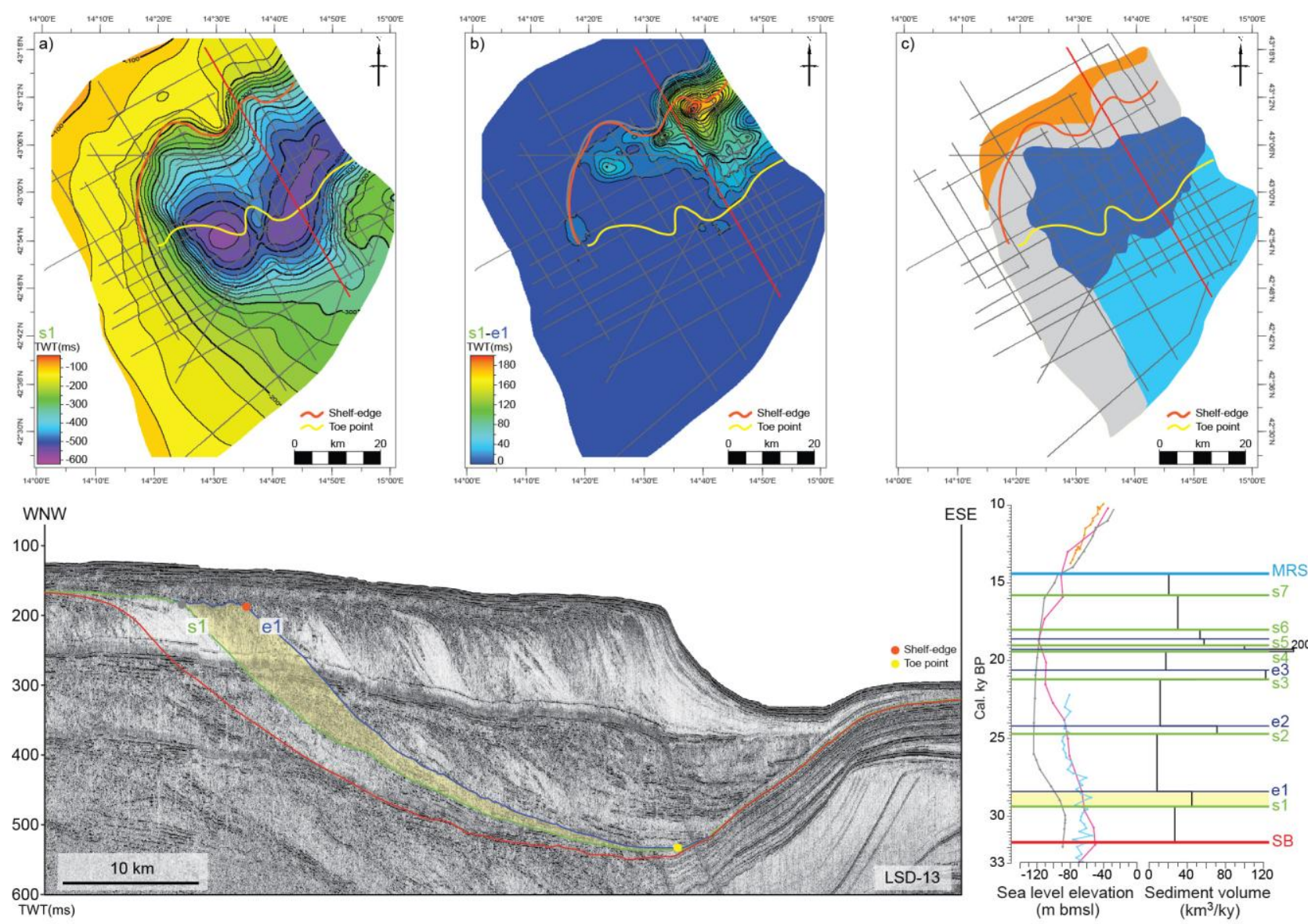

Fig. 12. Clinothem $B_{1}$. Top: a) structural map; b) thickness map; c) seismic facies map (see table 2 for the legend). Bottom: LSD-13 multichannel profile, eustatic curves (purple curve: Lea et al., 2002; light blue: Siddal et al., 2003; black curve: Peltier and Feirbanks, 2006; yellow curve: Bard et al., 2010; blue curve: Lambeck et al., 2014) and sediment volume $\left(\mathrm{km}^{3} / \mathrm{ky}\right)$ are given for each clinothem that constitute the PRLW. 

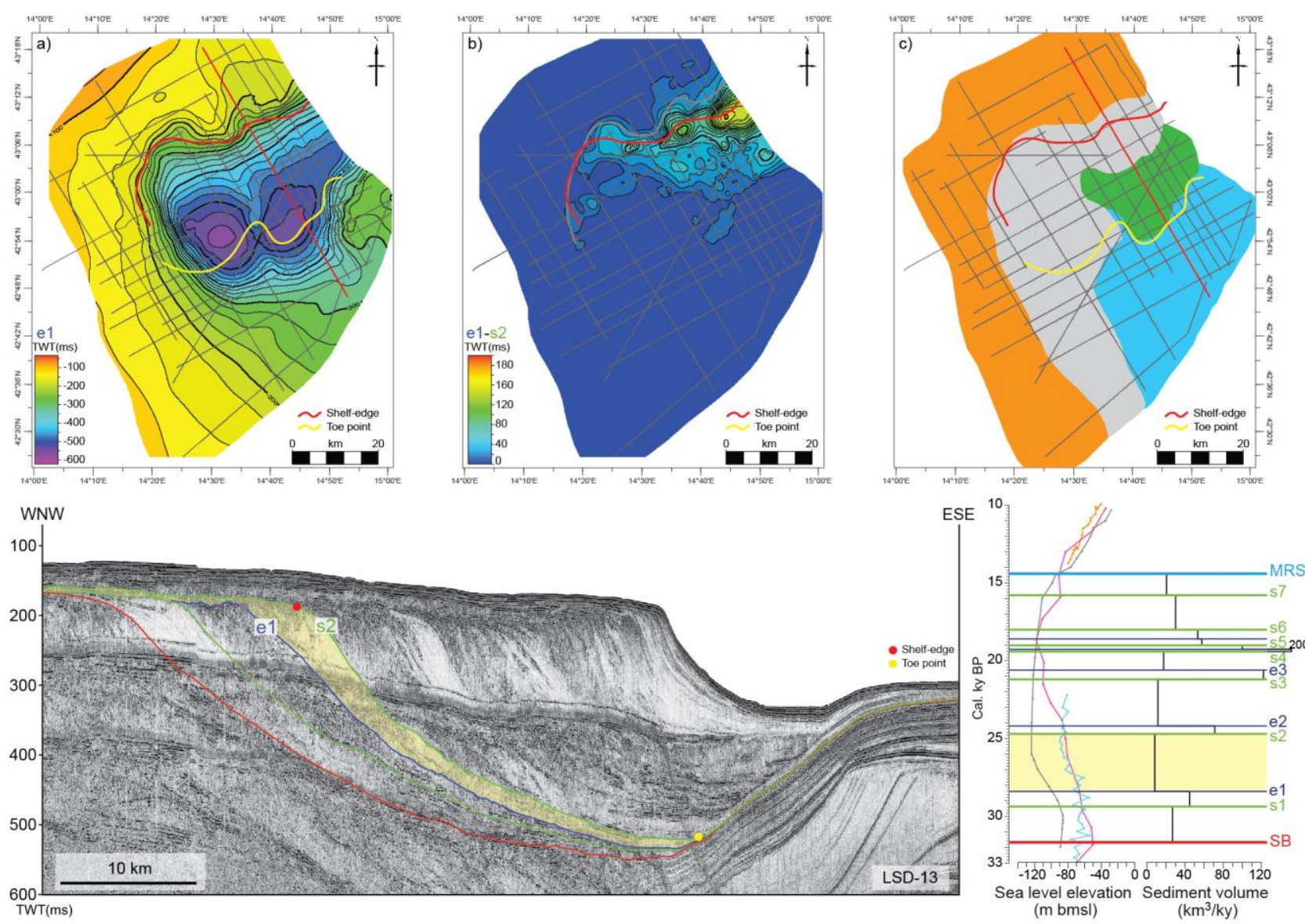

Fig. 13. Clinothem $A_{2}$. Top: a) structural map; b) thickness map; c) seismic facies map (see table 2 for the legend). Bottom: LSD-13 multichannel profile, eustatic curves (purple curve: Lea et al., 2002; light blue: Siddal et al., 2003; black curve: Peltier and Feirbanks, 2006; yellow curve: Bard et al., 2010; blue curve: Lambeck et al., 2014) and sediment volume $\left(\mathrm{km}^{3} / \mathrm{ky}\right)$ are given for each clinothem that constitute the PRLW. 

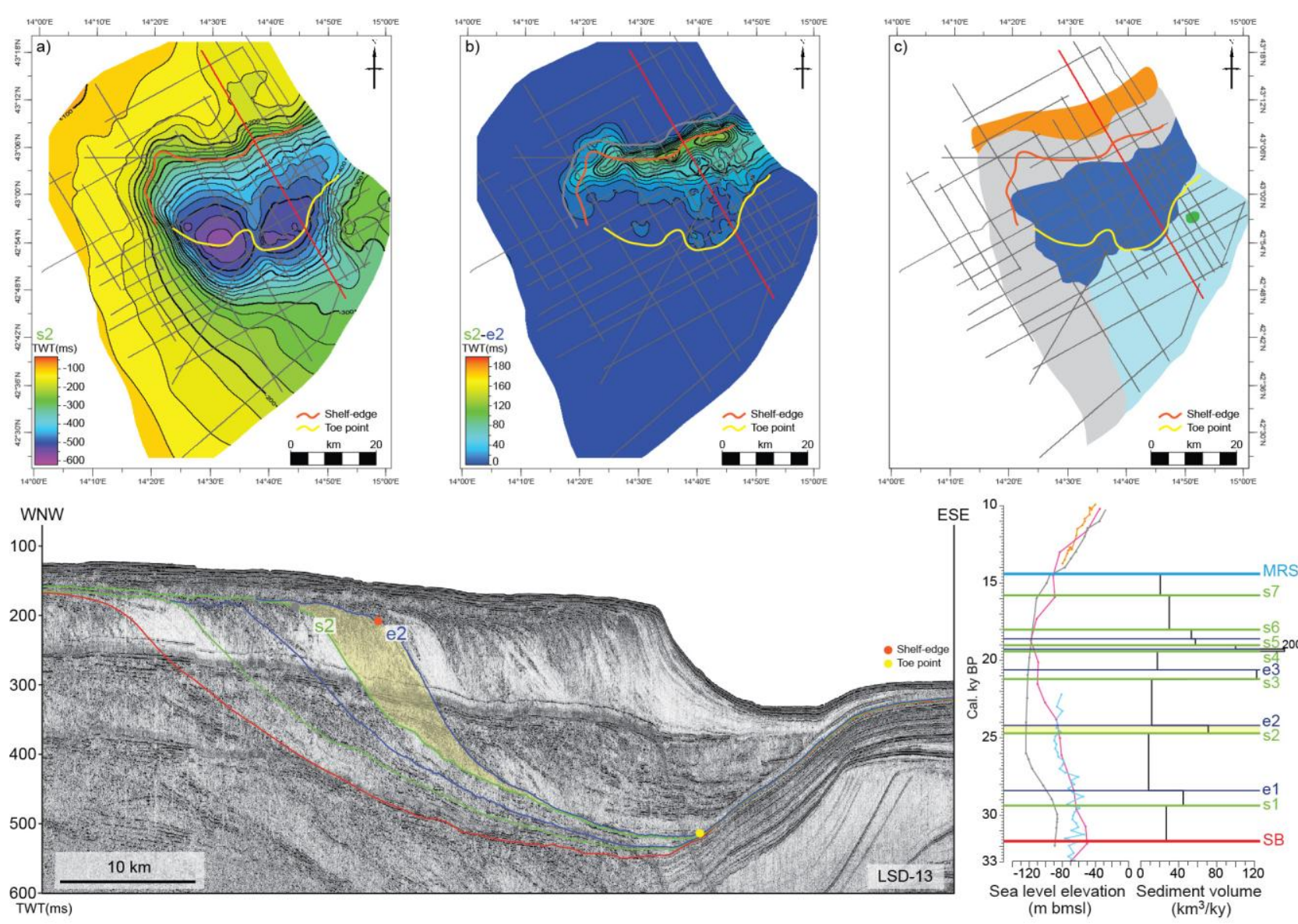

Fig. 14. Clinothem $B_{2}$. Top: a) structural map; b) thickness map; c) seismic facies map (see table 2 for the legend). Bottom: LSD-13 multichannel profile, eustatic curves (purple curve: Lea et al., 2002; light blue: Siddal et al., 2003; black curve: Peltier and Feirbanks, 2006; yellow curve: Bard et al., 2010; blue curve: Lambeck et al., 2014) and sediment volume $\left(\mathrm{km}^{3} / \mathrm{ky}\right)$ are given for each clinothem that constitute the PRLW. 

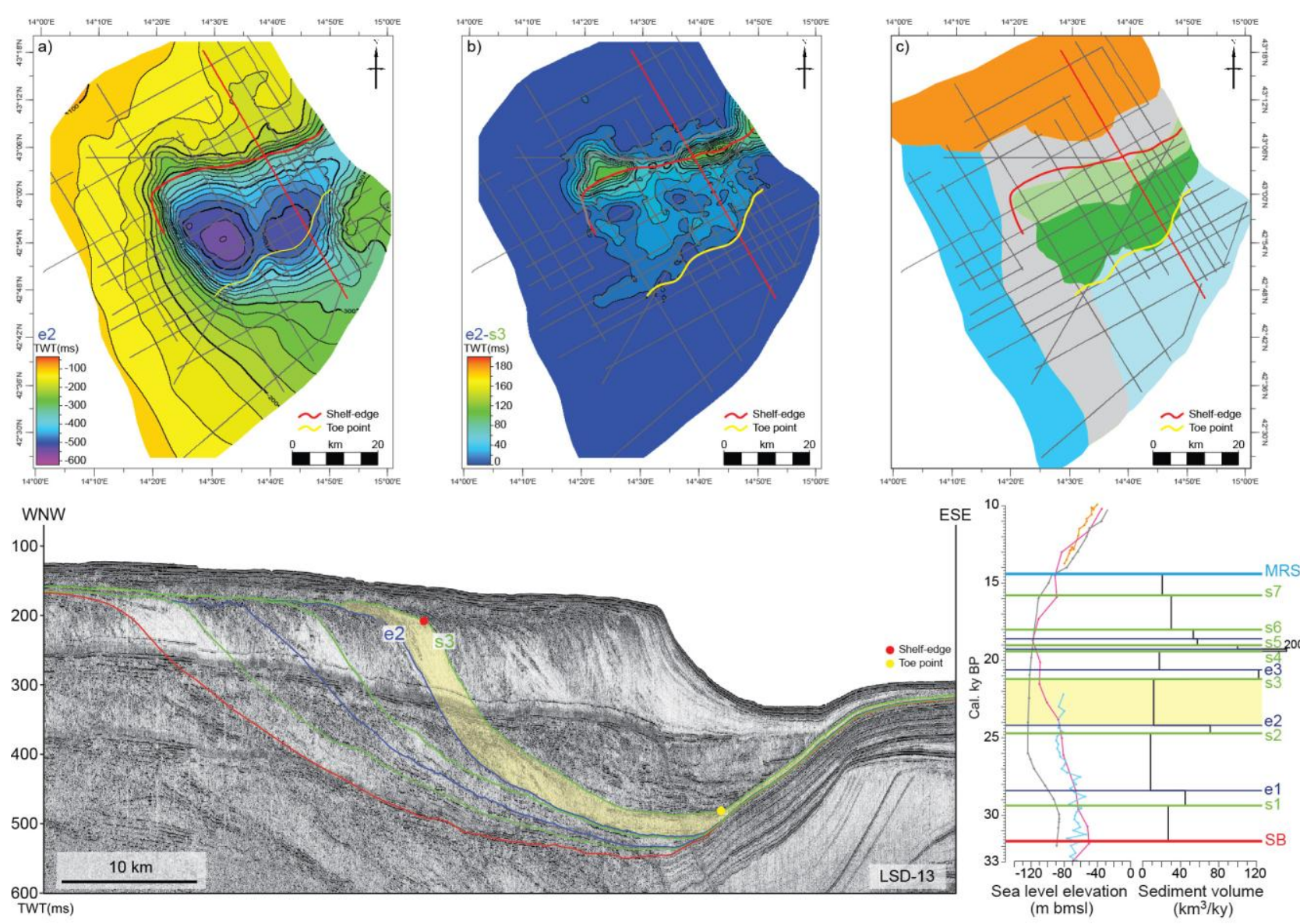

Fig. 15. Clinothem $A_{3}$. Top: a) structural map; b) thickness map; c) seismic facies map (see table 2 for the legend). Bottom: LSD-13 multichannel profile, eustatic curves (purple curve: Lea et al., 2002; light blue: Siddal et al., 2003; black curve: Peltier and Feirbanks, 2006; yellow curve: Bard et al., 2010; blue curve: Lambeck et al., 2014) and sediment volume $\left(\mathrm{km}^{3} / \mathrm{ky}\right)$ are given for each clinothem that constitute the PRLW. 

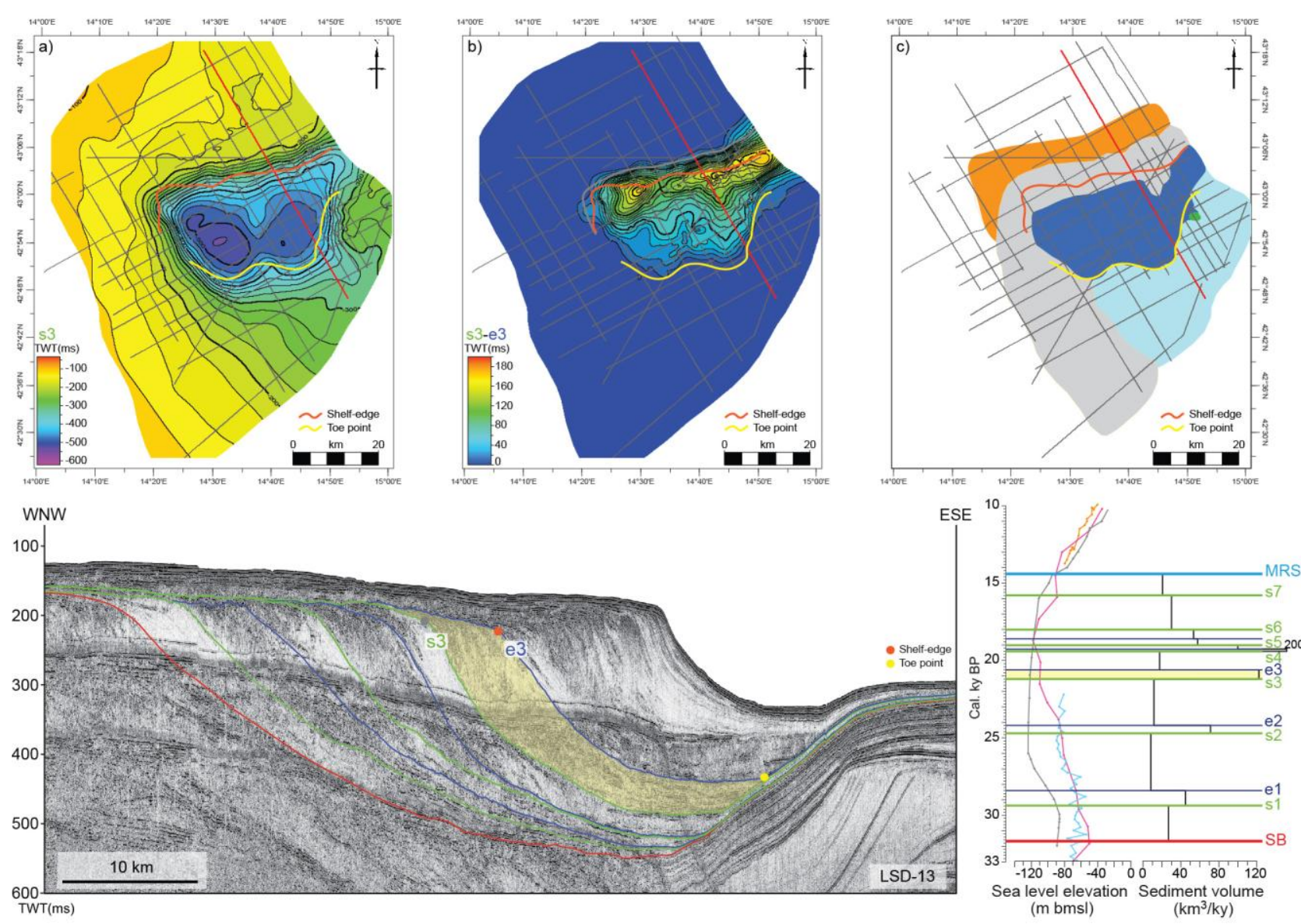

Fig. 16. Clinothem $B_{3}$. Top: a) structural map; b) thickness map; c) seismic facies map (see table 2 for the legend). Bottom: LSD-13 multichannel profile, eustatic curves (purple curve: Lea et al., 2002; light blue: Siddal et al., 2003; black curve: Peltier and Feirbanks, 2006; yellow curve: Bard et al., 2010; blue curve: Lambeck et al., 2014) and sediment volume $\left(\mathrm{km}^{3} / \mathrm{ky}\right)$ are given for each clinothem that constitute the PRLW. 

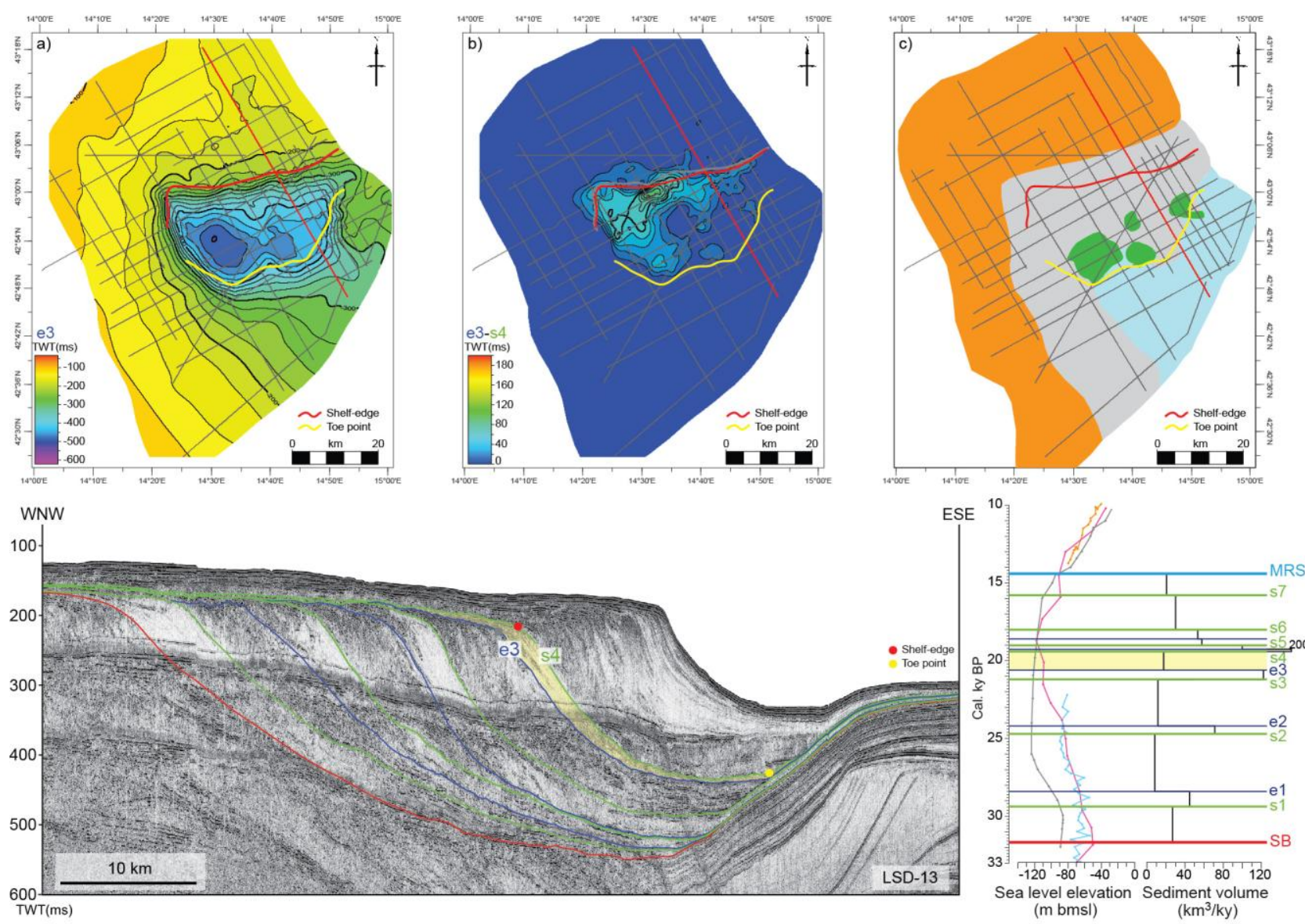

Fig. 17. Clinothem $\mathrm{A}_{4}$. Top: a) structural map; b) thickness map; c) seismic facies map (see table 2 for the legend). Bottom: LSD-13 multichannel profile, eustatic curves (purple curve: Lea et al., 2002; light blue: Siddal et al., 2003; black curve: Peltier and Feirbanks, 2006; yellow curve: Bard et al., 2010; blue curve: Lambeck et al., 2014) and sediment volume $\left(\mathrm{km}^{3} / \mathrm{ky}\right)$ are given for each clinothem that constitute the PRLW. 

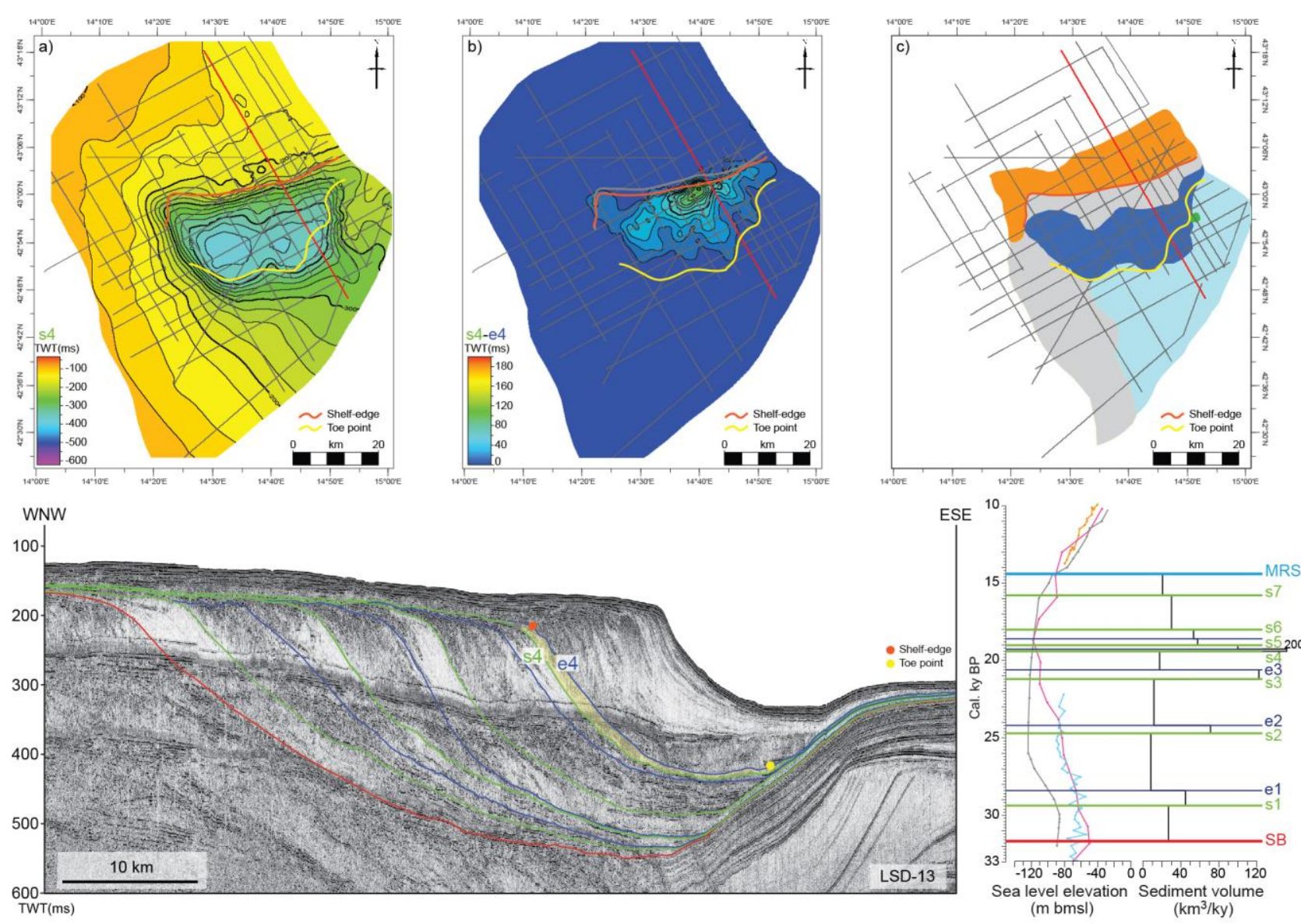

Fig. 18. Clinothem $\mathrm{B}_{4}$. Top: a) structural map; b) thickness map; c) seismic facies map (see table 2 for the legend). Bottom: LSD-13 multichannel profile, eustatic curves (purple curve: Lea et al., 2002; light blue: Siddal et al., 2003; black curve: Peltier and Feirbanks, 2006; yellow curve: Bard et al., 2010; blue curve: Lambeck et al., 2014) and sediment volume $\left(\mathrm{km}^{3} / \mathrm{ky}\right)$ are given for each clinothem that constitute the PRLW. 

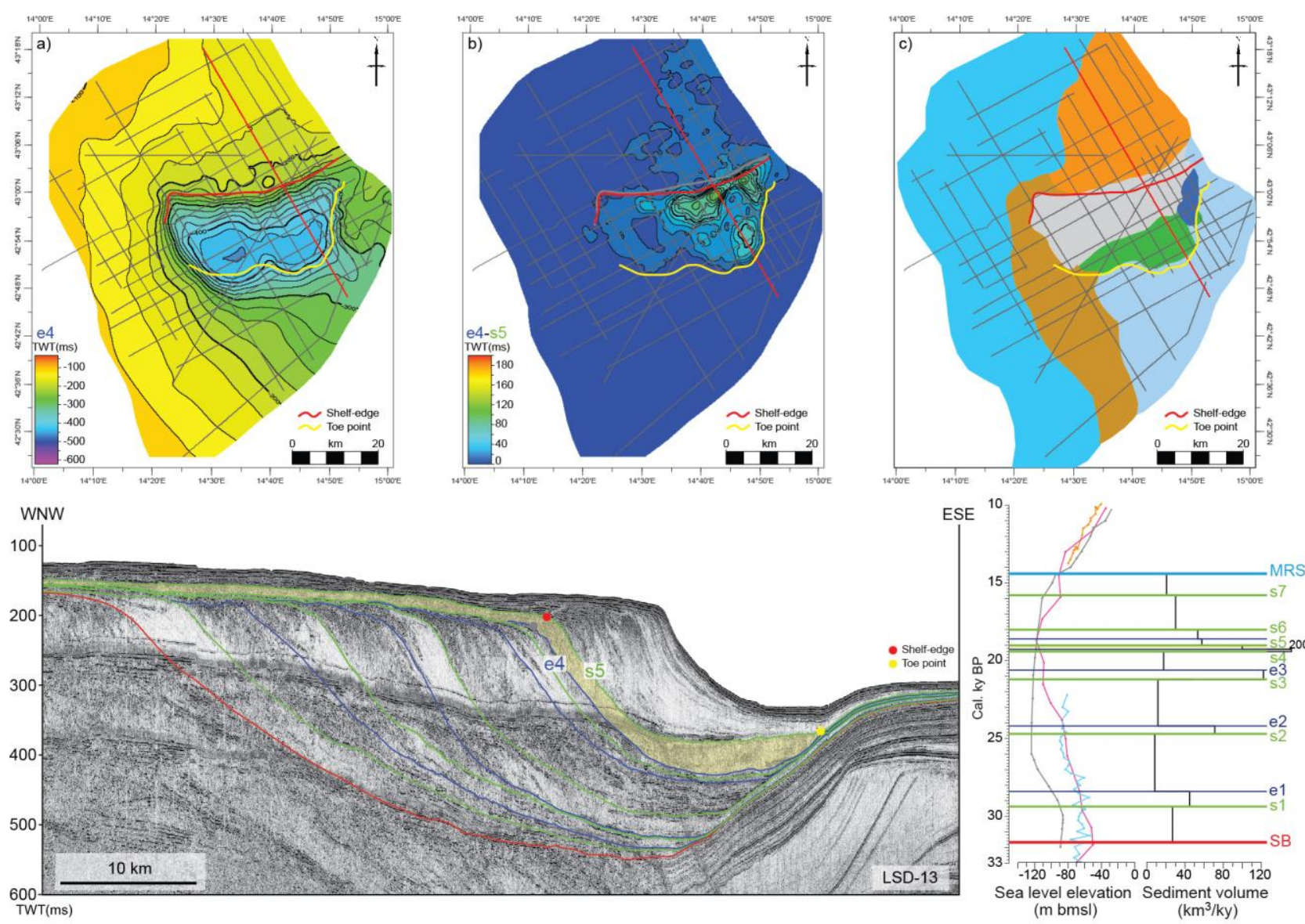

Fig. 19. Clinothem $A_{5}$. Top: a) structural map; b) thickness map; c) seismic facies map (see table 2 for the legend). Bottom: LSD-13 multichannel profile, eustatic curves (purple curve: Lea et al., 2002; light blue: Siddal et al., 2003; black curve: Peltier and Feirbanks, 2006; yellow curve: Bard et al., 2010; blue curve: Lambeck et al., 2014) and sediment volume $\left(\mathrm{km}^{3} / \mathrm{ky}\right)$ are given for each clinothem that constitute the PRLW. 

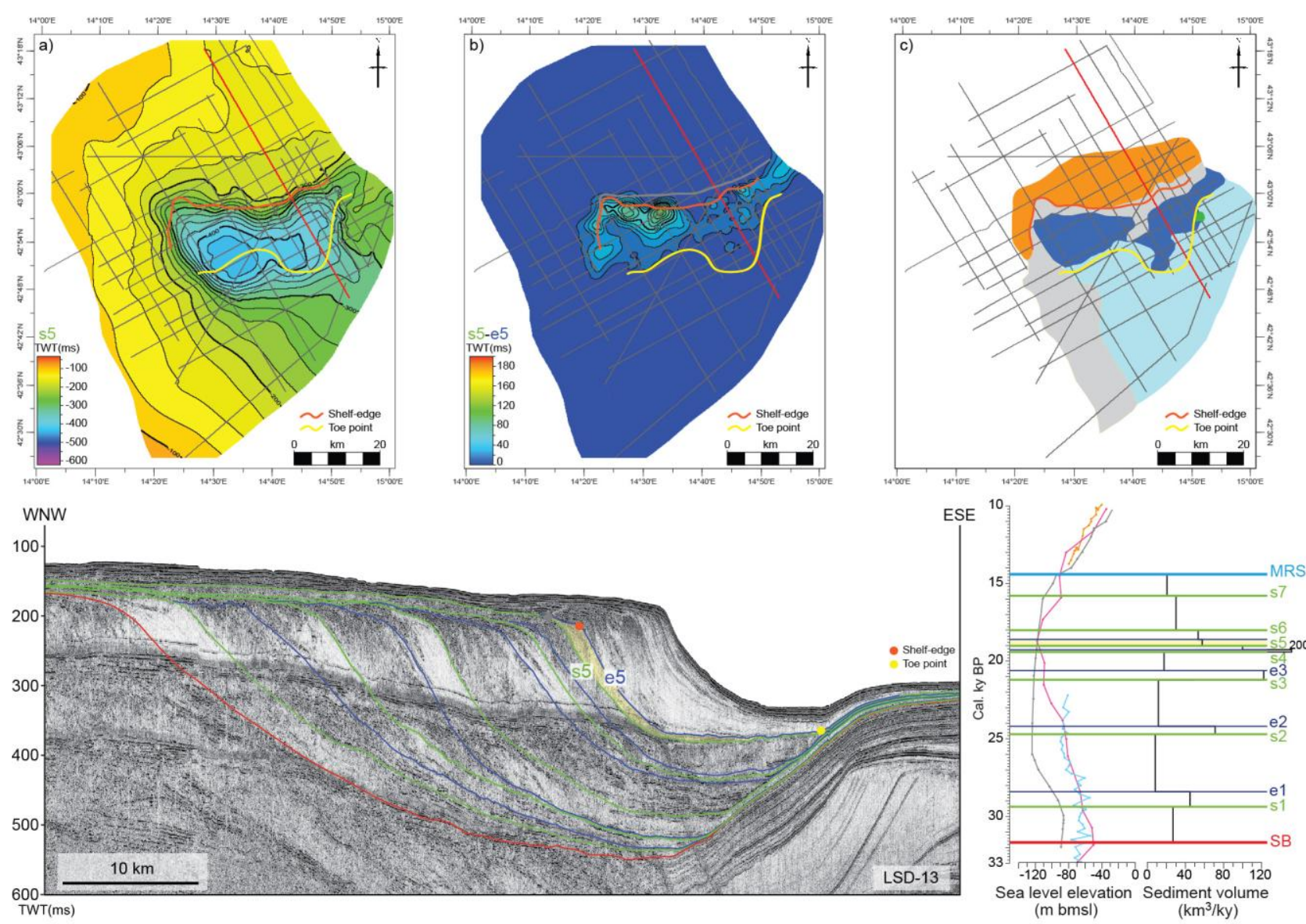

Fig. 20. Clinothem $B_{5}$. Top: a) structural map; b) thickness map; c) seismic facies map (see table 2 for the legend). Bottom: LSD-13 multichannel profile, eustatic curves (purple curve: Lea et al., 2002; light blue: Siddal et al., 2003; black curve: Peltier and Feirbanks, 2006; yellow curve: Bard et al., 2010; blue curve: Lambeck et al., 2014) and sediment volume $\left(\mathrm{km}^{3} / \mathrm{ky}\right)$ are given for each clinothem that constitute the PRLW. 

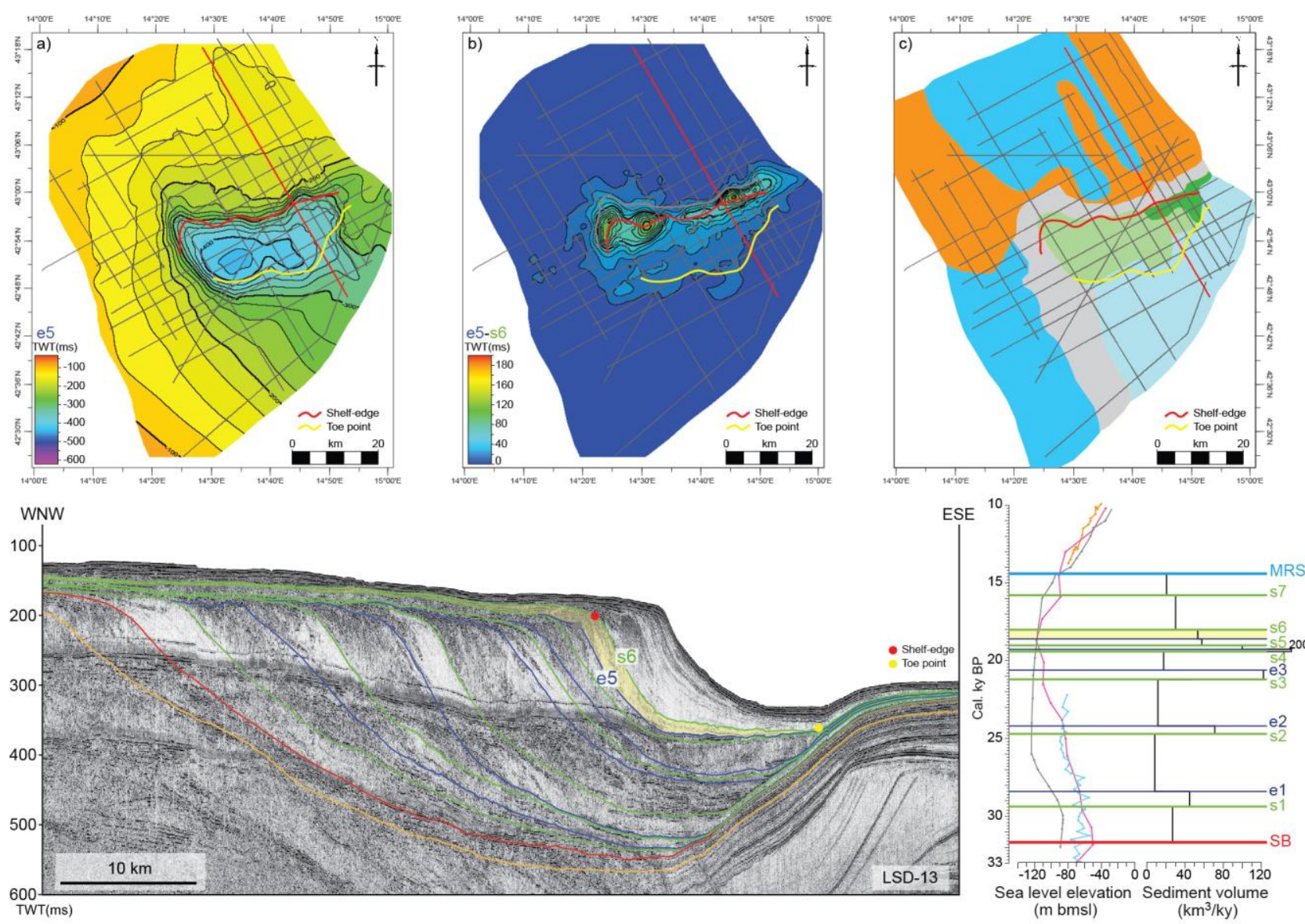

Fig. 21. Clinothem $A_{6}$. Top: a) structural map; b) thickness map; c) seismic facies map (see table 2 for the legend). Bottom: LSD-13 multichannel profile, eustatic curves (purple curve: Lea et al., 2002; light blue: Siddal et al., 2003; black curve: Peltier and Feirbanks, 2006; yellow curve: Bard et al., 2010; blue curve: Lambeck et al., 2014) and sediment volume $\left(\mathrm{km}^{3} / \mathrm{ky}\right)$ are given for each clinothem that constitute the PRLW. 

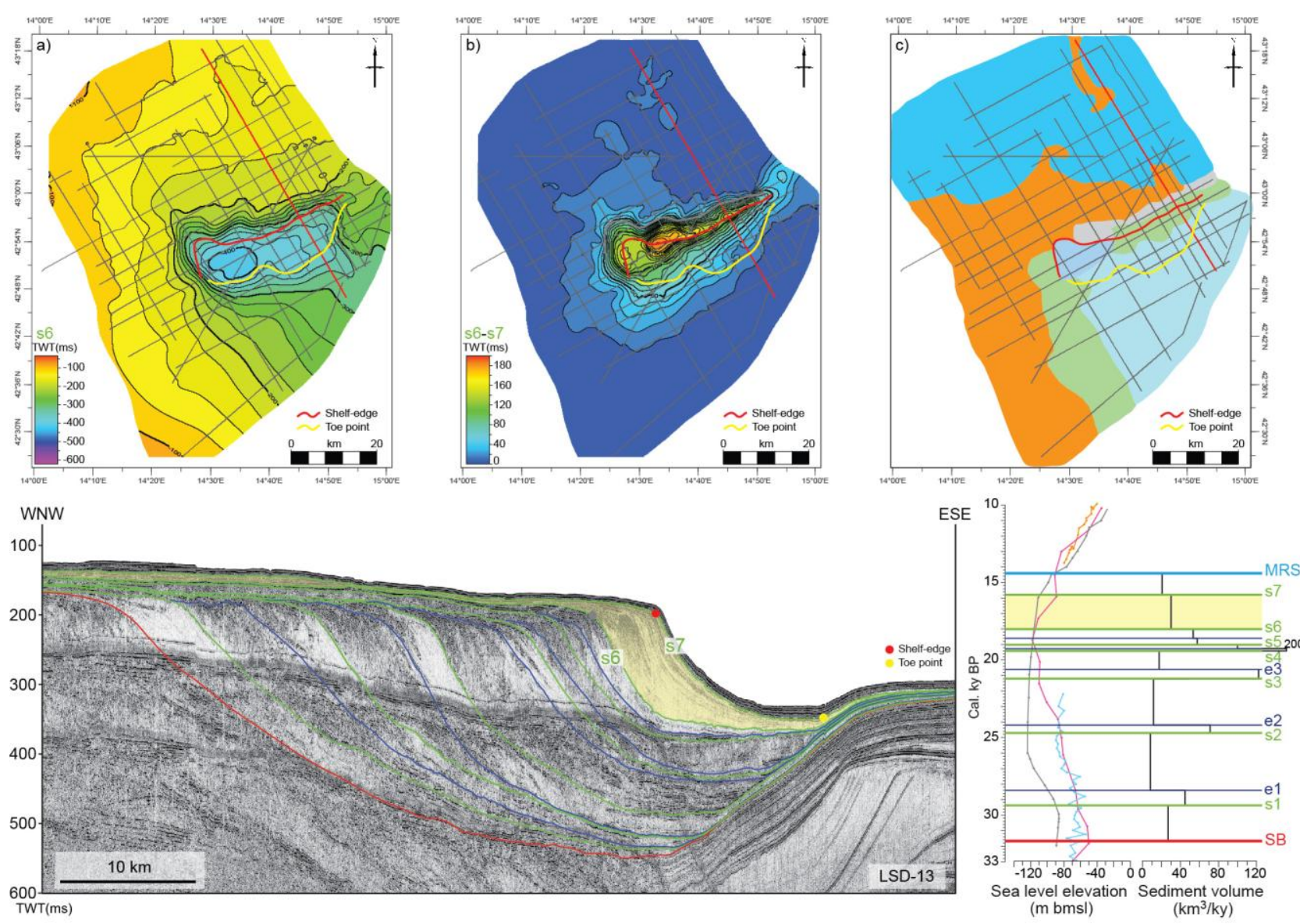

Fig. 22. Clinothem $\mathrm{C}_{1}$. Top: a) structural map; b) thickness map; c) seismic facies map (see table 2 for the legend). Bottom: LSD-13 multichannel profile, eustatic curves (purple curve: Lea et al., 2002; light blue: Siddal et al., 2003; black curve: Peltier and Feirbanks, 2006; yellow curve: Bard et al., 2010; blue curve: Lambeck et al., 2014) and sediment volume $\left(\mathrm{km}^{3} / \mathrm{ky}\right)$ are given for each clinothem that constitute the PRLW. 

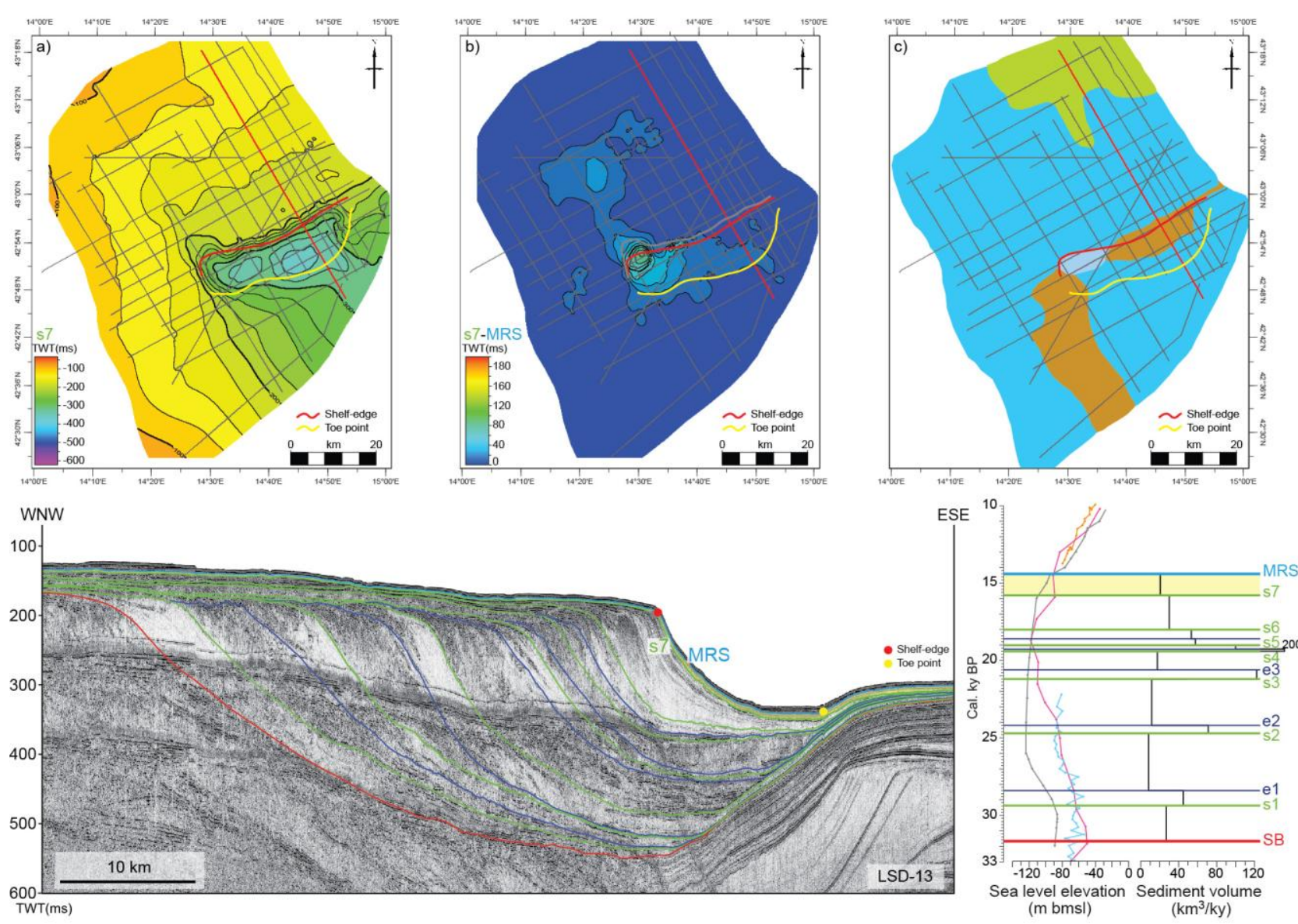

Fig. 23. Clinothem $\mathrm{C}_{2}$. Top: a) structural map; b) thickness map; c) seismic facies map (see table 2 for the legend). Bottom: LSD-13 multichannel profile, eustatic curves (purple curve: Lea et al., 2002; light blue: Siddal et al., 2003; black curve: Peltier and Feirbanks, 2006; yellow curve: Bard et al., 2010; blue curve: Lambeck et al., 2014) and sediment volume $\left(\mathrm{km}^{3} / \mathrm{ky}\right)$ are given for each clinothem that constitute the PRLW. 


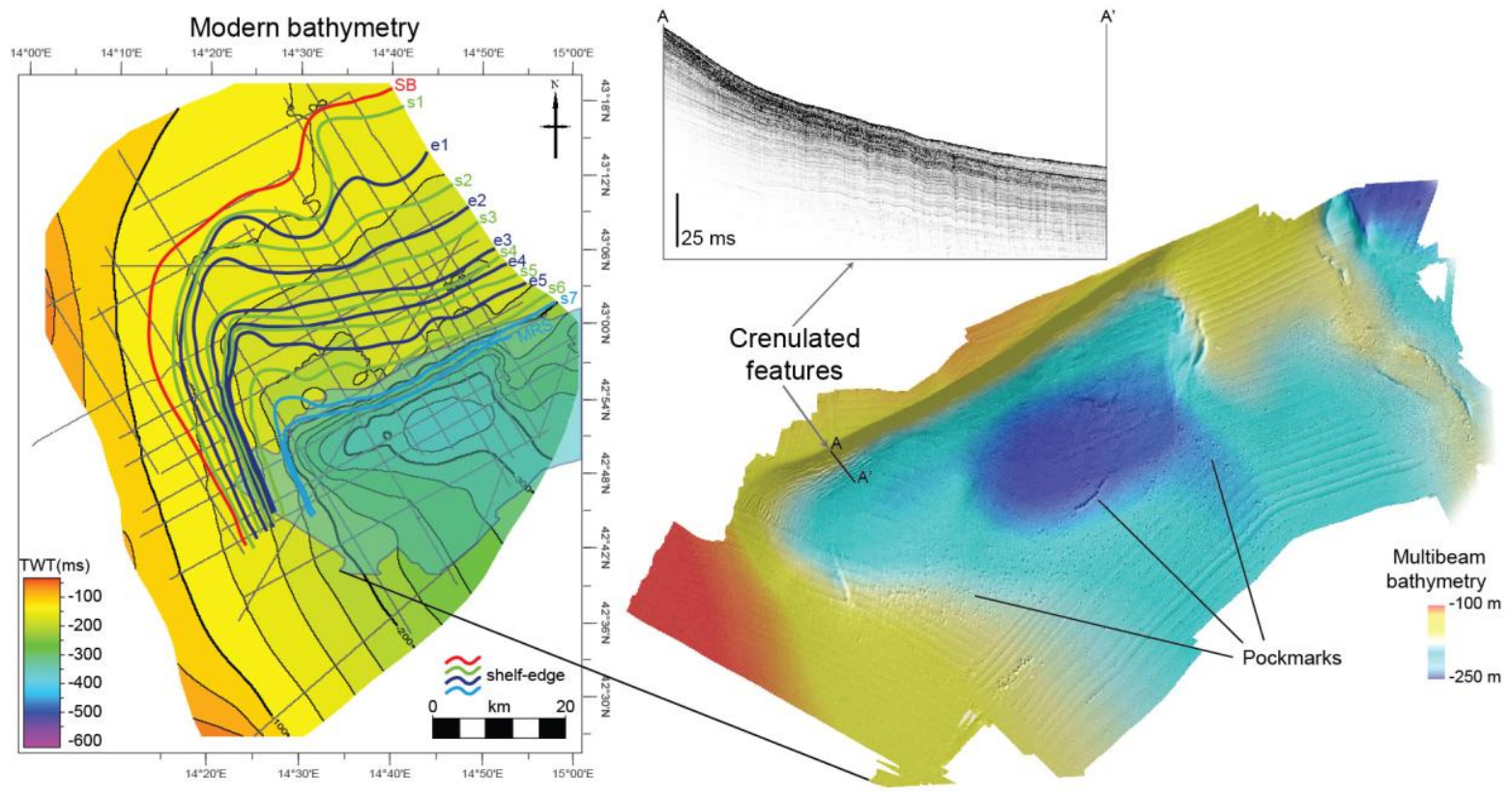

Fig. 24. The modern MAD bathymetry from seismic horizon interpolation with type of clinothems shelf-edge position during the PRLW progradation. The progradation produced a $40 \mathrm{~km}$ southward shift of the shelf-edge along with the burial of MAD antiform. Detail of the modern multibeam bathymetry shows slope-parallel bedforms (crenulation features) and a widespread field of seabed pockmarks. 
d) isolated channels in topset of Type $C$ clinothems

c) isolated incised valleys with internal point-bar migration in topset of Clinothem $A_{5}$
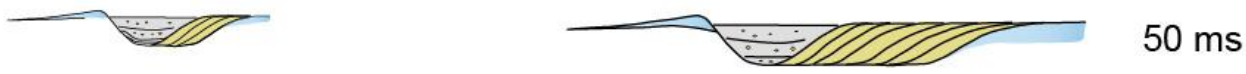

b) extensive amalgamated channel-belt deposits in topset of Clinothem $A_{3}$

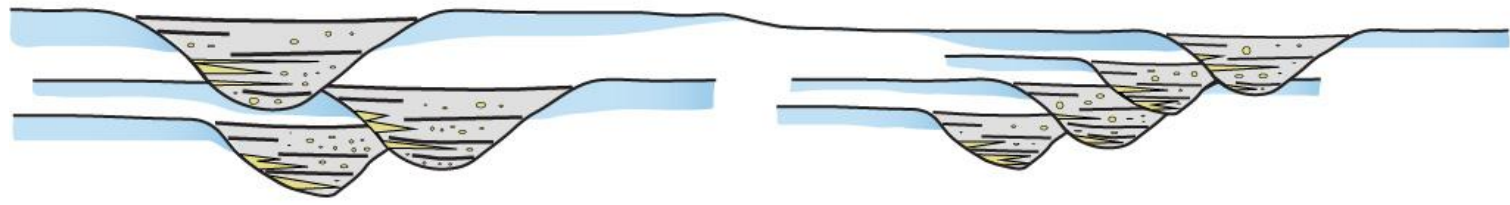

a) large-scale turbidite slope channel-levee complexes in upper foreset of Clinothem $B_{2}$

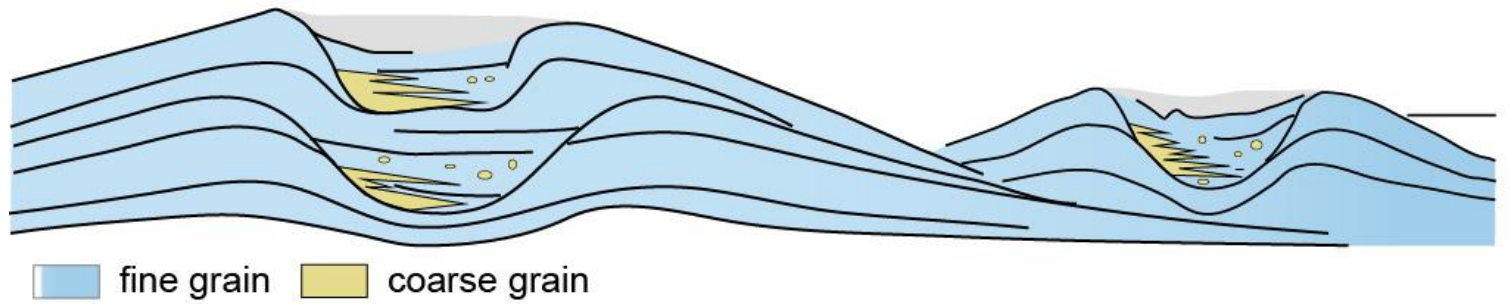

Fig. 25. Cartoon with idealized feeder systems from seismic lines. Note the decreasing in size of the feeder from bottom to the top of the succession and the deepening upward trend showing largescale turbidite channel-levee complexes on the foreset (Clinothem $\mathrm{B}_{2}$ ); extensive acoustically transparent to chaotic units reminiscent of amalgamated channel-belt deposits up to $15 \mathrm{~m}$ thick (Clinothem $\mathrm{A}_{3}$ ); isolated incised valleys with a fill geometry characterized by oblique reflectors that denote point-bar migration (Clinothem $\mathrm{A}_{5}$ ); minor isolated channels, locally accompanied by subdued levees (Clinothem $\mathrm{C}_{2}$ ). During the progradation of the PRLW the main link between shelf and basin is preserved within Type $\mathrm{B}_{2}$ clinothem formed during the eustatic fall, while the most extensive fluvial unit is preserved in the topset of Clinothem $\mathrm{A}_{5}$, deposited at the maximum eustatic lowstand of the last glacial. 
Fig. 26. Conceptual sketch of the type of clinoforms: in Type A clinothem the shoreline is within 10 $\mathrm{km}$ from the shelf-edge, the topset aggrades in the order of $10 \mathrm{~m}$ and margin destabilization is highlighted by MTCs in the basin; in Type B clinothem the shoreline is closer to the shelf-edge $(<5$ $\mathrm{km}$ ) and the topset degradation coupled with directly high amount of sediment bypass to the basin promote the formation of DLCs; in Type C clinothem the shoreline is more than $10 \mathrm{~km}$ from the shelf-edge, and no significant volume of coarse sediment reach the basin floor. 

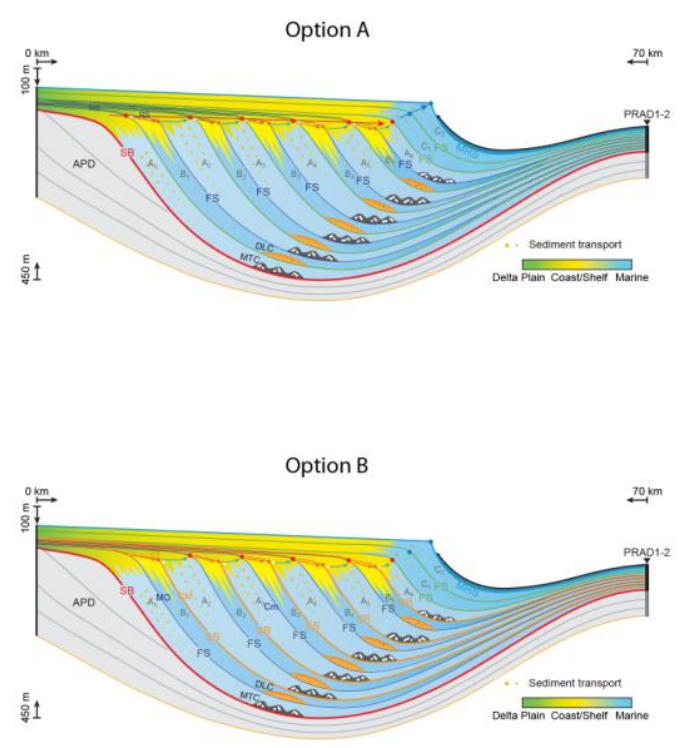
PRLW base-level curve and the timing
of stratal horizon emplacement
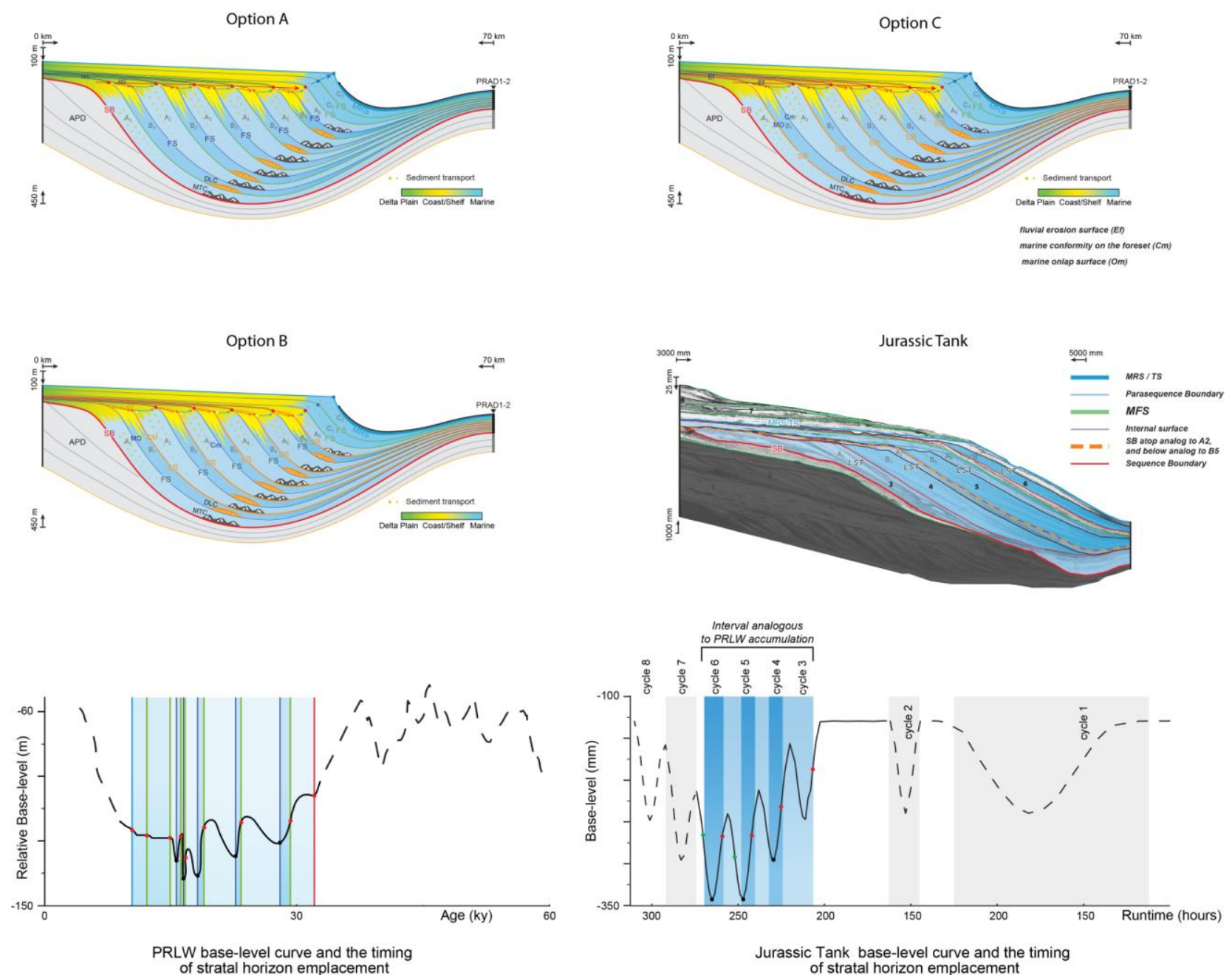

Fig. 27. The three alternative sequence stratigraphic hypothesis. Option A, high-frequency parasequences based on Van Wagoner et al. (1990); Option B, high-frequency sequences and highfrequency transgressive sequences based on Mitchum and Van Wagoner (1990); Option C, highfrequency sequences and parasequences based on Mitchum et al. (1977) and Mitchum and Van Wagoner (1990), respectively. Option C shows a close similarity of accommodation cyclicity and stacking pattern between the PRLW and the Jurassic Tank. 


\begin{tabular}{|c|c|c|c|c|}
\hline $\begin{array}{l}\text { Sample } \\
\text { top }(\mathrm{m})\end{array}$ & Control points & Source & Reference & Status \\
\hline \multicolumn{5}{|l|}{ PRAD1-2 } \\
\hline 0 & 0 & modern time & Pellegrini et al. (2017) & \\
\hline 0.6 & 6000 & LO G. inflata & Pellegrini et al. (2017) & \\
\hline 1.288 & 8500 & Sapropel equivalent 1 & Pellegrini et al. (2017) & \\
\hline 1.8 & 12000 & Top GS-1 & Pellegrini et al. (2017) & \\
\hline 2.18 & 14110 & $\begin{array}{c}\text { Neapolitan Yellow } \\
\text { Tuff }\end{array}$ & Pellegrini et al. (2017) & \\
\hline 5.976 & 17540 & ${ }^{14} \mathrm{C}$ & Pellegrini et al. (2017) & \\
\hline 7.82 & 19275 & $\begin{array}{l}{ }^{14} \mathrm{C}+ \\
\text { Greenish/Verdoline }\end{array}$ & Pellegrini et al. (2017) & \\
\hline 8.8 & 19498 & ${ }^{14} \mathrm{C}$ & Pellegrini et al. (2017) & \\
\hline 9.6 & 21350 & ${ }^{14} \mathrm{C}$ & Pellegrini et al. (2017) & \\
\hline 10.50 & 22528 & ${ }^{14} \mathrm{C}$ & Pellegrini et al. (2017) & \\
\hline 11.40 & 23780 & ${ }^{14} \mathrm{C}$ & Pellegrini et al. (2017) & \\
\hline 12.78 & 24725 & ${ }^{14} \mathrm{C}$ & Pellegrini et al. (2017) & \\
\hline 13.36 & 27200 & $\mathrm{VRa}+{ }^{14} \mathrm{C}$ & Pellegrini et al. (2017) & \\
\hline 14.8 & 32350 & ${ }^{14} \mathrm{C}$ & Pellegrini et al. (2017) & \\
\hline 14.94 & 33300 & Codola (base) & Pellegrini et al. (2017) & \\
\hline 16.53 & 39500 & Campanian Ignimbrite & Pellegrini et al. (2017) & \\
\hline \multicolumn{5}{|l|}{ PAL94-8 } \\
\hline $1.78-1.82$ & $8631-9074$ & ${ }^{14} \mathrm{C}$ & Asioli (1996) & accepted \\
\hline 2.05 & 11500 & Top GS & Asioli et al. (2001) & accepted \\
\hline 2.08 & 14110 & $\begin{array}{c}\text { Neapolitan Yellow } \\
\text { Tuff }\end{array}$ & Calanchi et al. (2008) & rejected \\
\hline $2.28-2.32$ & $13350-13742$ & ${ }^{14} \mathrm{C}$ & Asioli (1996) & rejected \\
\hline $2.40-2.41$ & 14653 & $\begin{array}{l}\text { Abrupt increase of } G \text {. } \\
\text { ruber at base of GI-1 }\end{array}$ & $\begin{array}{l}\text { Asioli (1996); Asioli } \\
\text { et al. (2001) }\end{array}$ & accepted \\
\hline $3.53-3.54$ & 16002 (interpolated) & Y1 tephra & Calanchi et al. (2008) & accepted \\
\hline $4.64-4.68$ & $17169-17695$ & ${ }^{14} \mathrm{C}$ & Asioli (1996) & accepted \\
\hline \multicolumn{5}{|l|}{ CM92-43 } \\
\hline 3.90 & 10480 & ${ }^{14} \mathrm{C}$ & Asioli et al. (2001) & accepted \\
\hline 3.98 & 11390 & ${ }^{14} \mathrm{C}$ & Asioli et al. (2001) & accepted \\
\hline 4.33 & 11750 & ${ }^{14} \mathrm{C}$ & Asioli et al. (2001) & accepted \\
\hline 4.53 & 12005 & ${ }^{14} \mathrm{C}$ & Asioli et al. (2001) & accepted \\
\hline 4.93 & 12700 & ${ }^{14} \mathrm{C}$ & Asioli et al. (2001) & accepted \\
\hline 6.05 & 14110 & $\begin{array}{c}\text { Neapolitan Yellow } \\
\text { Tuff }\end{array}$ & (Bourne et al., 2010) & accepted \\
\hline 6.50 & 14653 & $\begin{array}{l}\text { Abrupt increase of } G \text {. } \\
\text { ruber at base of GI-1 }\end{array}$ & Asioli et al. (2001) & accepted \\
\hline 6.80 & 14900 & $\delta^{18} \mathrm{O}$ stratigraphy TI A & Asioli et al. (2001) & accepted \\
\hline 10.48 & 16002 & (from core Pal94-8) & this study & accepted \\
\hline
\end{tabular}

Tab. 1. The age model for the PRLW succession based on PRAD1-2 borehole, PAL94-8 and CM92-43 sediment cores (see supplemental material) and encompassing ${ }^{14} \mathrm{C}$ dates, tephra layers, bio and stratigraphic events. 


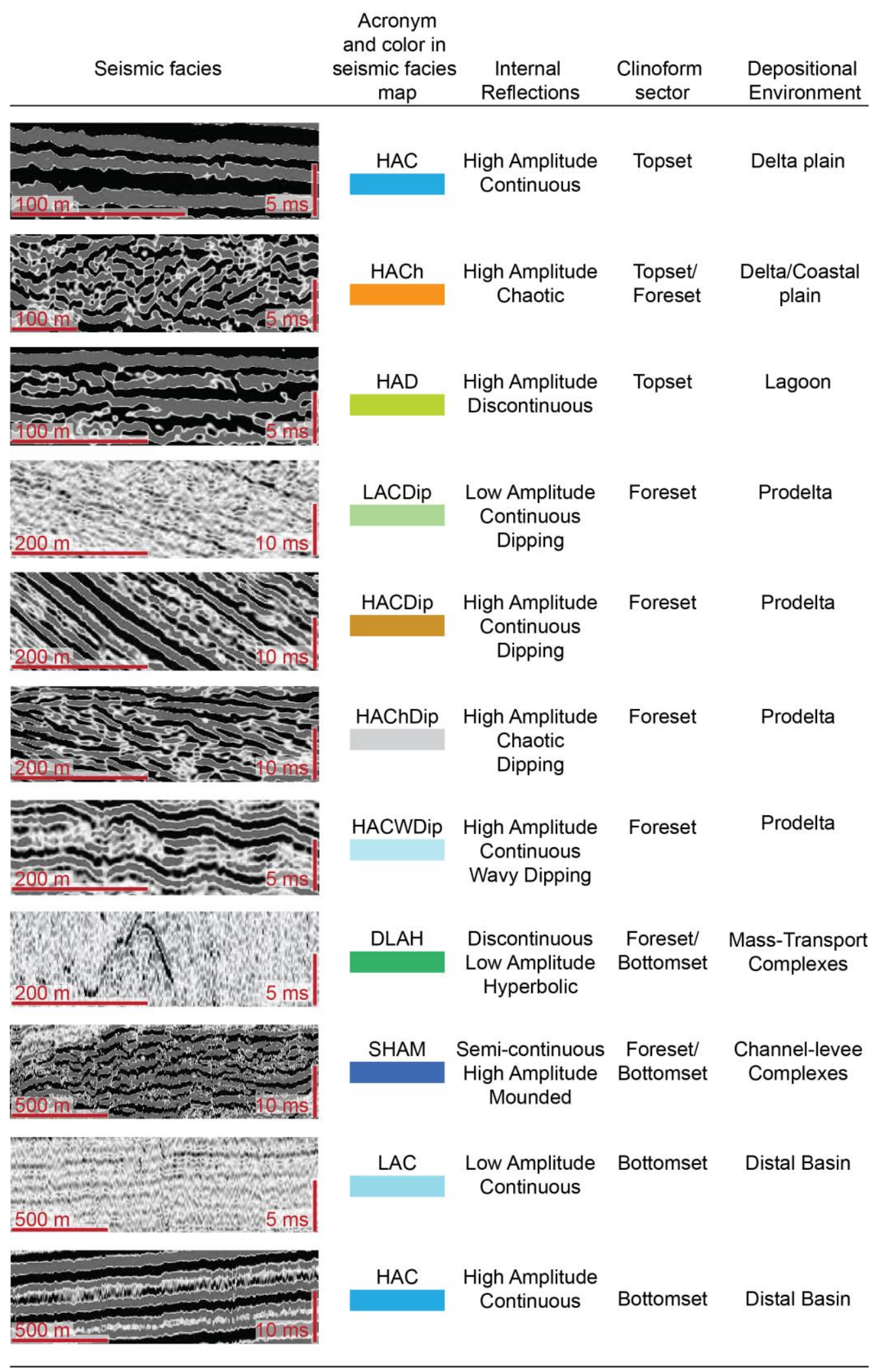

Tab. 2. Seismic facies template for the PRLW encompassing the acronym and the color legend used in the main text and in the seismic facies maps. A summarized seismic facies description and interpretation is also reported. 


\begin{tabular}{|c|c|c|c|c|c|c|c|}
\hline Clinothem & $\begin{array}{l}\text { Interval span } \\
\text { (cal.ky) }\end{array}$ & $\begin{array}{l}\text { Maximum } \\
\text { Thickness } \\
(\mathrm{m})\end{array}$ & $\begin{array}{c}\text { Volume } \\
\left(\mathrm{km}^{3}\right)\end{array}$ & $\begin{array}{c}\text { Maximum } \\
\text { Accummulation } \\
\text { Rates } \\
\left(\mathrm{km}^{3} / \mathrm{yr}\right)\end{array}$ & $\begin{array}{l}\text { Average } \\
\text { shelf-edge } \\
\text { progradation } \\
(\mathrm{km})\end{array}$ & $\begin{array}{c}\text { Foreset } \\
\text { inclination } \\
\left({ }^{\circ}\right)\end{array}$ & Depocenter \\
\hline $\mathrm{C}_{2}$ & 1.4 & 64 & 30 & 21.5 & 1.1 & 2 & $\begin{array}{l}\text { Elliptical, restricted } \\
\text { on the } \\
\text { western slope }\end{array}$ \\
\hline $\mathrm{C}_{1}$ & 2.2 & 150 & 67 & 30.5 & 5.5 & 1.9 & $\begin{array}{l}\text { E-W elongated, convey } \\
\text { the structural confinement } \\
\text { in the western sub-basin }\end{array}$ \\
\hline$A_{6}$ & 0.6 & 85 & 33.5 & 56 & 3 & 1.9 & $\begin{array}{l}\text { Elliptical in western } \\
\text { sub-basin and } \\
\text { elongated in the eastern one }\end{array}$ \\
\hline $\mathrm{B}_{5}$ & 0.4 & 78 & 23 & 57.5 & 4 & 2 & $\begin{array}{l}\text { On the western upper slope, } \\
\text { compensation compared to } A_{5}\end{array}$ \\
\hline$A_{5}$ & 0.3 & 80 & 30 & 100 & 0.5 & 1.8 & $\begin{array}{l}\text { Coalescent depocenters } \\
\text { on the slope }\end{array}$ \\
\hline $\mathrm{B}_{4}$ & 0.1 & 82 & 20 & 200 & 1.5 & 1.8 & $\begin{array}{l}\text { Elongated on the central slope } \\
\text { digitated external geometry, } \\
\text { compensation compare to } A_{4}\end{array}$ \\
\hline $\mathrm{A}_{4}$ & 1.2 & 75 & 21 & 17.5 & 1.5 & 1.6 & $\begin{array}{l}\text { On the western slope, } \\
\text { reflecting the structural } \\
\text { confinement at the toe }\end{array}$ \\
\hline $\mathrm{B}_{3}$ & 0.5 & 136 & 61 & 122 & 6.5 & 1.8 & $\begin{array}{l}\text { Coalescing depocenters } \\
\text { E-W elongated and with } \\
\text { digitated external geometry }\end{array}$ \\
\hline $\mathrm{A}_{3}$ & 3.1 & 90 & 40 & 13 & 3 & 2.1 & $\begin{array}{l}\text { Two main depocenters } \\
\text { on the slope, } \\
\text { digitated external geometry }\end{array}$ \\
\hline $\mathrm{B}_{2}$ & 0.5 & 95 & 36 & 72 & 4.5 & 1.8 & $\begin{array}{l}\text { Three main depocenters } \\
\text { on the slope }\end{array}$ \\
\hline $\mathrm{A}_{2}$ & 3.7 & 120 & 33 & 9 & 2.6 & 1.5 & $\begin{array}{c}\text { Restricted } \\
\text { on the eastern slope }\end{array}$ \\
\hline $\mathrm{B}_{1}$ & 1.0 & 160 & 44 & 44 & 3.2 & 1 & $\begin{array}{c}\text { Radial, } \\
\text { compensation } \\
\text { compare to } A_{1}\end{array}$ \\
\hline$A_{1}$ & 2.4 & 110 & 66 & 27.5 & 3.8 & 0.9 & $\begin{array}{l}\text { Radial, restricted } \\
\text { on the central } \\
\text { outher shelf }\end{array}$ \\
\hline
\end{tabular}

Tab. 3. Summary of the characteristics of single type of clinothems. 


\begin{tabular}{|c|c|c|c|c|c|c|c|}
\hline Clinothem & Pre-existing bathymetry & Depositional Patterns & $\begin{array}{l}\text { Topset character; } \\
\text { Interpretation }\end{array}$ & $\begin{array}{l}\text { Foreset character; } \\
\text { Interpretation }\end{array}$ & $\begin{array}{c}\text { Proximal Bottomset } \\
\text { character; Interpretation }\end{array}$ & $\begin{array}{c}\text { Distal Bottomset } \\
\text { Character; Interpretation }\end{array}$ & Shelf-Edge Trajectory \\
\hline & & & & & & & Retrogradational \\
\hline $\mathrm{C}_{2}$ & $\begin{array}{l}\text { MAD antiform almost } \\
\text { buried; two sub-basins } \\
\text { with similar depth }\end{array}$ & $\begin{array}{l}\text { Circular depocenter is in } \\
\text { the western sub-basin and } \\
\text { a widespread area of topset } \\
\text { aggradation on the north- } \\
\text { western shelf }\end{array}$ & $\begin{array}{l}\text { HAC seismic facies; delta } \\
\text { plain deposits. HAD } \\
\text { seismic facies confined to } \\
\text { the East; }\end{array}$ & $\begin{array}{l}\text { HACDip seismic facies; } \\
\text { muddy prodelta. } \\
\text { HACWDip seismic facies; } \\
\text { heterolithic prodelta } \\
\text { deposits locally } \\
\text { characterized by } \\
\text { crenulation features }\end{array}$ & $\begin{array}{l}\text { LAC seismic facies; fine- } \\
\text { grained basin-floor setting }\end{array}$ & $\begin{array}{l}\text { LAC seismic facies; fine- } \\
\text { grained basin-floor setting }\end{array}$ & Aggradational \\
\hline $\mathrm{C}_{1}$ & $\begin{array}{l}\text { MAD antiform expressed } \\
\text { mainly in bottomset } \\
\text { region. Deeper sub-basin } \\
\text { in the western sector }\end{array}$ & $\begin{array}{l}\text { E-W elongated, distal area } \\
\text { confined by structure on } \\
\text { southern rim }\end{array}$ & $\begin{array}{l}\text { HAC seismic facies mainly } \\
\text { in the northern area and } \\
\text { HACh seimic facies in the } \\
\text { western area; } \text { Narrow } \\
\text { (few tens of m wide) } \\
\text { isolated channels, with } \\
\text { local subdued levees } \\
\text { (bayhead deltas in } \\
\text { sheltered lagoon/estuary) }\end{array}$ & $\begin{array}{l}\text { LACDip to HACWDip } \\
\text { reflections; muddy to } \\
\text { sandy prodelta deposits } \\
\text { locally characterized by } \\
\text { crenulation features }\end{array}$ & $\begin{array}{l}\text { LAC seismic facies; fine- } \\
\text { grained basin-floor setting }\end{array}$ & $\begin{array}{l}\text { LAC seismic facies; fine- } \\
\text { grained basin-floor setting }\end{array}$ & Aggradational \\
\hline A6 & $\begin{array}{l}\text { MAD antiform expressed } \\
\text { mainly in bottomset } \\
\text { region. Prominent bulge at } \\
\text { the shelf-edge and an } \\
\text { indentation is presents in } \\
\text { the eastern sub-basin }\end{array}$ & $\begin{array}{l}\text { Circular and elongated } \\
\text { depocenters in the western } \\
\text { and in the easten sub- } \\
\text { basin, respectively }\end{array}$ & $\begin{array}{l}\text { HAC seismic facies; delta } \\
\text { plain. HACh seismic } \\
\text { facies; amalgamated } \\
\text { channel-belts. }\end{array}$ & $\begin{array}{l}\text { HACDip seismic facies; } \\
\text { muddy prodelta }\end{array}$ & $\begin{array}{l}\text { HACDip seismic facies; } \\
\text { muddy prodelta. DLAH } \\
\text { seismic facies in the easern } \\
\text { sub-basin; Mass } \\
\text { Transport Complexes } \\
\text { (MTC). }\end{array}$ & $\begin{array}{l}\text { LAC seismic facies; fine- } \\
\text { grained basin-floor setting }\end{array}$ & Progradational \\
\hline$\overline{B_{5}}$ & $\begin{array}{l}\text { MAD antiform expressed } \\
\text { mainly in bottomset } \\
\text { region prominent bulge at } \\
\text { the shelf-edge }\end{array}$ & $\begin{array}{l}\text { Two main coalescing } \\
\text { depocenters in the western } \\
\text { sub-basin extending to the } \\
\text { upper slope; compensation } \\
\text { compensational to A5 }\end{array}$ & & $\begin{array}{l}\text { HACh seismic facies; } \\
\text { Amalgamated channels. } \\
\text { HAChDip seismic facies; } \\
\text { sandy prodelta. }\end{array}$ & $\begin{array}{l}\text { SHAM seismic facies; } \\
\text { Distributary Lobe } \\
\text { Complexes (DLC) }\end{array}$ & $\begin{array}{l}\text { LAC seismic facies; fine- } \\
\text { grained basin-floor setting }\end{array}$ & Degradational \\
\hline $\mathrm{A}_{5}$ & $\begin{array}{l}\text { MAD antiform expressed } \\
\text { mainly in bottomset } \\
\text { region }\end{array}$ & $\begin{array}{l}\text { Coalescent depocenters on } \\
\text { slope, thickest in foreset- } \\
\text { bottomset area }\end{array}$ & $\begin{array}{l}\text { HAC seismic facies in } \\
\text { western area; delta plain. } \\
\text { HACh seismic facies; } \\
\text { amalgamated channel- } \\
\text { belts. Isolated incised } \\
\text { valleys with oblique } \\
\text { reflections (point-bars in } \\
\text { meandering streams) }\end{array}$ & $\begin{array}{l}\text { HACDip seismic facies in } \\
\text { western area; heterolithic } \\
\text { prodelta. HAChDip } \\
\text { seismic facies in eastern } \\
\text { area; sandy prodelta. }\end{array}$ & $\begin{array}{l}\text { DLAH seismic facies; } \\
\text { Mass Transport } \\
\text { Complexes (MTC). SHAM } \\
\text { in a restricted area; } \\
\text { Distributary Lobe } \\
\text { Complexes (DLC) }\end{array}$ & $\begin{array}{l}\text { HAC seismic facies; fine- } \\
\text { grained basin-floor setting }\end{array}$ & Progradational \\
\hline B4 & $\begin{array}{l}\text { MAD antiform expressed } \\
\text { mainly in bottomset } \\
\text { region }\end{array}$ & $\begin{array}{l}\text { Elongated on central slope, } \\
\text { compensational to } \mathrm{A} 4 \text {, } \\
\text { digitate map pattern }\end{array}$ & & $\begin{array}{l}\text { HACh, HAChDip seismic } \\
\text { facies; amalgamated } \\
\text { channels on foreset; } \\
\text { SHAM seismic facies; } \\
\text { Distributary Lobe } \\
\text { Complexes (DLC) }\end{array}$ & $\begin{array}{l}\text { SHAM seismic facies; } \\
\text { Distributary Lobe } \\
\text { Complexes (DLC) }\end{array}$ & $\begin{array}{l}\text { LAC seismic facies; fine- } \\
\text { grained basin-floor setting }\end{array}$ & Degradational \\
\hline $\mathrm{A}_{4}$ & $\begin{array}{l}\text { Western sub-basin deeper } \\
\text { than eastern sub-basin }\end{array}$ & $\begin{array}{l}\text { Confined to western slope, } \\
\text { due to strucural } \\
\text { confinement; linear } \\
\text { progradation pattern; } \\
\text { structural confinement at } \\
\text { toe of clinothem }\end{array}$ & $\begin{array}{l}\text { HACh seismic facies; } \\
\text { amalgamated channel- } \\
\text { belt deposits }\end{array}$ & $\begin{array}{l}\text { HAChDip seismic facies; } \\
\text { sandy prodelta }\end{array}$ & $\begin{array}{l}\text { DLAH seismic facies; } \\
\text { MTCs with scattered } \\
\text { distribution }\end{array}$ & $\begin{array}{l}\text { LAC seismic facies; fine- } \\
\text { grained basin-floor setting }\end{array}$ & Progradational \\
\hline B3 & $\begin{array}{l}\text { Western sub-basin deeper } \\
\text { than eastern sub-basin }\end{array}$ & $\begin{array}{l}\text { Coalescing depocenters } \\
\text { elongated E-W with } \\
\text { digitate map pattern; distal } \\
\text { area confined by structure } \\
\text { on southern rim }\end{array}$ & & $\begin{array}{l}\text { HAChDip seismic facies; } \\
\text { sandy prodelta }\end{array}$ & $\begin{array}{l}\text { SHAM seismic facies; } \\
\text { Distributary Lobe } \\
\text { Complexes (DLC) }\end{array}$ & $\begin{array}{l}\text { LAC seismic facies; fine- } \\
\text { grained basin-floor setting }\end{array}$ & Degradational \\
\hline $\mathrm{A}_{3}$ & $\begin{array}{l}\text { Western sub-basin deeper } \\
\text { than eastern sub-basin }\end{array}$ & $\begin{array}{l}\text { Two main depocenters; } \\
\text { digitate map pattern; distal } \\
\text { area confined by structure } \\
\text { on southern rim }\end{array}$ & $\begin{array}{l}\text { HACh in northern area; } \\
\text { extensive acoustically } \\
\text { transparent to chaotic } \\
\text { units up to } 15 \mathrm{~m} \text { thick } \\
\text { (amalgamated channel- } \\
\text { belt deposits); HAC in } \\
\text { eastern area; delta plain } \\
\text { sandy-silty deposits }\end{array}$ & $\begin{array}{l}\text { HAChDip seismic facies; } \\
\text { sandy prodelta }\end{array}$ & $\begin{array}{l}\text { LACDip seismic facies; } \\
\text { muddy prodelta. DLAH } \\
\text { seismic facies; Mass } \\
\text { Transport Complexes } \\
\text { (MTC) }\end{array}$ & $\begin{array}{l}\text { LAC seismic facies; fine- } \\
\text { grained basin-floor setting }\end{array}$ & Progradational \\
\hline B2 & $\begin{array}{l}\text { MAD antiforms still subtly } \\
\text { expressed }\end{array}$ & $\begin{array}{l}\text { Elongated WSW-ENE on } \\
\text { the slope area }\end{array}$ & & $\begin{array}{l}\text { HAChDip seismic facies; } \\
\text { sandy prodelta; Locall } \\
\text { parallel to wedge-shaped } \\
\text { high-amplitude reflection } \\
\text { packages pass laterally to } \\
\text { low-amplitude reflections } \\
\text { Large-scale turbidite slope } \\
\text { channel-levee complexes } \\
\text { covered by mud wedges } \\
\text { with no evidence of } \\
\text { channelization }\end{array}$ & $\begin{array}{l}\text { SHAM seismic facies; } \\
\text { Distributary Lobe } \\
\text { Complexes (DLC) }\end{array}$ & $\begin{array}{l}\text { HAC seismic facies; fine- } \\
\text { grained basin-floor setting }\end{array}$ & Degradational \\
\hline A2 & $\begin{array}{l}\text { MAD antiform expressed } \\
\text { as area of minimum depth } \\
\text { on structural map }\end{array}$ & $\begin{array}{l}\text { Linear progradation, } \\
\text { restricted to eastern slope } \\
\text { area }\end{array}$ & $\begin{array}{l}\text { HACh seismic facies; } \\
\text { amalgamated chamnels on } \\
\text { broad coastal plain }\end{array}$ & $\begin{array}{l}\text { HAChDip seismic facies; } \\
\text { sandy prodelta }\end{array}$ & $\begin{array}{l}\text { DLAH seismic facies; } \\
\text { Mass Transport } \\
\text { Complexes (MTC) }\end{array}$ & $\begin{array}{l}\text { HAC seismic facies; fine- } \\
\text { grained basin-floor setting }\end{array}$ & Progradational \\
\hline B1 & $\begin{array}{l}\text { MAD antiform still } \\
\text { expressed in seafloor } \\
\text { morphology }\end{array}$ & $\begin{array}{l}\text { Radial, compensational to } \\
\text { A1 (east of A1 depocenter) }\end{array}$ & & $\begin{array}{l}\text { HAChDip seismic facies; } \\
\text { sandy prodelta }\end{array}$ & $\begin{array}{l}\text { SHAM seismic facies; } \\
\text { Distributary Lobe } \\
\text { Complexes (DLC) }\end{array}$ & $\begin{array}{l}\text { HAC seismic facies; fine- } \\
\text { grained basin-floor setting }\end{array}$ & Degradational \\
\hline$\overline{A 1}$ & $\begin{array}{l}\text { MAD antiform strikes } \\
\text { NNW-SSE from coeval } \\
\text { shelf-edge, forming two } \\
\text { sub-basins }\end{array}$ & $\begin{array}{l}\text { Radial, restricted on the } \\
\text { central outer shelf }\end{array}$ & $\begin{array}{l}\text { HACh seismic facies; } \\
\text { amalgamated channels; } \\
\text { broad coastal plain NW } \\
\text { (Po River) and WSW } \\
\text { (Apennine rivers) of MAD }\end{array}$ & $\begin{array}{l}\text { HAChDip seismic facies; } \\
\text { channelized prodelta }\end{array}$ & $\begin{array}{l}\text { DLAH seismic facies } \\
\text { confined to area east of } \\
\text { MAD antiform, lap onto } \\
\text { southern margin of basin; } \\
\text { Mass Transport } \\
\text { Complexes (MTC) }\end{array}$ & $\begin{array}{l}\text { HAC seismic facies; fine- } \\
\text { grained basin-floor setting }\end{array}$ & Progradational \\
\hline
\end{tabular}

Tab. 4a. Summary of characteristics of clinothems and shelf-edge trajectories. 


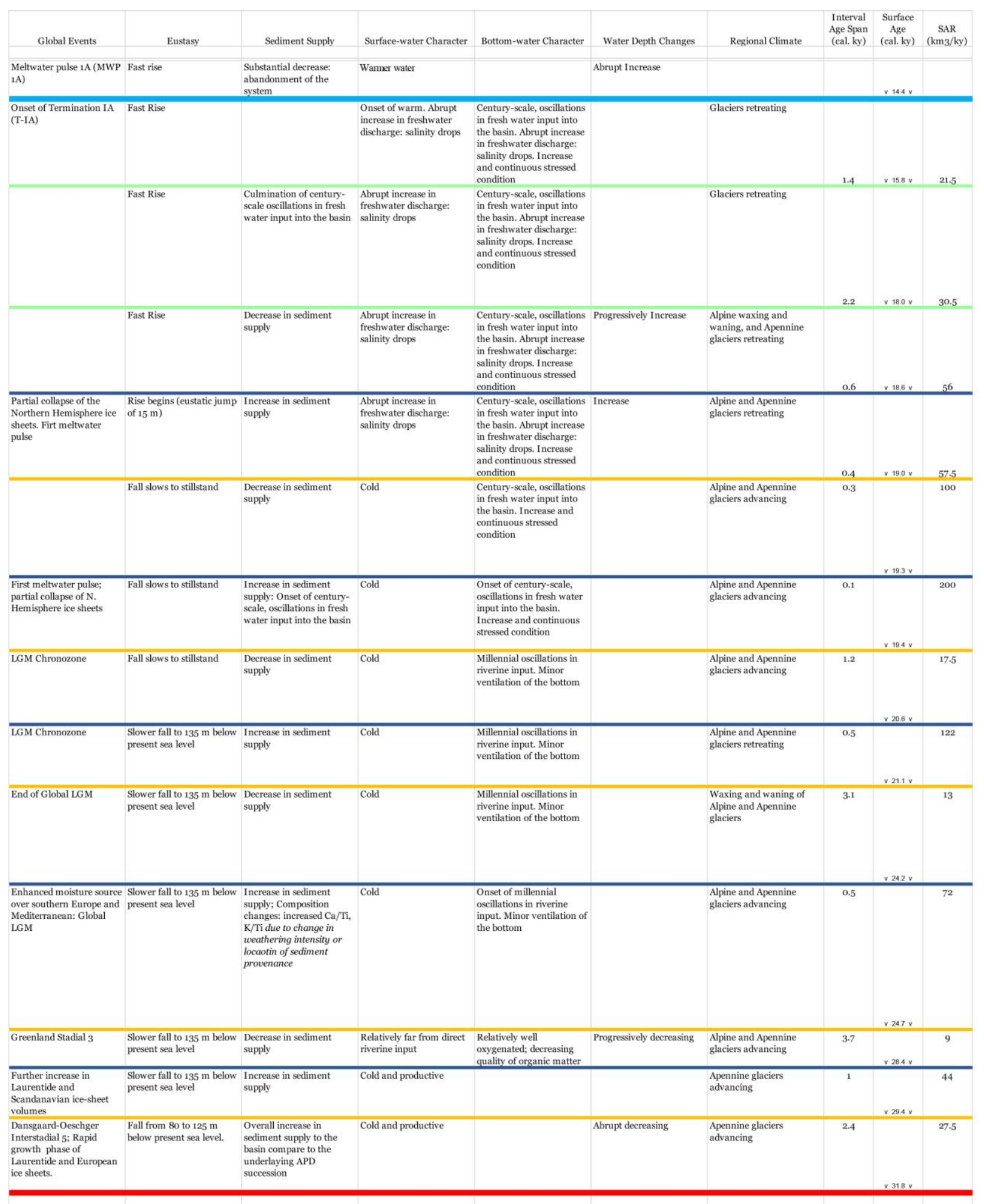

Table 4b. Summary of global events, eustacy, sediment supply, water character and regional climate regime during clinothems progradation. 


\section{SUPPLEMENTAL MATERIAL}

\section{Chronology of sediment cores}

Seismic stratigraphic correlation for the upper part of the study area are corroborated by the stratigraphy of two sediment cores acquired in the bottom and in the upper slope of the Mid Adriatic Dip (MAD). The chronology of sediment cores (PAL94-8 and CM92-43), already published by Asioli (1996) and Asioli et al. (2001), is here partially revised for the interval older than 15 ky BP (Tab. 1). For core Pal94-8 the radiocarbon dates available in literature (Asioli, 1996) were re-calibrated online with the updated software Calib 7.1. (Stuiver, et al., 2017) after a correction of $136 \pm 41{ }^{14} \mathrm{C}$-years regional reservoir effect $(\delta \mathrm{R})$ for planktic foraminifera (from the dataset Marine Reservoir Correction Database http://calib.qub.ac.uk/marine/) and an extra 200 years for benthic foraminifera according to the offset reported by Piva et al. (2008a, b). Because of the presence of reworked microfauna along with shell debris and silty-sandy mud between $\mathrm{cm}$ 230-210, the ${ }^{14} \mathrm{C}$ date at 2.28-2.32 $\mathrm{m}$ and the Neapolitan Yellow Tuff tephra (NYT, C2) at 2.08 $\mathrm{m}$ (Calanchi et al., 2008) were not considered in our age model (Tab. 1).

The age model by Asioli et al. (2001) has been adopted for the core CM92-43, in addition to the age of $14.1 \mathrm{ky} \mathrm{BP}$ for the NYT at $6.05 \mathrm{~m}$ (Calanchi, 2008; Bourne et al., 2010), while the age of the base of the core has been approximated by the physical correlation of a seismic reflection corresponding to a tephra layer detected in core Pal94-8 at 3.53 m (Y1-ET1-TM11 according to Calanchi et al., 2008). However, the origin of this and of other geochemically similar distal tephras in central Adriatic cores (Calanchi et al., 2008) has been recently revised by Albert et al. (2013), who related them to an "undefined eruptive phase" of the Mount Etna occurred between 17.64018.324 yr BP (age interpolated from Monticchio varves for the correlative tephra TM-11), that is ca. 700 years older than the Biancavilla ignimbrite (Y1). The interpolated age of this undefined tephra calculated in core PAL94-8 is ca. 16 ky BP, quite younger than the age estimated by Albert et al. (2013). If the Albert et alii tephra age is adopted in Pal94-8 chronology, the ${ }^{14} \mathrm{C}$ dating at 4.64-4.68 $\mathrm{m}$ should be rejected, as an age inversion would occur. If it is relatively easy to reject an age older 
than expected (because of reworking, bioturbation), it is more difficult to find a reason for rejecting an age younger than expected, therefore we retained the ${ }^{14} \mathrm{C}$ date at $4.64-4.68 \mathrm{~m}$ waiting for an improved definition of this undefined tephra, using this later as "guide line/reflection". Accordingly, the "tephra-bearing" seismic reflection has been tied from Pal94-8 to CM92-43 site, where it lies approximately $80 \mathrm{~cm}$ below the maximum core penetration $(10.7 \mathrm{~m})$. In Table $1 \mathrm{a}$ summary of the discussed control points is reported.

\section{REFERENCES FOR SUPPLEMENTAL MATERIAL}

Albert, P.G., Tomlinson, E.L., Lane, C.S., Wulf, S., Smith, V.C., Coltelli, M., Keller, J., Lo Castro, D., Manning, C.J., Müller, W., and Menzies, M.A., 2013, Late glacial explosive activity on Mount Etna: Implications for proximal-distal tephra correlations and the synchronisation of Mediterranean archives. Journal of Volcanology and Geothermal Research, v. 265, p. 9-26.

Asioli, A., 1996, High resolution foraminifera biostratigraphy in the Central Adriatic basin during the last deglaciation: a contribution to the PALICLAS Project. Memorie-Istituto Italiano di Idrobiologia, v. 55, p. 197-218.

Asioli, A., Trincardi, F., Lowe, J.J., Ariztegui, D., Langone, L., and Oldfield, F., 2001, Submillennial scale climatic oscillations in the central Adriatic during the Late glacial: palaeoceanographic implications: Quaternary Science Reviews, v. 20(11), p. 1201-1221.

Bourne, A.J., Lowe, J.J., Trincardi, F., Asioli, A., Blockley, S.P.E., Wulf, S. Matthews, I.P. Piva, A., and Vigliotti, L., 2010, Distal tephra record for the last ca 105,000 years from core PRAD 1-2 in the central Adriatic Sea: implications for marine tephrostratigraphy: Quaternary Science Reviews v. 29, p. 3079-3094.

Calanchi, N., Cattaneo, A., Dinelli, E., Gasparotto, G., Lucchini, F., 1998, Tephra layers in Late Quaternary sediments of the central Adriatic Sea. Marine Geology, v. 149, p. 191-209. 
Piva, A., Asioli, A., Schneider, R. R., Trincardi, F., Andersen, N., Colmenero-Hidalgo, E., Dennielou, B., Flores, J.A., and Vigliotti L., 2008a, Climatic cycles as expressed in sediments of the PROMESS1 borehole PRAD1-2, Central Adriatic, for the last $370 \mathrm{ka}, 1$ : integrated stratigraphy. Geochemistry, Geophysics, Geosystems, v. 9 (1), Q01R01, doi: 10.1029/2007GC001713.

Piva, A., Asioli, A., Andersen, N., Grimalt, J. O., Schneider, R. R., and Trincardi, F, 2008, Climatic cycles as expressed in sediments of the PROMESS1 borehole PRAD1-2, central Adriatic, for the last 370 ka: 2. Paleoenvironmental evolution. Geochemistry, Geophysics, Geosystems, $9(3)$.

Stuiver, M., Reimer, P. J., and Reimer, R. W., 2017, CALIB 7.1 [WWW program] at http://calib. org. 